Ex hibris:
K.S. Mesick.
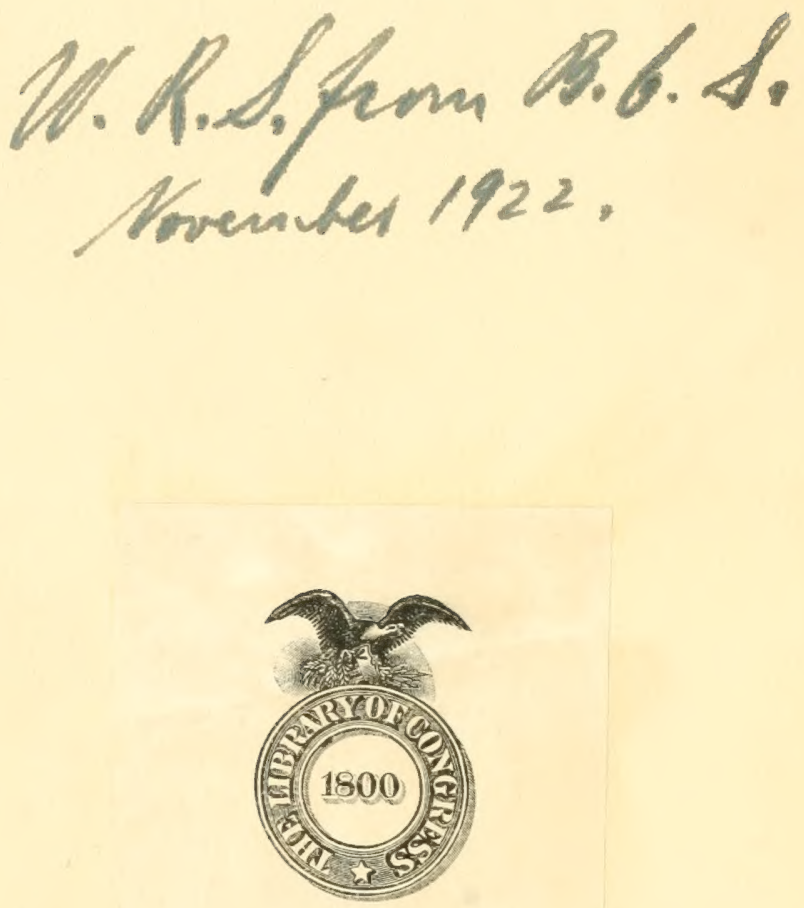

Class

Book

WALTER R. STEINER COLLECTION 





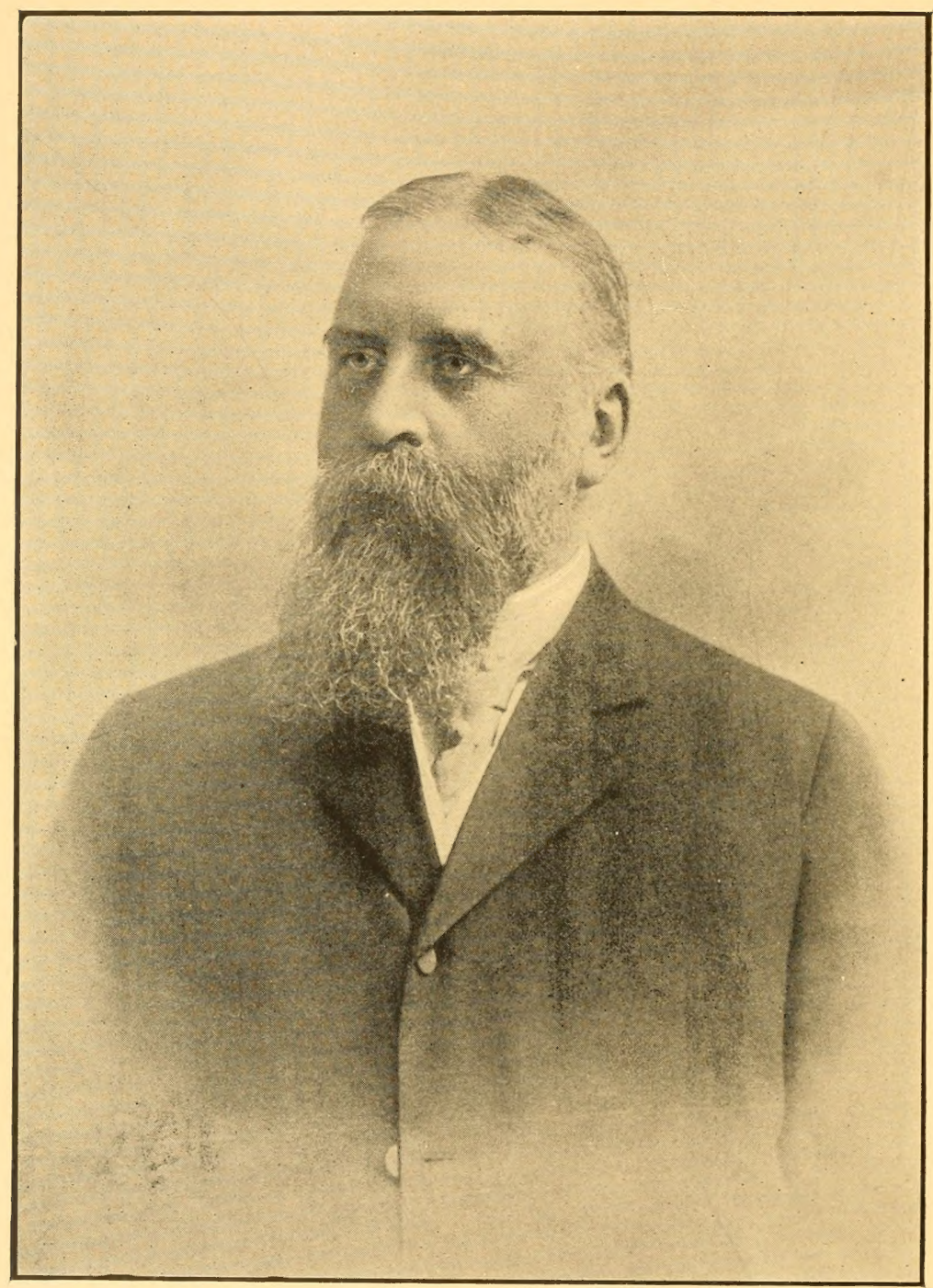

THE LATE HONORABLE PAUL ISENBERG TO WHOSE MEMORY "THE MASTER PLANTER" WAS DEDICATED BY THE AUTHOR. 


\title{
The Master Planter
}

or

Life in the Cane

Fields of Hawaii

\author{
By \\ JAMES W. GIRVIN
}

WITH NOTES BY

LEVERETT H. MESICK

HONOLULU. HAWAII :

PRESS OF THE HAWAIIAN GAZETTE CO., LTD. 


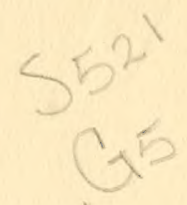

BEQUEST OF

DRR. HALTER R. STESMGE

JAN. 20, 1898

COPYRIGHT 1910

by the hawallan gazette company

LIMITED 


\section{CONTENTS.}

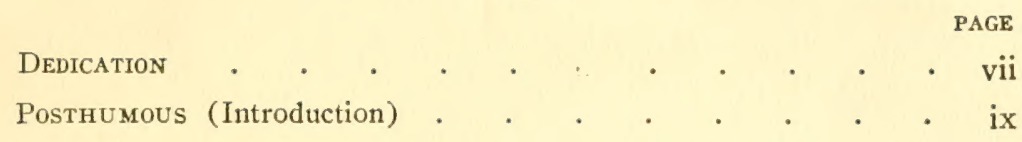

CHAPTER.

I. A New Home in a New Country, and the Introduction of the Hero . . . . . . . I

II. California in "The Days of Old, the Days of Gold, the Days of Forty-Nine" • • • . . . 5

III. San Francisco, Like Rome, Sits Proudly Upon Her Hills . . . . . . . . 8

IV. Off for the Islands-Sight of Diamond Head Compensates for an Uncomfortable Voyage . . . . I I

V. Honolulu as it was in Days of Yore-Grass Houses and Many Things That Would be Curios Now . . I5

VI. "Kansas" is Busy Investigating the Business Possibilities -Lively Times in the Days of the Whaler Man . I9

VII. Honolulu and the Churches of the Old Days-Our Hero Again at Sea, but Alone . . . . . 24

VIII. Lahaina, the Former Capital of the Kingdom-More Discouragements for the Man From Kansas . . 27

IX. Iao, the Yosemite of the Islands-Derivation of the Hawaiian Word for Law-Wailuku and its Definition . . . . . . . . . 33

X. At Wailuku "Kansas" is Advised to "Keep on Trying" in Spite of the Disheartening Outlook . . 36

XI. The Missionaries Had Trouble too-Our Hero Has Work at Last, but as "Shipped Man" . . . 38

XII. Sociability on the Plantation and at Church-"And $\mathrm{He}$ Proves to be a Jewel"- "Kansas" Making Headway 46

XIII. Some Interesting Details of Plantation Work-The Entrancing Haleakala Trig and What it Reveals . $5^{\mathrm{I}}$ 
XIV. Phases of Plantation Life-Native Language and LoreNative Divisions of Land-Dyestuffs Used by the Hawaiians . . . . . . . 58

XV. More Hawaiian Lore-Land Tenure-Tabu System-Primitive Tools and Patient Labor-Where Fell the Chivalry of Hawaii . . . . . . 63

XVI. The Hawaiians: Whence Came They and the Flora of Their Islands?-Their Knowledge of Medicine and Surgery . . . . . . . 68

XVII. Hawaiian Hospitality and Customs-Pageantry of a Royal Tour Around the Island of Oahu . . 72

XVIII. The Transformation of "Kansas"-From "Shipped Man" to Plantation Manager in Eleven Months . . 85

XIX. Hawaii Leads the World in Scientific Sugar Cane Cultivation

XX. The New Manager Makes Innovations that Startle the Silurians

XXI. Treating of the One-Time Contract Labor Conditions on the Sugar Plantations . . . . . 98

XXII. Our Hero Has a Name at Last-and an Old-Time Friend Appears with Abundant Capital . . . . IO2

XXIII. Madam Takes a Native Maiden Into Her Household, and Has an Interesting Character Study . . IO7

XXIV. Madam Interests Herself in the Natives, and Learns Many of Their Peculiarities . . . . IIO

XXV. The Happy Marriage of Kamaka Is Followed by, Alas, a Too Frequent Sequel-Piquancy of Native Cooking II2

XXVI. Mrs. Breed Learns How to Prepare and Preserve the Many Delicious Native Fruits . . . . II6

XXVII. Madam Embellishes Her Home With Native Curios that Attract the Charmed Attention of Visitors . . 120

XXVIII. The Once Obscure "Kansas" Becomes Owner and Manager of an Immense Sugar Estate . . I23

XXIX. Capital and Labor as Yokefellows-A Coöperative Scheme that Worked-Christ Quoted . . . 126

XXX. Fascinating Small Farming Applied to a Big PlantationWheat, Corn, Potatoes, Butter, Chickens, Honey . 
XXXI. "And of All That Thou Shalt Give Me I Will Surely Give the Tenth Unto Thee."-Gen. 28:22 . . I3I

XXXII. The Baleful Effects of Alcohol on the Native-The Olla

a Temperance Aid . . . . . 135

XXXIII. The Telephone Publicly Used on Maui Before It Became

General in the United States . . . . I38

XXXIV. The Primal Curse Applied to Cane Culture-Manufacturing and Marketing the Sugar . . . . I40

XXXV. Native Labor Becoming Scarce, Experiments With Many Peoples Were Made-A Political Review . . I44

XXXVI. The Chinese and Their Relation to Hawaii-Vices and Virtues of This People . . . . . I48

XXXVII. A Resume of the History of the Hawaiian IslandsFrom the Rise to the Fall of the Monarchy . . I5I

XXXVIII. Our Hero in Review Again-Experiments With Electricity-Mention of Noble Men and Women of Hawaii . . . . . . . 155

XXXIX. The Silver Wedding of the Breeds Was Celcbrated by a Liau and Hookupu of Grand Proportions . . I59

XL. The Hawaiian Language--Its Lack of Harsh Consonants Makes It Easily Adaptable to Music . . . 165

XLI. The Education of Children in the Hawaiian IslandsAn Original Perplexing Question Well Solved . I70

XLII. Religion of the Early Hawaiians and Why the People Were Ready to Receive Christianity-Evidence of Early Civilization . . . . . . $17 \mathrm{~S}$

XLIII. Debasement and Decimation of Hawaiians Due to White Refuse of Civilization Who Preceded Missionaries ISo

XLIV. Life in Hawaii and What It Stands for to People Who Call the Islands "Home" . . . . . . 183

XLV. Metal Being Unknown to the Ancient Hawaiians, the Art of Weaving Entered Into Their Every Utility I9I

XLVI. A Brief History of the Sugar Industry of the Hawaiian Islands-Sugar Cane Indigenous to the Soil . . I94

L'Envor • • . • . . . . . . . 197 



\section{DEDICATION.}

This book is most respectfully dedicated to the memory of the late Honorable Paul Isenberg.

A man who rose from the ranks in the cultivation of sugar on the Hawaiian Islands. A man whose broad sympathies reached out to the laborer of every nationality, and whose hand was always open to assist any one in distress. A man for whom the Hawaiians had the greatest respect and veneration, and who did much for their advancement by his example, assistance and advice. A man of that Teutonic race which will eventually dominate the globe from its inherent love of and maintenance of the purity of their homes and their observance of the Sabbath day.

The Author. 



\section{POSTHUMOUS.}

In the year 1906, Mr. James W. Girvin was Librarian for the Hawaiian Gazette Company. Through my connection with the same company, I became well acquainted with $\mathrm{Mr}$. Girvin, and he unfolded to me, at divers times, a mind stored brimful of useful knowledge. Any leisure moment I had I considered well spent in converse with him, especially upon affairs Hawaiian, of which he was a veritable walking encyclopedia. At that time he was working on the closing chapters of "The Master Planter," and through our intimacy I learned much of his ideas and aims in regard to the book; and evidently won his confidence, for he submitted the manuscript to me for criticism and correction from a typographical standpoint.

The press work upon the book was well under way at the time of Mr. Girvin's accidental death from drowning on the 11th of December, 1906. Of course, the work came to a sudden standstill then. Later it was decided to publish the book, following Mr. Girvin's known ideas in regard to it as closely as possible-and a large package of proofsheets and manuscript, just as Mr. Girvin had left it, was entrusted to me for disentanglement and completion. I found the closing words had not been written, or if written were not foundso I have supplied them.

A surprisingly large number of books have been published with something Hawaiian for subject matter-generally indicative of a wide-spread romantic interest in these "Isles of the Blest." Mr. Girvin's "The Master Planter," on the 
contrary, may be regarded as an antonym to romantic-exact, historical, unadorned.

It seems almost incredible that so much information could be crowded into a given space as appears in this book, and the continuity of the plot not be irreparably broken. In breaking the story up into chapters and giving them headlines, I am aware that limp justice has been done, for a single caption could not well cover more than a single paragraph in many cases-as one umbrella makes a miserable mess of covering more than one person in a rainstorm. The story in its entirety strikes me as a delightful pot-pourri, some new fragrance being encountered at almost every turn. There is something in the story for everyone. It is an encyclopedia of things Hawaiian; cross-indexed it would be almost invaluable as a hand-book of Hawaii.

The hero of the story is a composite character, exemplifying the sterling worth of the pioneers to Hawaii, who made of it the most advanced cane sugar producing country in the world. Mr. Girvin made the story of "The Master Planter" the vehicle for conveying to the public a great fund of useful information that he had gathered in many years of keen observation. The dedication is his.

A composite character-yes, but the trait given to "Kansas" of acquiring so much diversified knowledge of the people and the country, will very well fit the author himself.

Nearly four years have elapsed since Mr. Girvin's death, and in that space of time kaleidoscopic changes have taken place in affairs Hawaiian. Ordinarily, a book written four or more years ago about Hawaii would need rewriting now. Not so with "The Master Planter," however; its statements remain facts, and will have the same abiding value as has a standard encyclopedia.

Leverett H. Mesick.

Honolulu, 1910. 



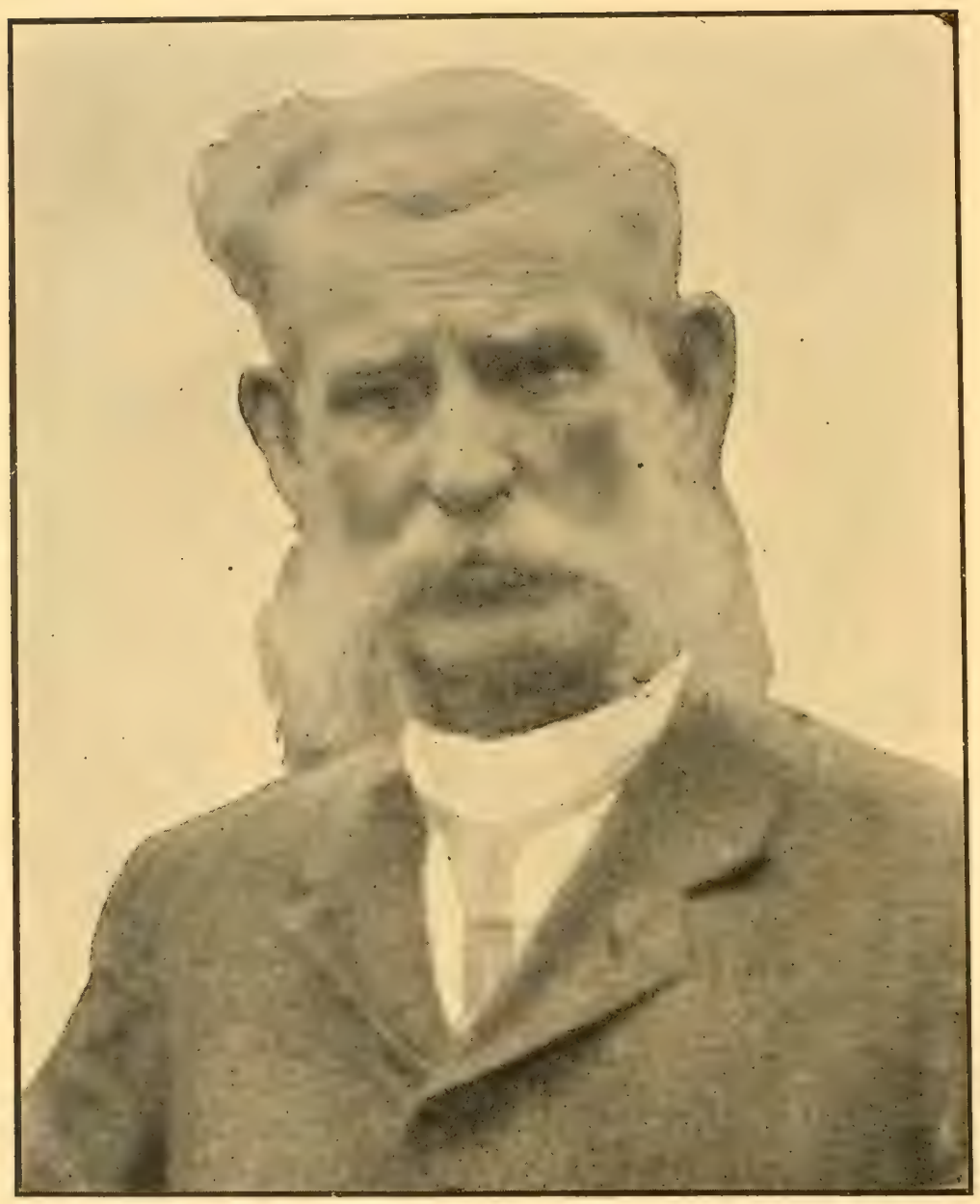

THE LATE JAMES W. GIRVIN, AUTHOR. 


\title{
THE MASTER PLANTER
}

\author{
CHAPTER I
}

A NEW HOME IN A NEW COUNTRY, AND THE INTRODUCTION OF THE HERO.

WAY back in the early sixties, in a little cabin in one of the ravines leading into Grass Valley, Nevada County, California, there lived a small family, the history of the head of which it is the intention to relate in the following chapters.

Our hero had come from Kansas, and the miners, addicted to giving nicknames, had dlubbed him "Kansas" from his hailing from that State; but in reality he had lived there only five years, having emigrated from the northern part of the State of New York. He was a tall, dark-whiskered man of thoughtful mien and reflective mood, while his wife was a sprightly little lady of a most cheerful disposition. The young couple had a child born to them in Wichita, but the little girl sickened and died, and the parents felt that Kansas could no longer be home to them, so they turned their faces westward. They had accumulated a little sum of money, and could have done well enough but for the spirit of unrest which took possession of them after "the light of the household" had gone out. They had a friend in Grass Valley whose glowing description of California, and especially of that region, determined them to cast in their fortunes and grow up with the State.

After a long and weary journey from the end of the then uncompleted railroad they arrived at their goal. Their friend was not to be found, he having drifted after the ignis-fatuus of rich reports in a distant field, as so many of the miners did. The surrounding country pleased them, and at this season was covered with innumerable species of wild flowers such as they had never seen in the east. Although an horticulturist by study and profession he saw colors such as he had never seen before. Brown, 
green, and drab lilies growing wild, yuccas ten feet high covered with a cloud of iridescent bells, flowers whose brilliancy could be matched nowhere on this mundane sphere, and the whole surface of the undulating country clothed with a carpet of small flowers to even name which would require chapters. The climate was invigorating and the scenery grand beyond description. They decided to settle there. His occupation had been that of gardener, and he quickly determined that there was more money to be made in supplying the various neighboring mining camps with vegetables than in gold digging, and the income would be more certain.

An old man who had acquired a large tract of land was pleased to give him as much as he would cultivate for a nominal share of the products. A rough little shanty, abutting a ridge, went with the claim and was to be their future home. It was sheltered beneath the umbrageous branches of one of the grand old liveoaks which dotted the plain and hillsides. Here the young couple proceeded to make their home with as much cheerfulness and unanimity as the birds which built their nests amidst the leaves of the perennial tree which covered them. Little by little they gathered around them the necessities of life and for home comfort. Women were comparatively scarce in that part, and many of the miners made a detour from the highway, nominally to ask for a drink of water, but in reality to see the little birdnest with the Eastern robin in it.

Quite a number of the miners succeeded in obtaining the privilege of taking their meals at Madam's table, for which they gladly paid fifty per cent. more than they could have lived for at the mill boarding house. During the summer the table was spread under the shelter of the shady live-oak branches, and by winter a fine commodious addition had been added to the house. The homemade bread, butter, and buttermilk were luxuries to be had nowhere else, and the refining influence of a good woman was appreciated by those who were permitted to enroll themselves as of "Kansas's" household. His cows, chickens, eggs and gardentruck had a market limited only by the supply he was able to produce. He found the soil to be excellent, and that everything planted produced abundantly. By hauling some of the pulverized tailings from the mill and spreading it on the adobe soil he supplied to that clay its corrective, and the yield of beets, onions, potatoes and regetables was something marvelous. Some of his 
mangel wurtzel beets, planted for cow feed, weighed more than 150 lbs., and pumpkins grew so thickly that it was possible to walk over a field by stepping from one pumpkin to another.

There were some drawbacks, however, in the form of vermin. The air teemed with birds and insects and the ground had its myriads of gophers and squirrels, while from the plain came up the cotton-tail and the jack-rabbit to devour anything green. His strawberries, raspberries and other small fruit were preyed upon by the quail, catbirds and others, whilst his melons were sought after by badgers and other quadrupeds. Deer frequently came down at night and revelled in his corn and cereals.

Game was plentiful, and grizzly and brown bear threatened not only to decimate his pig-pen and calf-yard and honeystands, but to make life a burden. Indians straggling through the country frightened Madam, but were harmless. The table was rarely without venison, quail, pheasant or other game. The miners united with "Kansas" in pursuing the bears, mountain lions and fur-bearing feræ, and they became somewhat scarcer. Madam was sorry sometimes to see the song birds destroyed, but self protection is the first law of nature. In the early mornings, and at even, the air would be redolent with harmony from innumerable meadow larks and thrushes. Every bush in the chapparal on the hillsides had its colony of bird life.

The long table out of doors was frequently surrounded with men, who, judged by their rough appearance, were Ali Baba's forty thieves, while from their conversation, which was extremely edifying, their antecedents could be discerned. Naturally, from their occupation as miners, geology and the origin and formation of the globe was frequently the theme of debate and conjecture. Still there was no subject which was not discussed. Sometimes politics was introduced, to the disgust of Madam, as that subject led to wrangles from which neither edification nor profit was to be obtained. The men were from different parts of the East and naturally disagreed. Some were Southerners, one of them having brought two slaves with him who were regularly paying him their wages on a promise of emancipation on receipt of the cost of bringing them out and to their value as estimated at home.

"Kansas" had been one of thr radicals in his late place of residence, and it is well understood that in the State of Kansas there is to be found no one who does not take an active interest in everything pertaining to politics. The throes at the birth of that 
State had threatened to dismember the Union, and the war which was then raging was considered one of the outcomes of it. Madam almost decided to discontinue keeping boarders, and eventually succeeded in reducing the number to a few who could control themselves in the heat of political debate. Their Chinese cook and laborers appeared to be thoroughly at home in this strange land, and when Madam undertook to give them lessons in English on Sunday afternoons she had a class which appreciated her kindness. 


\title{
CHAPTER II
}

\author{
CALIFORNIA IN "THE DAYS OF OLD, THE DAYS OF GOLD, THE DAYS \\ OF FORTY-NINE."
}

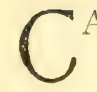

ALIFORNIA, covering ten degrees of latitude, has surprised the people of the United States not only in its mineral resources, but in the fertility of its soil and the exuberance of thought of its inhabitants. Within those ten degrees of latitude, which by the way have proven in the Old World to have contained the cradle of the human race, and today hold the ruins of the world's earliest civilization, can be found a greater variety of the fauna and flora of the globe than in any other part.

The appreciation which the early settlers had of its marvelous climate, scenery and possibilities was indelibly stamped on it by the manner in which they named different localities. We find Paradise, Banner, Golden Gate, Silver City, Loveland, Woodland, Greenville, Bloody Gulch, Dead Horse, Grizzly Flat, Antioch, Acme, etc., etc., and the earlier Spanish settlers used up the whole calendar of Saints in naming the different points and localities in this great State, and finally in despair at the paucity of the calendar dubbed a bay Todos Santos (all Saints). Rough men, made hardier still through their contact with the Plutonic rocks from which they obtained the auriferous metals, named many places in accord with some obstacle which attracted their attention, as Whiskeyville, Dead Man's Gulch, Eureka, Sacramento, etc.

Drawn thither by the prospect of acquiring speedy wealth from mining, people of all grades of intellectual culture and from every nation under the sun can be found. It was a common thing to find men who could speak many languages as well as men who were conversant with the classics. Although a little book of fifty-two leaves was the most common, the man who found his intellectual treat in the Bible, Shakespeare, Horace, Virgil, or some of the scientific works was freely met with. All appeared equally rough, and it was only on close inspection that the diamond was discovered. Rough in appearance, wild in 
action, and coming from different parts of the States and of the world, still men of similar thought and inclinations naturally drifted together, as the magnet will draw particles of iron from sand made up of grains of disintegrated rocks of every class.

Men of every profession and trade made up the army which crossed the plains in search for gold. Amongst them there naturally predominated those who had followed farming or manual labor. These were observant of the natural facility of the soil to produce crops, and also of the ready market for the products. The claims made by the Spaniards prevented much of the land from being acquired by these agriculturists, but little by little many little holdings were acquired and small orchards and gardens began to be cultivated.

Our hero's small ranch appeared like an oasis in a desert, for California in the dry season has a most desolate and burnt-up appearance. He had brought out a small stream from the cañon (or canyon) above the premises, and all shrubbery and trees as well as the vegetables planted by him throve remarkably from the supplied water.

"Kansas" had excavated a cellar into the hillside, against which the house abutted, and had put down a drive well therein from which a deliciously pure water was obtained. Having procured an olla, one of those earthern vessels which the Spaniards had introduced into the country, and which the Indians made from clay and carried about for sale, and which on account of its porosity materially aided in cooling the water, he hung it to a limb of the live-oak. Thirsty travelers from all directions debouched from the main road to get a drink of this cooling water, and gradually the place became so central that when necessity for establishing a postoffice was felt, "Kansas" station was fixed upon as the most convenient for the miners in that whole region.

Our young couple prospered in every way, and not only made money from their own exertions, but, having grub-staked several prospectors, "Kansas" was fortunate in being able to sell out of several claims to good advantage. The healthiness of the climate was remarked, and they had enjoyed life as much as could be exfected from the isolation Madam was compelled to endure. To make money alone was not the height of their ambition, and "Kansas" did not feel that it was justice to his wife to seclude her in a mountain camp. After four years residence in Grass Valley he determined to move to San Francisco. During their 
residence in the mountains a boy and a girl had been born to them, which materially added to the mother's cares. He had acquired the quarter section, which he first rented from the old ranch owner, and now disposed of his holdings and the fine site for a good round sum. His intention was to either establish himself as a florist in San Francisco or engage as a scenic gardener with some of the wealthy nabobs of that metropolis. 


\section{CHAPTER III}

SAN FRANCISCO, LIKE ROME, SITS PROUDLY UPON HER HILLS.*

"V ANSAS" had made a study of the science of agriculture from the best works to be obtained, and was thoroughly familiar with the requisities of different soils in the matter of correctives, manures, and fertilizers. Being farmer-born he appreciated the lectures at the agricultural college he had attended, and during his practice of several years in Kansas and in California he had the opportunity of testing many of the teachings he had received and also of watching his own experiments. He knew that for the best results from planting it was as necessary that plants should have their proper plant food as that animals should have food that would digest. Also, that it was as requisite that this food should have reached its correct stage of fermentation to promote assimilation before being absorbed by the rootlets of the various plant-life.

Being somewhat of an artist and designer, he had drawn many plans of flower gardens adapted to the embellishment of homes of lovers of beauty in that line. Some of the colored designs which his portfolio contained were models of carpet gardening, labyrinthine walks bordered with vari-colored plants, which enclosed beds of brilliant flowers. Many happy hours he and his wife spent in designing parterres of beatififul flowers, grasses, border plants, etc. This was done as much for pastime as to have on hand a collection of designs or patterns as guides in selecting the most appropriate for different situations. One of his ambitions was to obtain the supervisorship of some large grounds where, with a free hand, he might make a showing of what esthetic cul-

\footnotetext{
* She "sat," for a large part of the city of San Francisco, including practically all of the business portion, was destroyed by earthquake and fire following it on the 18th and 19th of April, 1906. A monetary loss of $\$ 400,000,000$ was caused; and many human lives were lost, the exact number will never be known. Phœnix-like the eity has risen from its ashes, and now, 1910, in about four and one-half years after its destruction, is better built than the old city was.
} 
ture could effect. He did not overlook the immense market which the love of the masses for cut flowers and potted plants afforded, but kept that in the background, as it were, as a matter of secondary consideration.

Arrived in San Francisco he proceeded to endeavor to enlist some of the wealthy property owners in a scheme to ornament their homes, he to undertake the supervision of a number of such. He recognized the natural possibilities of the city, on account of its being built on many hills, for ornamental gardening. Although the soil of the sand dunes of the whole peninsula on which the city was built was poor, that was a matter which might easily be corrected; and the lay of the land was much better for scenic effect than would be that of a level country. After meeting many of the property holders and showing them his plans he found, and was surprised at it, that so few cared for the matter, and all were satisfied with such slight improvements as their wives might make. A few gave him encouragement, and thought such a scheme of coöperating in maintaining a trained gardener as somewhat in advance of the present system,--but there were not enough to warrant his undertaking the work.

He abandoned the idea, and turned his attention to establishing a garden, one of the New Jersey style of florists' gardens, wherein he could raise flowers and potted plants for sale. On looking into this field, however, he found that it was pretty well worked and the city fairly supplied. Real estate and rents were high and he could not locate himself. Turning his attention to the humble yet lucrative work of raising vegetables for the market, he found this was very largely done by Italians on the outskirts of the city as well as by farmers on the Sacramento and San Joaquin rivers, great quantities coming in by steamers every morning. Without much capital he knew he could not compete in supplying the city markets, and he would be again burying his wife in the country.

He then turned his attention to other means of providing for his family, and in his peregrinations became quite familiar with the geography of the city and its environments. He tramped over Russ Hill, viewed the city from Telegraph Hill and Black Point, and made the tour of the Presidio and Fort Point. No observing person can survey San Francisco and its noble bay and fine waterways without arriving at the conclusion that it will be the theatre of an immense commercial future. Looking at it 
from an artistic standpoint, there is no part of the world that is more beautiful. From Telegraph Hill, as the observer turns on a pivot, the vista, on a clear day, is truly magnificent.

Apparently the atmosphere of central California is as pure as in any region on the face of the globe, for the eye can discern points at great distances. San Francisco has been endowed with many advantages, and if man will only make use of them it will assuredly be the center of commerce which will control the trade of the countries which border on the Pacific. The great freshwater ways flowing towards it will force on her the wealth of the immense agricultural provinces watered by them. The great numbers of men who were attracted to the State by the discovery of gold, were largely composed of men from the rural walks of life. These quickly discerned the great wealth the State had in her agricultural lands, and soon abandoned the search for the auriferous metals.

Many of the large Spanish grants were subdivided and the cattle driven off, and the lands turned into orchards, vineyards and farms. In early days most of the foodstuffs was brought around the Horn, or from Chili, or the islands of the Pacific. In a few years the Eastern immigrants had foodstuffs to export, and agriculture began to vie with mining for the first place.

Grand as was the outlook for the future city, our hero tried in vain to place himself. In his travels or tramps along the waterfront he frequently saw vessels discharging cargoes of sugar and molasses, and tropical fruits, from the Sandwich Islands, and talked with the officers about the prospects there for a working man. Although he received but little encouragement from them, he concluded that a country which produced such large quantities of sugar might be made to yield a living, at least, to a couple who were willing to work.

He and his wife made as much of a study of the Islands as was possible from the few descriptive works on Hawaii to be found in the public libraries, and decided to go there and try their fortunes. It was a leap in the dark, but they had ample means to return if the country should not prove satisfactory. 


\section{CHAPTER IV}

OFF FOR THE ISLANDS-SIGHT OF DIAMIOND HEAD COMPENSATES

FOR AN UNCOMFORTABLE VOYAGE.

T O save their little hoard they resolved to economize in every way, and to that end engaged passage in the steerage on a small bark which made regular trips to the port of Hono-

lulu. They had never traveled on the sea before, and looked forward to the trip as to a picnic when one camps out for a season. They laid in a little stock of provisions and comforts, and took up their quarters on board the evening before the vessel was to sail. Early in the morning the vessel was towed to sea, and after the bar was crossed they began to realize the immensity of the ocean. Their quarters were rude and uncomfortable; it was cold and miserable, and, to add to the discomfort, all four were wretchedly seasick. The great strong man seemed to be the most affected, and could not help his family. Fortunately, a kindly lady in the cabin, who was an islander, a daughter of a missionary, and a good sailor, had noticed the children and devoted herself to their comfort.

For three days the sky was overcast, and alternate showers and squalls added to the wretchedness of the voyage. Many a time, during those three days, did the miserable couple wish they were back on terra firma. Then came the genial weather and sunshine, together with the trade winds, and they began to feel better and enjoy the trip, and help themselves. They began to really enjoy the voyage, and sitting on deck they learned very much of the islands from those who were returning residents. Not having had the opportunity in San Francisco of meeting islanders, their information was indeed very meager. From the missionary lady they heard much of the hardships of the early mission, and of the success in converting the natives to Christianity. Also of the ravages caused to the aboriginal population by the introduction of disease and rum by sailors. Much also of the character of the natives, and of their innate hospitable reception of aliens from any land. 
From the stories told, a very good impression of the natives was obtained. "Kansas" became quite intimate with a man who had passed several years on the islands, and who described the cultivation of sugar and told of the opportunities for investments. It appeared that only a large capital would warrant any one in going into that industry, and from his remarks it appeared, also, there was no other that a white man could make a success at.

When fifteen days out, the island of Maui was sighted, the captain saying that the mountain thereon, Haleakala, was ten thousand feet high, and visible from a great distance. Sailing along they passed the island of Molokai, and had a fine view of its precipitous mountain range. Then the island of Oahu approached, and the beautiful valleys thereon opened up one by one with enchanting beauty. Rounding Diamond Head, the town of Honolulu, together with the forest of masts in its harbor, appeared. The great forest of cocoa palms which fringed the shore, together with the wealth of foliage of lesser umbrageous trees, created a pleasing impression of the tropical beauty of the place.

From the deck of the vessel the panorama presented was a most charming one. The difference between the gloomy, forbidding and sunburnt coast of California, which they had just left, and the verdure-covered peaks of the Island of Oahu, was like the awakening from a dismal nightmare. With an artistic and almost prophetic eye our hero could see a brilliant future for Honolulu. Diamond Head, which they had just rounded, stood out in bold relief, and no one asked why it had been called Diamond Head, as that was the natural name for it, its clear-cut, precipitous sides reminding one more of the facets of a cut diamond than of anything else. Far ahead of the ship could be seen another range of mountains similar in appearance to that at the rear of the city. At the margin of the neck of land which connected the two ranges lay a loch, called Pearl Harbor, upon whose smooth waters the sun glistened. Many valleys, whose sides were covered with verdure of different shades, opened towards the sea, giving promise of enchanting drives and points to lure the sightseer.

Although our hero and his family had forgotten the hardships and misery of the first part of the trip, and were enjoying to the full the balance of the voyage, they, with the cabin passengers, were glad to get ashore.

"Kansas" was a brave man, and was not intimidated by what 
he had learned of the unlikelihood of succeeding on the islands. Although the impression he obtained was that there was a great distinction made between rich and poor, and that the prospects for a poor man were not bright, he did not apply it to himself. He had never felt poverty, and had always been able to make provision for his wife and family. In Kansas and California, they were not considered poor, the masses being of their own class. He had been well educated in the public schools, had been a year at an agricultural college and had taught school two winters before he had met the young woman who had agreed to take him for better or for worse, and they had gone west. Now they were to live in a country where there was a marked distinction between those who had the possession of money, accidentally or otherwise, and those who had none. This they could not realize. It did not disturb them very much, as they had within themselves all that was necessary to make life happy, and they merely sought the opportunity to make a living by their own exertions. Also, they were in a foreign country, which they soon found out, as their baggage was thoroughly examined by customs officers, and "Kansas" was compelled to pay two dollars for a permit to land. There were no hotels nor hotel runners, and they hired a push-cart to carry their effects to a lodging house in a part of the city where rents were low.

Everything seemed strange to them, and in some respects the city appeared like a frontier town. Half naked kanakas carrying sticks over their shoulders, with bundles of dried grass or calabashes filled with poi (the staple of life of the Hawaiian), shocked the woman. Numbers of Chinese thronged the streets, and carried on innumerable dirty looking restaurants and small shops. The narrow, crooked and winding streets, lined with houses of all descriptions, from those built of rough coral slabs, to frame structures of all imaginable styles of architecture, and with overhanging verandas, gave one an impression of a place which had grown up, and not been laid out, as the majority of American towns and cities have been. Many rude sailors thronged the streets, forming the crews of the innumerable whaleships in the harbor. Their actions and language, and the heedlessness with which they rode through the city on horses, alarmed our newcomers. The food at the restaurants was good, but they soon found it inconvenient to take the children out three times a day 
along the narrow, thronged and ill-kept sidewalks. Finally they obtained lodgings at the Sailors' Home, a fine building which was kept by a delightful old American lady, who seemed like a mother to all. 


\section{CHAPTER V}

HONOLULU AS IT WAS IN DAYS OF YORE-GRASS HOUSES AND MANY

THINGS THAT WOULD BE CURIOS NOW.

$\AA^{\mathrm{s}}$

$S$ they got opportunities to see more of the city, they found that there were many homes of refinement situated on the main avenue leading up Nuuanu Valley. These were set well back from the street, and were surrounded by a wealth of tropical foliage, and gave the tourist an impression of home and comfort. They climbed Punchbowl, a hill 500 feet high in the rear of the city, from where they obtained a magnificent view of the city, its harbor, and the whole surrounding country. The spires of churches loomed up through the foliage which covered everything.

The prospect was entrancing. Grass houses of the natives looked like last year's haystacks, but were by no means numerous, they having been superseded largely with frame structures. Cocoa palms here and there had prominence over the lower forms of shrubbery, and bore the appearance of frayed-out umbrellas. A glamour seemed to have possessed cur travelers, for they were charmed with everything in view. They were reminded of the saying of one of the passengers, "that any one who lives on the islands for a time will assuredly come back." The balmy air, the evenness of the temperature, the geniality of expression on the faces of all the conglomerate inhabitants, and the pleasant surrounding,s must be chargeable with this restful, homelike impression.

The harbor was small, but seemed adequate for the business of the port. Business appeared to be brisk, and a spirit of contentment possessed all with whom they came in contact. The natives, especially the women, were decked out in the most brilliant colors of silks and prints. Both men and women wore leis (wreaths) of flowers or ferns around their hats, the latter being principally home-made from cocoa or other palm leaves. It was quite common to see bare feet peeping from under silk gowns, probably from the comfort of going barefooted. Carriages were not very 
numerous, although drays for carrying merchandise were quite common. It was a frequent sight to see natives seated on push carts, together with their household effects, being moved from one part of the city to another. Gangs of prisoners working on the street, in parti-colored garments, under the charge of a turnkey, were continually on the move. It was also the rule to hire out prisoners to private individuals, as gardeners or chore-men. Amongst the prisoners a few white men were seen, but they were principally natives or Chinese. Evidently, there was no penitentiary where prisoners could be kept employed within walls at the manufacture of merchantable wares, as in cities on the mainland. Uniformed native police and soldiers appeared to be quite. numerous.

The meat and fish markets seemed to be well stocked and well patronized. It was quite a treat to visit the fish market, where both were sold, and watch the manner of selling and delivery of the wares. The market was always interesting, from the great variety of curious and beautifully colored fishes, varieties which were strange to the markets on the mainland. To note how quickly a native salesman would wrap up fish in a couple of leaves, which afforded a handle for carrying the package and at the same time a vehicle, dish, or mode for cooking the same, when the buyer had arrived at home.

On visiting the houses of natives, who always welcomed the stranger, our travelers were surprised at the simplicity of the domestic arrangements. To make a fire in a small hole surrounded with stones and place a saucepan over it, as the miners did, was the only way (excepting the cooking of taro) what cooking they did was performed. Many kinds of fish were eaten raw, but this did not have the repulsive features about it that one wouid expect. When properly cleaned and cut up in lumps there was no blood and gurry, and on trying it they found that it was as delicious as raw oysters, and equally digestible.

It was quite common to see natives carrying coffee or tea-pots from Chinese restaurants, somewhat the way some of our people "rush the growler" in the East. Saddle horses appeared to be very numerous, and men and women rode equally astride. It did not appear to be unbecoming for women to ride astride, as they had invented a garment for the purpose. It was wrapped around the hips and extended down the inner side of the leg, and was held in place by the great toe in the stirrup. Generally 
they were made of the most brilliant colors to be had, and a cavalcade of native women galloping through the streets made a very pretty sight.

For a tropical country the markets afforded very little variety of fruits. Oranges, breadfruit, ohias (mountain apples), bananas, and a few guavas, were all that was noticeable, whereas in the West Indies a hundred kinds of fruit would be offered.

There appeared to be considerable drunkenness on the streets, and even amongst the native men and women, although it was a serious misdemeanor to furnish liquor to them. The police appeared to be quite active, and on the slightest manifestation of inebriety in a sailor, he would be taken to the station house, from whence he did not depart until he contributed his share towards the support of the government.

A small foundry and machine shop seemed to be very busy turning out sugar machinery, but it was said that most of that used on the islands was imported.* There was a very large fleet of small schooners which plied between the islands, and one steamer, although for speed the schooners were preferable. Great quantities of produce came in regularly, and the wharves presented a busy sight where these small craft were discharging their cargoes of oranges, rice, corn, pigs and cattle. The natives were great travelers, and the decks of these small vessels appeared to be as full of passengers as it was possible.

Large quantities of lumber were being piled up along the wharves, and the change from grass houses to frame buildings had set in all over the islands. There appeared to be no attempt to export tropical fruits, nor in fact anything but sugar, rice, and whalebone and oil. The discovery of rock oil, or petroletm, and

* This is one of many industries in which Hawaii has forged ahead Wonderfully, ever abreast of the world's progress. The Honolulu Iron Works is not only now manufacturing practically all the sugar mill machinery used in the phenomenally-enlarged sugar industry of the group, but is building and erecting mills in Mexico and the Far East in competition with the world. At this time (1910) the biggest sugar mill in the world is being built at the Honolulu Iron Works for the Philippines and will be in operation in 1911; by biggest is meant the largest rollers, not the capacity of the mill. A mill in Cuba is said to have the greatest output capacity, with our own Puunene, on Maui, second. Nearly two dozen of the Hawaiian mills are to the credit of this wide-awake concern. An order is now in hand, from Japanese sources, for the sixth big mill for Formosa. 
the numerous uses it could be applied to in illuminating and for machinery, was said to have reduced the price of whale oil, and that industry would cease. The merchants talked over the matter, and it did not appear as if there was anything which could take its place.

The rock-bound coast of most of the islands, and the lack of harbors, Honolulu being the only true harbor in the archipelago, gave the impression that the cultivation of sugar must be limited. Coffee, cotton and tobacco had been tried, but for various reasons success in any of them was not prognosticated. The district of Kona, on Hawaii, produced a magnificent, aromatic coffee, but it was said that the scarcity of hands for picking it and the low prices of Central American and Brazilian coffee, with which it would have to contend in the market, would prevent the industry from ever assuming large proportions.

"Kansas" tramped the streets and made numerous acquaintances, and his Yankee style of making inquiries into every possible matter was remarked. He studied the maps of the different islands, and was given all possible assistance in the survey office. From the surveyors, who had tramped over the different localities, he learned very much. 


\section{CHAPTER VI}

"KANSAS" IS BUSY INVESTIGATING THE BUSINESS POSSIBILITIES-

LIVELY TIMES IN THE DAYS OF THE WHALER MAN.

$\mathrm{T}^{\mathrm{n}}$

HE principal food of the natives was taro (arum esculen$t u m)$, and it was also used in every home. He studied the cultivation of it, and found that it was raised in patches which were diked about with earth or stone embankments at great expense. It was raised in water, that is, after the patches were dried up and dug up and the tops of the plant ser in mud the water was turned on and it was kept flooded until nearly ripe, probably I2 or I4 months, and then pulled and the tops cut off for future planting, and the roots sold in sacks or made into poi, a paste made by washing, cooking and mashing the taro and mixing with water. It was a very wholesome food, and our travelers liked taro in any form, either as plain boiled, baked, made into cakes, or as poi. "Kansas" soon saw that he could not compete with the natives in the cultivation of taro, as it required weeding and working as well as any other vegetable, and this could only be done by wading in mud, the best way of doing which was the native style, i. e., naked, with a breech clout on.

He saw the love of all classes for flowers and knew that he could make a success of that business, although the natives were very good natural gardeners, and in their little patches raised great quantities. He tramped up Nuuanu Valley, where a small sugar plantation was being carried on. In conversation with the owner he was proffered work, but at a very small salary. When he told that he had a wife and two children to support, the planter said they had no accommodations for a white woman on the place, and "Kansas" could not live on the pay.

He went over the Pali, the great precipice which was said to be the scene of Kamehameha First's last battle in subjugating the islands, and visited two sugar estates on the Koolau side. At both places he was nicely received, and at either of them he could have obtained work, but neither of them had accommoda- 
tions for a white woman, and the pay offered was very small. Still, the more he saw of sugar the more he was interested in its culture, and was sure that he could make a success of it if he could only catch on. He and his wife talked over all matters that he learned in his peregrinations, and she could not understand why there should be much objection to a man who had a family.

They felt that they had made a grievous mistake in coming to the islands, but she saw his inclination to the sugar industry, and they determined that he should see more of the country before deciding to return to California. He had taken note of the Chinese gardens, which as a rule consisted of several taro patches, dried up and cultivated by hand, as there was no room for a plow. They paid very high rentals for these lands, especially those near to the city limits, and they packed their produce from door to door, in baskets carried on long sticks or poles across the shoulders. He always had admired the indefatigable industry of the Chinese, but never thought to be brought into competition with it. They worked very hard, and even in the night might be seen watering their little vegetable gardens. There was no room for him in the gardening industry, which he so well understood. He saw the love of flowers and greenery displayed in the homes of the foreign population, and knew that he could make money at potting plants and ferns,--but the sugar cultivation was what he wished to get into.

$\mathrm{He}$ and his wife endeavored to see all they could of Honolulu, hut there were not many public conveyances. Occasionally he induced an old skipper to take his wife out in a rambling old chaise, which looked as if it had come out in the ark, and that Noah, himself, just over a drunken spell, was driving it. It was a good deal better than staying at home, as walking in the tropics, to one not used to it, is very trying. Saddle horses were very numerous, and he induced his wife to learn to use the saddle.

The old lady at the Home gladly took charge of the children at times, and they were enabled to get about and see somewhat of the surroundings of the city. They climbed to the top of Punchbowl, from where they obtained a magnificent view of the whole adjacent country. Far to the west a charming vista presented. An immense field of emerald, at certain parts of which the sea was enclosed, forming lagoons, appeared to afford agricultural possibilities. This great slope was well watered by 
numerous streams from the range of mountains which was the backbone of the island of Oahu.

On riding over these lands he found they were only cultivated in the valleys or near the margin of the lagoons, and was told that the balance of the land was very poor soil and was very shallow. The taro, sweet potatoes and bananas which throve so luxuriously in that region, were brought up to the city in boats.

The roads were merely horse-trails, and, except one, barely wide enough for running gear. He did not believe that lands which produced so heavy a crop of weeds was poor soil, and judged that it was the system of ownership which prevented them from being cultivated. If he had seen the land at another season when all would be burnt up for lack of water, he might not have come to the same conclusion. The verdant appearance was caused by the dense growth of the indigofera anil plant which had been brought from India with the expectation of cultivating and making indigo. The discovery of the art of making indigo from chemicals had destroyed that hope. He tested the soil and found in many places it was but 12 to I8 inches in depth, covering a strata of coral. Evidently it had been upheaved from the sea and was slowly being covered with alluvion.

They galloped across the plains to Waikiki and watched the natives disporting in the sea. To sit under a hau tree and watch the king and his people riding the surf on boards or in canoes was one of the treats. Surely, of all aquatic sports, this must be the one which afforded the greatest amusement. The dexterity with which they handled their surf-boards, and fearlessness with which they rode waves that threatened certain destruction, was a most fascinating sight to a stranger.

Either the novelty of tropical life or the beauty of all the surroundings, had a charm for "Kansas" and his wife which made them feel that they would strive to make a home on the islands.

The stores where whaling captains obtained their supplies were naturally resorts for these hardy men, and here they delighted to congregate and hear and tell stories of their experiences in the Arctic. It is said that here they have killed more and greater whales than ever were taken, and that the described perils were as vividly depicted as an appreciative audience could wish. To visit from ship to ship was called "gamming," and in calm weather, when no whales were in sight, it was a very common 
occurrence for "the old man" to call away a boat and pull to one of the vessels in the neighborhood for the sake of passing an hour or two in exchanging gossip or to test the neighbor's cuisine. A lot of these captains deligkted to renew their acquaintance in Honolulu, and would sit around by the hour "swapping yarns." The chairs they occupied bore the marks of the knives of the "old skippers" who, unconsciously, in their interest in the recitals, whittled away at the arms or wooden seats. One storekeeper, to protect his furniture, drove tacks in every possible spot, but the next season the shippers industricusly proceeded to dig out the tacks with their valuable pocket knives.

Absentmindedness appeared to be a feature with some of these whaler men. A story is told of one of them who came in coatless, and, having purchased a coat and paid for it, he joined the circle of yarn spinners. Presently he threw off the garment in his excitement of telling a good one. Then he remembered that he came in to buy a coat, and proceeded to fit himself out again. In the thrilling excitement of listening to some startling story, the coat was discarded and he became wrapped up in the narrative. Again he remembered the object of his visit to the store, and he purchased another coat. This was repeated three times during the evening. When closing time came he was handed back the amount he had over-paid. It went to show that sailors and their money are soon parted. Some of them did not, however, leave their business shrewdness on the other side of Cape Horn, where they were said to have left their consciences, and instances are told of storekeepers being induced to put in a bill for fifty sacks of potatoes, against the ship, whereas in fact a gold watch was the merchandise which was delivered.

A glimpse into "Liberty Hall" or "the National" saloons would show how the sailor made his hard earned money fly, and give the reader somewhat of an idea of the effect of rum and white man's influence on the native race. The latter was a twostoried structure with a large saloon on the ground floor, while the second story had two bars in constant occupation during the whale season. Music and dancing enticed the sailors, and numerous native women sat around ready to be partners, either for round or square dances. The latter were most in vogue, as more of the awkward sailors could take part in them than in waltzes or polkas. The caller controlled the dance, and at the end of the fifth figure would call out, "March your partner to the bar," and 
men and women would find themselves lined up to the bar as many as a hundred at a time. Drinks were twenty-five cents each, and when Jack threw down his dollar or a twenty or even a fifty dollar "slug" in payment for his and partner's gin, there would be no change back.

Some told "Kansas" at the Home that they repented, when at sea, of having squandered their hard-earned money, even saying that with comrades in the fo'c's'le they had gone down on their knees and solemnly vowed to God never to touch liquor again, and to save their money for their families at home who were dependent on them. They were so improvident as to even part with their spare clothing, and go to sea without a sufficiency to shield themselves from the miseries of the Arctic cold. Here they would be compelled to apply to the "slop chest," and were again robbed, as the "shoddy" dealt out to them was not worth onefourth the amount charged up for it against their share of the season's catch. 


\section{CHAPTER VII}

HONOLULU AND THE CHURCHES OF THE OLD DAYS-OUR HERO

AGAIN AT SEA, BUT ALONE.

$\mathrm{T}^{\mathrm{H}}$

HEY visited the native churches, as well as the foreign, and remarked that the populace was at least a church-going one. The large native churches were filled to repletion, and they felt repaid by their observations of the congregations. The dress of both men and women was unique, to say the least. Some of the women were dressed in silks, their hats were of the latest style and their colored kid gloves were quite conspicuous. Others were dressed in gaudy colored calicoes, and wore their native hats with wreaths of ferns or flowers. The men appeared to love to display silk hats, broadcloth clothes, and all felt that it was necessary to wear shoes that could squeak, probably to show their newness. However, whatever their peculiarities of dress were, it was apparent that they were devout worshippers, as was attested by the volume of sound when a hymn was given out. Evidently the natives are natural musicians, as the singing was excellent, all parts in the melodies being well sustained. The language seems to be well adapted to song, as much so as the Italian. The preacher, a white man, was very much in earnest, and the congregation appeared to be much interested.

Our travelers could not understand any part of the service, except the tunes, which were exceedingly familiar, such as "From Greenland's Icy Mountains," "Rock of Ages," etc., to which the missionaries had adapted Hawaiian words. A matter which caught their attention was the continual wheezing and coughing all over the vast congregation, and which must have been more or less distracting to the worshippers. Evidently it was the sign of the pulmonary diseases which have decimated the population of the islands, the change from nudity to wearing clothes weakening the cuticle and making the party susceptible to colds and influenza, formerly so freely repelled by a skin inured to sun and rain. 
There were two foreign churches in the city, one a very large one on Fort street, where the most of the fashionable people attended. The pastor in charge was a very eloquent speaker, and was worthy of the large salary it was said he received. The choir was well trained and was not, as in the East, composed of paid singers. Of two of the sopranos one has since made a national reputation as an opera singer.

Our travelers felt more at home in a little church in the rear of the Sailors' Home, called the Seaman's Bethel. The earnest old preacher seemed like a father to his congregation, and was interested in the personal welfare of each member. He often talked with "Kansas" and his wife, and gave them great encour. agement of ultimate success on the islands. In both churches, however, they were taken by the hand by members and made welcome to the city, and asked to call at the different homes.

They needed more than the "glad hand" just then, and it was all depending on his exertions. For his wife's sake he was extremely anxious to live in Honolulu, and to that end sought employment of any nature. Had he a trade or profession he could have done very well, as wages to mechanics were good and employment was easy to be obtained. As an ordinary laborer he could not earn sufficient to keep them.

Much as they admired the churches, Sunday schools and society of the city, and strong as was their desire to make a home in Honolulu, all his attempts to do so met with no success, and they determined that he should visit some of the other islands.

This was their first separation, and they felt very sad over it, and determined it should be but a short one. "Man proposes and God disposes," is an old saying, and in this instance was a true one. He decided to go first to Lahaina, on Maui, and after seeing that island go to Hawaii. Traveling on inter-island vessels is quite expensive, and he asked the captain of a little schooner if he might take a deck passage. The captain said that "white men did not travel that way, but if he was hard up he would give him a passage." He denied being so poor as to be unable to pay his passage and was finally permitted to pay two dollars for a "deck passage" to Lahaina, the captain telling him that he would have to provide his own food and blankets, and that they frequently made the trip in a night, but were sometimes two or three days. Taking his roll of blankets and a package of lunch, he bade his wife and little ones a sad farewell. 
Again he was at sea, but this time on a little bobbing schooner, whose action was so different from that of the noble bark on which they had arrived that he soon succumbed to the mal de mer. Lying on deck with the spray dashing over him, and the wind blowing down onto him from the foresail, surrounded by kanakas, wahines and sea-sick Chinamen, and feeling so wretched, he thought he had reached the lowest round of the ladder. Now and then the schooner would ship a sea, often caused by the wheelman to make the deck passengers squeal; and the combination of pigs, sour smelling poi, calabashes, traveling tins, wet children crying, and sick Chinamen was almost more than human nature could bear. Then when the breeze died out the schooner would roll in the trough of the sea, and the sails would slat about, exposing the passengers to the blazing tropical sun.

Our hero paid very little attention to the view of Molokai or Lanai as the schooner either drifted up the channel or wallowed in the trough of the sea, at times in close proximity to either of these islands. Why a man should go to sea at all, when the United States was still "large enough to give us all a farm," he could not comprehend; and he there decided that he would go back to that fair land as soon as Providence would let him.

The resolutions of a sea-sick man are probably based on the action of the changing positions of the molecules which compose the brain, and are as permanent as the beautiful pictures seen in the ordinary kaleidoscope. Oh, the misery of those two nights up the channel to Lahaina! it burned an impression on his soul never to be effaced. Afterwards he felt grateful that he had been so horribly sick, as his sense of wretchedness was thereby blunted. On the second morning the schooner came to her anchorage at Lahaina, and innumerable clamorous boat boys swarmed her decks, vieing with each other for the privilege of carrying the passengers ashore. 


\section{CHAPTER VIII}

LAHAINA, THE FORMER CAPITAL OF THE KINGDOM-MORE DISCOURAGEMENTS FOR THE MAN FROM KANSAS.

Fros

ROM the anchorage, which is in the roadstead, Lahaina appeared to be embowered in trees, amongst which the breadfruit, cocoanut, kukui and mango maintained the supremacy. Situated at the base of a serrated range of mountains, which were clothed in verdure from the peaks to the sea, it presented the most charming aspect. Many grass huts and a few frame houses lined the beach for a distance of more than four miles, from which it appeared that the inhabitants preferred to live near the shore. On going ashore, however, our hero was surprised to find that the umbrageous foliage concealed the greater part of the town. Streets there were along which adobé buildings, in every stage of decay or dilapidation, ranged themselves.

The first impression the visitor gained was that when a building fell there it was a public improvement. Lahaina had been the capital, and in its day hoasted of the "halepitula," or palace of the king. Evidently, the foreigner had brought there, in earliest days, the art of building houses from adobé, as practiced by the Spaniards in California. These buildings, when kept in repair and the scoving or surface of plaster maintained, present a handsome appearance, but when the thatched roof is allowed to fall off or get out of repair, are very quickly destroyed by the fierce tropical rains.

The coming of the schooner had apparently brought out all the inhabitants of the town and the surrounding country, and our hero was surprised to note the great number of horses and riders dressed in the gayest of colors. He afterwards learned that every man, woman and child owned a horse, pasturing it on any one's land. The natives appeared very friendly, none failing to wish him a hearty "aloha." He found lodgings in a house surrounded with canefields, and after getting a bath and cliange of clothing proceeded to find a restaurant. His first impressions of Lahaina were extremely pleasant, and he hoped to be able to find 
employment there and to get his beloved family again with him, never to part again. Chinese restaurants were numerous, but he found an old Dutch baker who kept a coffee shop, and who had the reputation of making the best bread on the islands. Perhaps he did not do justice to that first meal? The baker thought he was hungry.

On the way up to the sugar mill to seek employment, he did not fail to notice the thriftiness of the cane on either side of the road, and the innumerable stalks which sprang from one hill. It was all under irrigation and grew in trenches where the water was permitted to settle away. Arrived at the mill, he met one of the owners, who talked freely with him of the news of the mainland and of the war and the prospects. After asserting his capabilities as a farmer, he made inquiry as to the possibilities of getting employment. He was promptly answered that they had no work for him, firstly because he did not understand the work, nor the language, and could not therefore act as a luna or overseer, and they would not let a white man work in the fields as a common laborer. Neither could they place him as a teamster or as a laborer in the sugar house. They had natives for teamsters, and Chinamen for dryers and packers, and the only white men on the place were the overseers and mechanics. He told the planter that he was a practical farmer, and could do any part of the agricultural work on the plantation. That he was extremely anxious to get work, as he had a wife and two children in Honolulu to support, and that he would be content with a very small salary until such times as his services were appreciated. The planter informed him that there were no accommodations on the place for a white woman, and they could not employ him.

Crestfallen, he walked away down towards the beach, where he chatted with an American storekeeper. On inquiry as to the consumption of vegetables and from whence they came, he was assured that they did not use much in that line, and that beef and Lanai mutton and taro were the mainstay of Lahaina. Taro grew prolifically in the concealed valleys back of the town, and potatoes came from Kula on the other side of the island.

He seemed to be balked at every turn. He remarked that he saw overseers riding round herding Chinese and natives, and he reckoned he could do that kind of work, or handle the plow.

"Ah, my dear sir," said the storekeeper, "you cannot talk the language, and, moreover, there is not a plow on the plantation." 
Was it possible this great crop of cane was planted by hand labor? Yes, the lands which aggregated this great plantation were all trenched by shovel and mattock. The expense was enormous, but he was informed that one planting was sufficient from which to cut cane for five years, and there was some that had not been replanted in sixteen years. The second and succeeding crops were called rattoons, which, if well cared for and frequently irrigated, produced almost as much as that from the first planting.

Our hero reckoned he would have the proper kind of plow at work if he was the owner. He suggested that he could learn the language and cane culture.

"No doubt of that," said the merchant, "but you will find that planters are not breaking in white men."

Poor white men were looked at suspiciously, unless they were mechanics. There certainly seemed no show for him. He wandered around the plantation observing the manner in which the cane was planted and studying the plant itself. Also he ascended towards Lahainaluna, the college where native graduates from the common schools were finished off. He noted the source of the streams which irrigated the fields, and saw that Lahaina was most aptly situated for an immense rich plantation. On calling at the college he was pleasantly entertained by the principal, and shown through the rooms, and the nature of the studies of the young men. The teaching was in native, and the scholars appeared very intelligent. They did their own planting of taro and sweet potatoes, and their friends furnished them some fish and meats, and altogether the tuition and living cost very little. Many of the graduates obtained employment as surveyors, and some went into law or the pulpit, the majority, however, drifting back to their ordinary mode of life.

Lahaina appeared to have every advantage for sugar culture, not only from its rich soil, abundance of water and proximity to the landing, but from the natural lay of the land, the cane getting the benefit of the sun until the last minute of the day. The heat at midday was something remarkable, but the mornings and evenings were delightful. In the evening he met an old missionary, one of the class he had read so much of in his earlier days. He was invited to call and met the missionary's wife and daughter. They chatted familiarly with him, heard of his wife and little ones with sympathetic ears, and could not realize the barrier which stood between him and an opportunity to earn a liveli- 
hood. The house was one of those old adobé or stone buildings, carefully whitewashed, and having green blinds. Standing back from the street it had the appearance of comfort and home.

In after years, in riding to Lahaina on jury duty or court business, it seemed to loom up as a place where true rest from the heat of the road or business cares was certain. They showed him many curios from the northern seas, presented by their whaling friends, and also many rare shells and curios from the south, which had been sent by brother missionaries. They admitted that he was the stamp of a man the country was in need of, and urged him to keep up his courage and he would get an opportunity to show his worth. The old missionary remarked "That Hawaii was a country where a man found his level sooner than in any other."

How we do love sympathy? It appeared that the few words of sympathy extended to him by these old people had done him more good than anything that had happened since his arrival at Honolulu. They invited him to breakfast, but he declined on the ground that he wished to make an early start for the other side of the island. They said their boys were engaged as overseers on some of the plantations over there, but knew they could be of no assistance, as they were not sure of their own tenure of office, in that it had been decided to reduce the number of employees. A kind farewell, and an urgent invitation to make their house his home whenever he might come to Lahaina again, and he was gone.

At daylight he started with his roll of blankets on his back on the way to Wailuku. As he tramped the roads at that early hour he noticed the laxity of discipline amongst the laborers and the indifferent manner in which the cane was cared for.

How his fingers itched to get a chance at improvements? He was a true farmer, and knew that one hour's work at dawn was worth two at noon. He saw where he considered mistakes were made in laying out rows of cane, that they might obtain the best results from irrigation as well as full play for the circulation of the regular winds. He had an idea that, next to water, air had most to do with the cultivation of sugar. He enquired continually as to the best season for planting, stripping, cutting, etc., etc., and also noticed a difference in canes as to color of stalk and size of leaf. 
Men did not appear to know much about sugar, or perhaps were not as observing as they should be. He recognized that the industry was in its infancy. His time was not all lost. He saw the abuse of the animals on the plantation; evidently they would not live out half the natural work life. He saw the waste of time by the employees, as well as of the animals. Carts with a wheelbarrow load, and carts overloaded, were being driven helter skelter to the mill. He saw men and women idling away their time in the fields, and saw cane growing from roots so old that it evidently had not produced its maximum for the past four years.

And yet the owners got rich. What would the result be if a little brains and push were added?

How delightful the early morning hours are on the islands! The road along which he walked was a path through the Garden of Eden. The hedges on both sides of the road were covered with vines of the wild nasturtium and convolvulus, and innumerable hibiscus and papaia trees shed the fragrance of their blossoms on the morning air. Trees loaded with mangoes, cocoanuts, papaias and castor and croton oil nuts or beans, together with the mass of mimosa and mesquite beans, proclaimed that nature was doing her best to make "life in the tropics" easy for man. The sky was full of light from the rising sun, which is invisible here until quite late on account of the height and proximity of the mountain. The eternal lap-lap of the wavelets on the beach, together with the innumerable sounds of awakening animal life, united to produce a charming picture of an earthly heaven. As he strolled along the Lahaina beach and out through Olowalu and Ukumehame he remarked that some day there would be a large plantation established there. The man from Kansas, with his observing eye and enquiring mind and Eastern vim, would make his mark yet!

As he reached the top of the mountain at Manawainui and caught a view of the Wailuku kula or plain, and got his lungs filled with the invigorating trade winds, he felt glad that he had failed in Lahaina. Here was scope for the imagination. Here were thousands of acres of unoccupied land covered with a magnificent robe of emerald. Could it be that men had failed to obtain possession of this immense tract, or was there some obstacle in the way? Here was room for an immense plantation, probably 20,000 acres. Sugar yielded two and one-half tons to the acre, and sold at $\$ 240$ per ton, while the cost of raising did not 
exceed \$roo. His Yankee brain was at work, and while cogitating matters the ground passed behind him in such strides that he had reached the Waikapu stream before he was aware of it. Slaking his thirst and bathing his head and face, he felt refreshed, and pushed on to Wailuku. 


\section{CHAPTER IX}

IAO, THE YOSEMITE OF THE ISLANDS-DERIVATION OF THE HAWAIIAN WORD FOR LAW-WAILUKU AND ITS DEFINITION.

$\mathrm{W}^{\prime}$ AILUKU, the name of a little village at the entrance of Iao Valley, is also the name of a large tract of country extending across the plain, from one range of mountains to the other, on East Maui. This valley, Iao, has frequently been called the Yosemite of the islands. It is evidently a huge crater, which has been extinct for ages, whose precipitous sides are clothed with perennial ferns and evergreens. It is an admirable basin for catching water, which from ancient times had been guided in ditches out onto either side of the valley to supply the myriad of taro patches of the ancient inhabitants.

Far up in the valley can still be found signs of the cultivation of the soil by a people whose great numbers had compelled them to live in a part that, on account of the absence of sunlight, was so uninviting. From this valley, however, many of the Hawaiian necessaries of life were obtained. Here grew the ti leaf (dracena terminalis, or cordyline), which serves as a wrapper for food, for plates, for a vehicle for cooking, for the scant clothing of the ancients, for thatching temporary huts, for medicine, and a thousand other uses the Hawaiian puts it to. It is greedily eaten, also, by the herbiferous animals, and its root, which grows very large, is much sought as a very sweet and nutritious food. Unfortunately, like many other vegetables, it contains much alcohol, and was used by the ancients for making a beer. The white man showed them how to make a spirit from it, which was called okole-hao, on account of a musket barrel being used to convey and condense the steam from the boiling expressed and fermented juice. To this introduced art may be ascribed much of the fatalities of the Hawaiian.

In this valley grew, also, the kukui or candle nut, used by the natives for making their torches. The raw nut is very laxative, and is used also as an emetic. The husk of the nut makes an indelible dye, and is an astringent used in medicine. When 
roasted it forms an exiellent condiment, and is always used in feasts.

On the sides of the ravines which open into the valley grew the olona (touchardia latifolia), so useful in making fish lines and nets. Also the wauke ( $B$. payyrifera), from the fibre of which their cloth and quilts were made. The valley was the source from which they obtained many of the herbs whose medicinal qualities were well known to the kahunas, or doctors.

Above all, however, the valley as a catch-basin for water was most appreciated, as this district supplied foodstuffs for a large section of the islands. Most of the internecine wars had arisen on account of disputed water rights. Time and again had rules been made for the equable division of the water, only to be broken by some overbearing neighbor. These rules had been committed to memory and passed down from father to son, and were termed "kanawai," meaning pertaining to water, and from thence comes the present Hawaiian word for law.

The rivalry for the life-giving water extended far from the banks of the stream, and many people from a distance were dragged into the wars which took place, either to defend rights or to overpower those who maintained them. Taro from the patches in Wailuku was, after being cooked, pounded and wrapped in bundles in ti leaves, carried great distances, and in times of famine to other islands of the group.

This valley was the scene of one of Kamehameha First's great battles, where, aided by fire arms procured from traders, he was enabled to overcome Kalanikupule, king of Mlaui, and permanently add Maui to his conquests. It is said that the battle raged so furiously, and that the number of slain was so enormous, that the opening of the valley was so filled with the dead as to dam up the stream, and when it burst away the river ran pure blood, the valley being thereafter called "Wailuku," the water of slaughter.

The ancient name of the stream is unknown. Judging by the traces of cultivation, the district on the eastern slope of West Maui must have been densely inhabited. Four fine streams issue from this range called respectively, "Wai-kapu," tabued water, "Wailıku," "Waielıu," muddy water, and "Waihee," retreating water. The district was called "Nawaieha," from these four streams. Today these streams give names to little villages which nestle up against the spurs of the range, the lands adjacent to which have been mostly utilized for cultivating cane. The once 


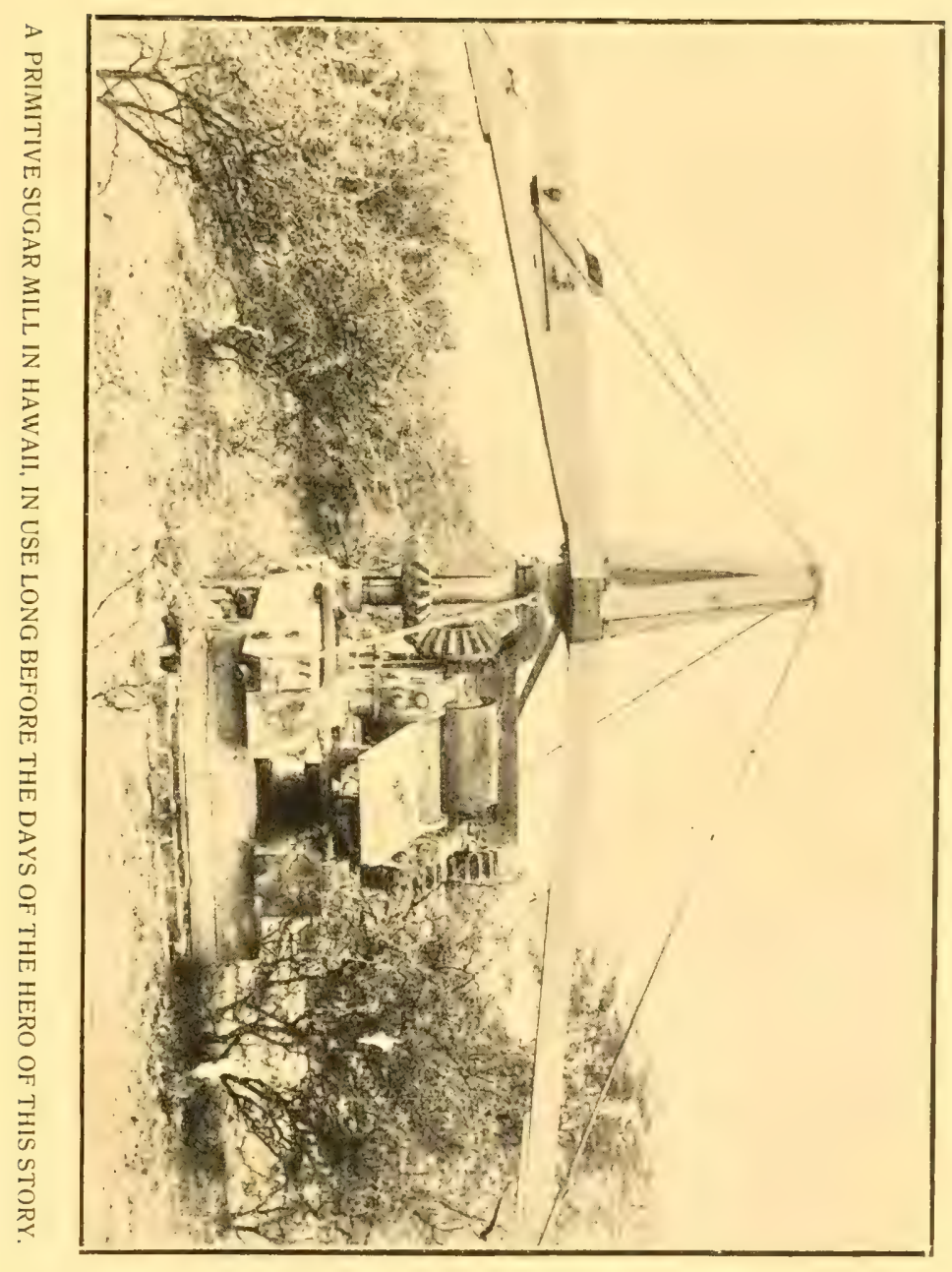



numerous inhabitants have been superseded by Asiatics and whites.

Fine stone churches, each with a handful of members, stand as monuments to the labor of the early missionaries in each village. This also is the history of every district on the islands. Imported cattle have denuded the mountains of verdure as far up as they could climb, and reduced the water supply by destroying the rain and cloud-catching evergreens.

Nature will soon recover, however, if the cause is removed. It is said that in old times great numbers of cocoanut palms grew along the sea coast, below this district, not one of which is seen today. All had been destroyed in the frequent internecine wars, and the sugar planter finds the trunks embedded deep in the alluvion carried down by the furious torrents which take place almost annually. The harbor of the district, Kahului, is a very beautiful one, and yet has not the necessary protection from the sea to make it a safe one at all seasons. The fishing rights of the chiefs of the different lands, bordering on the sea, were most strictly enforced, and the natives being expert fishermen regularly fed the fish to encourage them in coming. From the sea the range of mountains with the extensively cultivated lands in the foreground, makes one of the prettiest pictures of island scenery. 


\section{CHAPTER X}

AT WAILUKU "KANSAS" IS ADVISED TO "KEEP ON TRYING" IN SPITE OF THE DISHEARTENING OUTLOOK.

A RRIVING at Wailuku, and securing good lodgings and get-
ting refreshed, our hero strolled down to the sugar mill. The manager was a very pleasant man, invited him in and showed him the whole working of the establishmentthe grinding, liming to correct acidity, boiling in open train, distributing into coolers for crystallization, and packing in kegs for the market. Here all seemed to go like clockwork. The mill was on a side hill, and half of the cane of the plantation had to be carted across the valley and up the hill. Once up, the whole process was down, down to the very cooper shop where the kegging was done.

"Did it pay to haul; would it not be better to have the mill lower down?" queried our hero.

"Yes," the manager said, "but the mill was here, and we cannot make up our minds to make the change."

This man appreciated the man from Kansas, and invited him to dinner and to spend the evening. $\mathrm{He}$ is a bachelor, and will be glad of company. Then comes the after-dinner chat on the veranda. The Kansas man finds it takes longer to bring cane to maturity in Wailuku than in Lahaina, as they preferred the native red cane which was slower in growth than the small yellow cane used there.

"Would it not pay to try the Lahaina cane?" asked "Kansas."

"No," said the manager, "we are perhaps prejudiced against it; any way we think the cane we have is the best adapted to this section."

The Lahaina cane is richer in saccharine matter, but it is so small.

During the conversation the manager heard the whole story of our hero's adventure to the islands, and realized his trouble.

"You will have an up-hill fight, my friend," said he. "This is not a poor man's country. Of course the poor are the most nu- 
merous, but how are you going to get a start with the weight around your neck which you have in the form of a wife and family? They must live, and you cannot get any pay worth speaking of short of two years hence."

Then the Kansas man told him of the waste and lack of economy, and of intelligent culture he had observed, etc., etc. The manager replied, "What you say is true, and we have not got down to Eastern economy and methods yet; but the profits are so large that we can afford to overlook those little things."

"Some day you will not overlook anything," said "Kansas"; "all will be needed in competition." Then he asked if the manager could give him employment.

"No," said he, "although I believe you are competent and will eventually succeed. I have run over the whole field and do not see where I could place you. There is nothing but the most demeaning work I could set you at, and I would not do that."

"What yould you advise?" said "Kansas."

"Keep on trying. Go to Waihee and see their plant. They may be able to place you, but I understand they have a whole lot of missionary boys there and have orders to cut down their force. Anyhow, I should keep on trying."

It looked very blue for this practical man, that he could not get an opportunity to show his worth. 


\section{CHAPTER XI}

THE MISSIONARIES HAD TROUBLE, TOO-OUR HERO HAS WORK AT LAST, BUT AS "SHIPPED MAN."

T HE next morning our hero started for Waihee, a distance of three or four miles. Walking through the fields, he took note of the careful manner in which the cultivation was done, the plow being used everywhere, and the cane laid out in rows in most systematic manner, so that while getting the full benefit of the irrigation it also was open to trade winds so far as possible. He was overtaken by a man riding a mule, who accosted him in a friendly manner and conversed with him in regard to his impressions of the country and especially of the fields. "Kansas" replied that what he saw came nearer to his idea of a proper method of cultivation than on any other plantation.

"I am glad to hear you say so," said the rider; "I am the manager of Waihee plantation, but one of the missionaries of Lahaina laid out the plowing and planting, and is overseeing the cultivation."

The rider asked him if he was interested in sugar. He replied that he was deeply interested; and then as they went along told him the story of his great desire to learn the business, and of his capabilities in the farming line. The manager said, "You are the kind of man we want, and we would like very much to have you and your family settled with us and form part of the small society at Waihee; but, unfortunately, I am not able to give you employment, as I have orders to cut down my list of employees, and must even part with my brother-in-law."

He invited him into the mill and showed him through the whole works. It was truly the best mill and plantation on the islands. Everything was on a large scale. It had the most land, the most water, the best management, and in many ways was the best property our hero had seen on the islands. He was invited to dinner, and met the manager's nice family, and talked over his own prospects. The manager advised him to persevere and he would assuredly catch on somewhere. 
"The sugar industry is in its infancy," said he, "and not onethird of the land on the islands adapted to its culture is under cultivation. It is bound to be the coming industry and maintenance of the islands, and will take the place of whaling."

As our hero parted with him and his wife and family, all of them wished him god-speed and success, and invited him to come again; and they would be pleased to learn of his locating himself.

Sadly he walked back to Wailuku, in a very depressed state of mind, and could not understand why he should be debarred from working at his beloved vocation. Then he wrote fully to his wife, explaining at length the attempts he had made, and giving a terse description of the beautiful country, depicting the horrors of the sea trip and his disappointment in obtaining work. He spent several days in Wailuku, and tramped the valley and looked over the surrounding country. He became acquainted with two old missionaries, and from them learned very much of the manners and customs and history of the Hawaiians, as well of the history of the mission and their early trials. One of these came out as a teacher and devoted his life to inculcating the native youth, especially girls, in the rudiments of education, being aided by his amiable wife in teaching the details of home keeping. as sewing, washing, cooking, and all the little arts the knowledge whereof has made our mothers the true helpmeets they have bcen to their husbands. He had also introduced cotton and endeavored to cultivate it and manufacture cloth.

The other missionary was a preacher, and conducted services in the stone church in the village, as well as maintaining a theological school from which native missionaries were graduated, several of whom were sent on missions to the South Seas, while others occupied pulpits in the islands.

Judging from their erudition and kindly natures, it is certain that if these men had not felt called to give their lives to leading the heathen of the Sandwich Islands to the light, they would have risen to eminence amongst their fellowmen of the Fastern States. In their homes he was made welcome, and when they became accluainted with his abilities and character he was encouraged by them to persevere in his endeavors to learn sugar culture, and the requisite knowledge of the vernacular of the country. Towards the latter he was given very valuable assistance and directions as to how to learn the language the quickest.

Having more than a week to wait for an answer to his letter, 
he took every advantage of the time, in company with the aged preacher, to study the language; and during that time he learned very much of the hardships the early missionaries passed through. The preacher had been one of the fourth reinforcement of the Mission to the Hawaiian Islands, making with his wife nineteen in all, on board a vessel which was six months in coming around Cape Horn. After a passage which must have been one of misery from the exceedingly cramped quarters on board, but which was never referred to by him other than to speak of the beauties of such lands as they saw, and of the extreme kindness of the captain and officers of the vessel, ther landed at Honolulu, and were almost immediately sent off to the Marquesas Islands as prime missionaries.

His wife described the horror of life there, which fortunately for them was limited to but eight months, as the English mission had undertaken that field. The people were of the lowest type of humanity, nude, rude, uncouth, cannibals, thieves, and were terrible. On their return to Hawaii they were stationed on Kauai for nine years, where he learned the language thoroughly and lahored assiduously amongst the people with great success. On his health failing there he was sent to take charge of Lahainaluna academy until I849, when he was given a year's rest, which he occupied in surveying on the mountainous region of Maui and aiding the natives in procuring titles to their allodial estates.

In 1856 he accepted a call to the church at Wailuku, where our hero met him. He had supervision of several churches in the district, and journeyed from one to the other on an ambulating old horse, on what was called "the missionary trot." He was beloved by all who met him, and the vilest white man or the lowest native had a good word to say of him. His salary, or stipend, was exceedingly limited; but they were enabled to rear a family of nine children, all of whom received educations above the average. The old gentleman was of Kentucky stock, and fearless in denouncing any crookedness on the part of the king or those in authority, and yet withal so liberal in his views that no one could take offense.

At the golden wedding of the old couple, which is spoken of in a later chapter, his oldest son, in an address to the parents, said: "By example much more than by precept, you have taught us to live for something higher than what the world counts success, and to seek the favor of God more than the praise of men. 
We thank you that you have taught us to be rather than to seem; to abhor all that is false and all that is sordid or base; and to cultivate charity, forbearance, humility, and other old-fashioned virtues,

\author{
"And thus to bear without abuse \\ The grand old name of gentleman, \\ Defamed by every charlatan \\ And soiled by all ignoble use."
}

Truly a character whose name should be enrolled on the scroll of fame, and one whom all men should hold up before them as an ideal to which they should aspire to shape their lives.

The following week "Kansas" received an answer from his wife, which electrified him. Quick-witted woman; loving helpmate; she writes, "We have enough to live on for two years, even if you should not do a stroke of work during that time. Get a job on a plantation on any terms, and learn the language and the business. I can earn a living, if necessity compels it, where I am." She always appreciated her hushand and had taken him "for better or for worse," but so far had found him "for better."

Now he determined the course he should pursue, and we will see in the following chapters whether she was wise or otherwise. A woman's instinct is often better than a man's deeply thought out scheme.

The following morning our hero waited on the Wailuku manager, and tendered him his services, in any capacity, and at any figure he should offer. The latter flatly refused to employ him, saying he could not endure seeing a white man of his standing at menial work, suitable only for coolies, and he had no other to give him.

He was loth to leave Wailuku, where he could have the companionship and instruction of the preacher in whose company he delighted, and on whose every expression he hung as we have seen students in our colleges following the lecture of a great professor. He called on the preacher and told him of his resolution, and was iuvited to call at the parsonage whenever he might come to Wailuku.

Bidding his new friend and his charming wife farewell, our hero tore hinself away. With his roll of blankets on his back "Kansas" trudged across the Wailuku sand dunes and plains and ascended toward Makawao. Makawao is the name of a large 
part of the western slope of East Maui, and has the reputation of being one of the dreariest parts of the islands, being windswept by a zephyr which from old times was called " $\mathrm{Ka}$ ua ukiukiu o Makawao," (the whistling rain of Makawao).

Notwithstanding its bleakness, Makawao was noted for the richness of its soil, and its concomitant good crops, as well as the healthfulness of its inhabitants. It was a weary, hot walk, but our hero now had much to occupy his thoughts, and as he toiled through the red clust and heat he dwelt with delight on the instructive conversations he had enjoyed with the preacher.

Resolutions and plans for the future were formulated, the success of which would depend upon circumstances. Towards noon he came to a plantation and sought out the owner, amongst the intricacies of the mill, to whom he applied for work of any kind. Many of his appearance had tramped the road before, and the planter had good cause to look on them suspiciously. After scanning his appearance and questioning him somewhat as to his wish to do land-work, for all loose white men were presumed to be runaway sailors, he was told that he could have work, "but," said the planter, "no one works here who is not shipped, and if you are willing to ship your job is ready for you."

$\mathrm{H}_{\mathrm{e}}$ wotild not take him unless he signed a contract to work a definite time at so much per month, and to do any kind of work he was set at, either in the day or night. "Kansas" now found that he had obtained what he had so long sought, viz: the opportunity to learn the business of sugar planting, and all that implied, and determined to accept the terms, no matter what they were. The terms offered were "eight dollars per month and found, ten hours' work per diem, to work by day or night as directed, twenty-four dollars in advance, and to engage for one year."

The contract was signed in duplicate and acknowledged, and "Kansas" was bound to work or be imprisoned.

He was shown a room, about Io by 12 , in a cottage having two such rooms and a veranda in common. A bed, table, chair and wash-stand completed the furniture. The cottage faced towards West Maui, and from the veranda one of the most glorious pictures of ever-changing scenery presented itself. $\mathrm{He}$ soon freed himself from the superfluous real estate collected on the long tramp, and after his ablution and a little rest felt that he was going to like his new liome. Naturally it appeared barren and cheerless, but he knew he could soon surround himself 
with the few necessary comforts, and felt grateful for his success,

At dinner time he went in with the mechanics, and had a good, hearty meal, and was told that he was not expected to go to work until the morning, He passed the afternoon in walking about the premises, and taking note of the mill and surroundings. The planter told his wife that "he had shipped another white man, and that he would prove either a jewvel or a devil." She remarked that his "runaway sailors had not proven to be of much value as farm hands."

The next morning "Kansas" was set at piling firewood, and he put in a good day's work. The climate was cool and bracing, and he felt that he could do as much work per diem there as in California or Kansas. The wood piling initiation lasted but a few days, when he was set to work with a Portuguese mason building stone walls, of which there were miles on this plantation. Stone walls had a two-fold purpose, viz: to clear the land of rosk, which protruded in many places, or to make partitions between fields wherein cattle were kept. The Portuguese was a good workman, and the novice took his first lessons in masonry willingly. The most of the walls were built by building suitable rocks as a base and placing the upper stones on in such regular manner that they would stand for all time. Often near the gates mortar was used in building, to give the work a clean cut appearance, so our hero learned stone-wall building, with and without mortar, and this lesson was not lost on him.

After three weeks of this out-door work he was set to washing the floors of the sugar-house. There was no other road, he had to do as others did, and bravely and good naturedly, in his bare feet, he plied the bucket and swab. It was a wretched mill, poorly planned, and its machinery was in keeping with it. Novice as he was, he could not help noticing that the bagasse, as the trash or pulp which came through the rollers was called, was not as dry as it should be, and a large percentage of the cane juice was thus lost. This bagasse was thrown out and spread on the ground surrounding the mill, and there by hand-turning dried in the sun for use as fuel, in addition to the large quantities of firewood hauled in from the forests. It was the endeavor to produce as much No. I sugar as possible, and this caused the molasses tank to fill rapidly. Molasses was of very little value on account of the high freight and heary duty at San Francisco. 
The darkey stigar-boiler was a very careful man, and watched the cane as it came to the mill, and tried to separate that which was rat-eaten or borer-punctured, as those stalks were sour and affected the whole mass with which they blended. Still they had to go through, and it required a much larger weight of lime to be used to correct the acidity; and also, as a consequence, a correspondingly less proportion of No. I sugar could be obtained. He strained all the juice which came through the rollers, and anything which went through his screen rose to the surface of the first clarifier, where heat was applied. He seemed to be quite secretive in regard to the quantity of lime to be applied, and how he arrived at the proper weight to be used. He made good sugar, if it was a poor mill, and that satisfied his employer. $\mathrm{He}$ watched the men working at the train, as the row of open kettles was called, and kept them continually sweeping the surface with long paddles. He also pursued the firemen to keep up a regular flame, a very difficult matter where they had to feed the furnace continually with dried bagasse.

Paddling, bailing, and skimming seemed very hot work, as the poorly-ventilated mill appeared to be filled with steam from the boiling juice. The mill-men were all natives, who seemed willing to turn their hands to anything. They chaffed the man from Kansas and told him he could not stand their work. They wore only pants made of denims, and the perspiration poured down their breasts and backs. He "reckoned he could do anything that a kanaka could do," and this remark being quoted to his employer, he found himself set at "sugar boiling," as the boys called it in derision. The sugar-boiler was the best paid man on the plantation, but skimmers of boiling pots received but seven or eight dollars per month. After a few days he found it very agreeable work and far from being unhealthy. How his wife cried as slie read his weekly letter wherein he graphically described his life on the plantation. He made no complaints of the hardships he endured, on the contrary, described every thing in a humorous vein; but she could read between the lines, and in imagination followed him as he stood in the cloud of steam skimming the train, or, barefooted, washing the gummy floors.

He had described the process of drying sugar, and she could see him bare-footed and bare-armed tramping in the coolers where the boiled juice had crystallized, digging it up and filling it into tubs, which by the help of a native were carried to a cen- 
trifugal and dumped in. This machine was about the size of a large wash-tul), and had wire-gauze sides and turned on a spindle at the rate of $\mathrm{I} 600$ to 2000 revolutions per minute.

The centrifugals were enclosed in an iron frame to prevent accident in event of explosion. Still accidents happened sometimes, from the carelessness of the men or from the slipperiness of the floors, caused by the dripping of the syrup. Should a man become over-balanced and fall into the centrifugal while it was in motion, it would be almost certain death. Such an accident happened to a poor kanaka who worked in company with our hero,

Our man felt that death liad come very near to him that time, and imagined the consequences to his wife and little ones should he have been the victim of such a catastrophe. When his wife read of the accident she wrote him that he was her all, and although she had the greatest cunfidence in him and his carefulness, she urged him for her sake to be careful. The local papers made a great ado about the accident, one editor insinuating that the planter was not wholly guiltless of manslaughter in allowing the floors to become so sloppy. It had a good effect, in that thereafter the floors were kept in somewhat better condition. The works were closed for the day and the floors and mill cleaned up. 


\section{CHAPTER XII}

SOCIABILITY ON THE PLANTATION AND AT CHURCH-“AND HE PROVES TO BE A JEWEL"- "KANSAS" MAKING HEADWAY.

TH

HE planter's wife, a most estimable lady, was accustomed to visiting the makahiki houses, as the quarters was called, to look after the comfort of the men and women. During our hero's first week she called on him, and told him that services were held in the church in Makawao, and he was welcome to the use of a horse to go there if he chose. He took her at her word, and the following Sunday morning found him on the road to church. It was an exceedingly interesting service to him, although the sermon was more or less prosaic. Although all were strangers to him, they had the same old hymns to which he had been accustomed in his New England home, and he gladly joined in the praise service. He had a rich baritone voice; and the lady who played the little reed organ seemed to throw her whole soul into it.

The small congregation appeared to pay the strictest attention to the sermon, and was very devout. After the service there secmed to he a great deal of handshaking and pleasant chit-chat amongst the neighbors, but our hero was unnoticed. Not entirely umnoticed, however, as several asked who he was; one planter, who was a great lover of music, remarked that he had a very fine voice. His employer's wife told that "it was another deserting whaler whom her husband had shipped."

When "Kansas" was untying his horse the preacher's daughter came up and offered her hand, saying, "You appear to be a stranger in our community, but we are very glad to see you." $\mathrm{He}$ offered to assist her to her horse, and she accepted the courtesy. He opened the gate for her, and as she passed out touched his hat to her, but she wheeled her horse about and remarked, "We live a mile or so above here, and have an abundance of figs, if you would like some." He mounted his horse and was soon beside her. Some of the ladies remarked, "That is just like Mary, 
she speaks to every one." However, he had a pleasant chat with an intelligent lady: which he never forgot. He told her that he was a contracted laborer on plantation. She said, "We are glad that you have come to live in our neighborhood," and hoped he would come regularly to church. He promised her that he would do so, as it made a pleasant break in the week, remarking that he considered the keeping of the Sabbath Day holy (or wholly) was one of the great reasens why the Anglo-Saxon race had taken such a lead in the world's civilization.

Arrived at the parsonage he was told that he was welcome to all the figs he wished-and they were truly delicious. Those large purple figs, how he revelled in them: they certainly are the most delicious of any on the islandls. He was invited in to lunch, and met the aged preacher and his aniable wife, and spent an hour in conversation that to him was most instructive. The old gentleman had lived long on the islands, and he and his son and danghter had felt it their duty to go home and take part in the Sanitary Commission in the war. In his old age the parson had thought it alvisable to marry again, and in the East harl found a suitable mate to share his declining years. As fate would have it, a second family, of two, sprumg up to add to their pleasures. However, we are not giving the listory of cach of the delightful
people he met.

On his way down the long, tedious road he communed with himself, recailing the kindness of the mission family at Lahaina, and that of the two at Wailuku, and of the close friendship which had sprung up between himself and the preacher at the latter place; all their hearty invitations to him to come again when passing. They had made no class distinction of him in their association. Ile felt that the thought he was harboring, that the rich marle an incisive distinction hetween themselves and the poor laboring class, was erroneous. Was not the distinction purely mythical on his part? Was it not engendered from overhearing on the wharves in San Francisco and in ITonolulu such remarks? He feared he himself was the originator of such a fancied distinction. He knew of the extreme hospitability of the planters between themselves, as he harl noted the frequent arrivals and departures of travellers at the plantation, and concluded that they were somewhat right in heing reserved in taking to their firesides people of whose antecedents they knew nothing. 
For his part he would keep on in the even tenor of his way and mind his own business.

That afternoon the planter's wife visited the quarters, and brought some religious papers for his use. She remarked, "I see you are accustomed to going to church; I could tell by your familiarity with the hymns."

"Yes," he answered, "it makes the day pass quicker when one goes to hear a sermon, and besides the incentive to spruce up keeps a man from getting lazy." She hoped he would go regularly, and try to induce the mechanics to come. However, she offered him the use of the library at the house, provided he did not soil the books. Her kindness was so much greater than he expected that he felt that he was misjudging the entire community. He thanked her for the use of the books, and assured her he would be very careful of them. Here indeed was a treat.

What cared he for the men who looked down upon him on account of his poverty, and being a "shipped man," when he could have the company of such men as Tyndall, Lyell, Huxley, Darwin, Hugh Miller, and a host of other scientific writers, as well as of atithors of works of fiction too numerous to mention? It put new life into him to look forward to the pleasant nights he would have in such company. The work was hard and the hours long, but neither as hard or long as he had been accustomed to in Kansas and California.

The planter had a very valuable library, selected with good judgment by some one who knew what was necessary to keep in the country. Of works on the steam engine, chemistry, botany, political economy, history, geography, etc., etc., there was a plethora, besides a number of periodicals. This privilege of using the library was a gift which for once was appreciated to its fullest extent. It was like a shower of rain on a thirsty soil. Never in his life before could he comprehend so thoroughly what he found in books. Day by day he worked away at the mill, doing all kinds of work, from firing up, cleaning boiler tubes, cleaning the engine, shimming, drying sugar, feeding the mill or turning trash in the mill grounds in company with native men and women.

Sometimes he would be sent with the teams into the woods towards the rainy side of the island, for firewood, during which trips he learned much of the nature of the Hawaiian forests and of that part of the island. He saw the effect of the pasturing of cattle amongst the large trees. They destroyed the dense 
tropical under-growth which preserved the moisture, and in a few years large trees died. It could be but a matter of a few years when the windward slopes of Haleakala would be denuded, and this barrenness would affect the rainfall most injuriously to the balance of the islands. Sometimes the gang of teamsters would be placed under his charge, and he could not but notice with what reluctancy they obeyed his orders. He was of the same contracted class as themselves, even if he was a white man. Still he got the work out of them, and with a little tact succeeded in getting back early in the day with satisfactory loads.

Little by little his employer came to lean on him for service of many kinds, and he was frequently on horse-back in all parts of the estate, either with a gang of men or carrying orders for changes to the different overseers. This gave him a great insight into cane at different stages of growth, and into the extent of the estate. He could see the absolute waste in the attempts to cultivate cane on parts which had proven valueless, and also he could discern the necessity for correctives and fertilizers to certain soils. In so broad an estate there must naturally be a variety of soils. To treat all alike, therefore, would be wasteful and reprehensible. Still this was exactly what was going on.

Fortunate indeed was the planter, that prices of stigar ruled so high and wages were so low. Nature had done so much in supplying a rich soil, brilliant sunlight, and wind, and ample rain, if man only had the requisite knowledge to take advantage of those blessings. "Kansas" noted the errors made or permitted, and also made note of what he would have done if he was the owner. Of course it would be out of place for him to offer suggestions, but at times he did so when opportunity favored it, or when his opinion was asked.

His employer told, at the table, that he had said "that 'Kansas' would either prove to be a jewel or a devil, and he proves to be a jewel!" His wife remarked that "Kansas" was a great reader. Her husband said, "I do not care how much he reads, as long as he does my work well, and I must say he is the only wohite trash I have ever met who does well and quickly everything that is entrusted to his care. I sent him with the teams over into the forest for wood and he was back here in half a day, whereas any luna I ever sent before aiways managed to keep the boys and cattle away until night. He can build a stone wall as good as 
Portuguese Joe. Bob White says he knows as much of the principles of the steam engine as he does, and I guess he is right about that, although Bob is pretty handy when anything is broken down. I have an idea that the fellow could boil sugar. Old John has to go to Lahaina on the jury next week, and I have a notion to give 'Kansas' a show to see what he can do in that line." 


\section{CHAPTER XIII}

SOME INTERESTING DETAILS OF PLANTATION WORK-THE ENTRANCING HALEAKALA TRIP AND WHAT IT REVEALS.

$\mathrm{T}$

HE following week, when John was off to Lahaina, our hero was set at sugar boiling, although under the eye of the planter, who was himself a master hand. He got along famously, in fact he was surprised that there was so little in it. As the juice came in from the rollers he skimmed or rather strained it, for naturally much fungus which grows on all cane, came over as well as detritus of other descriptions. Judging by the taste and color of the juice, he could tell if acid prevailed in injurious percentage. In such case lime was applied, but great care was used in this respect, as the chemical action of the lime on the saccharine matter prevented crystallization to some extent, and also changed the nature of the product.

When heat was applied in the container in which the juice was received it caused all extraneous matter to rise to the surface, from whence it was skimmed, and the heated juice was again strained before going into the first of the train of boiling pots. Here it was boiled and evaporated to a certain consistency, determined by the saccharometer, and finally its proof density was determined by hand-testing. It was then conveyed to large tanks, which were probaliy $\mathrm{r}_{5}$ inches deep, and presented a large surface to the atmosphere, where it was allowed to crystallize, and from whence it was carried to the centrifugals.

Patience, watchfulness, and prompt action to arrest the graining at the proper stage-that was all, excepting the prime necessity of keeping all the kettles scrupulously clean and free from fermentation. For two days the planter fumed and puffed about the mill, which was as much as he could endure, and the third day he was off to the port of Kahului, where his vessels lay at anchor. He said, "Now 'Kansas', be careful and do not burn that sugar, a strike is worth more than your year's wages!" and he departed leaving our hero in charge of the mill and all the men therein. 
There was no sugar burned there, and if the planter had been a little more observing he would have noticed that the output was a little larger for the next three days. He had taken note of old John's watching for rat-eaten or borer-punctured cane, or that which had not reached its proper stage of ripeness, and set such aside to be either destroyed or ground together. He soon learned from the color of the juice, as well as the taste, the requisite weight of lime to use as a corrective to the acidity. By the saccharometer he discerned the difference in the density of the juices from different fields, and formed an opinion of the causes of the difference.

He was too good a farmer not to know that sugar is made in the fields, and not by any chemical concoction in the mill. The essentiality of preserving the crop at the mill and curtailing all waste there was also very apparent. Where proper cultivation was used, and the cane kept clean, that is, stripped regularly of the older leaves within which the borer lays its eggs, and where the puncturing is done by it, the yield of juice was not only greater but its percentage of saccharine matter was much higher.

Our hero reveled in the delights of every part of sugar cultivation-the plowing, manuring, cultivating, stripping, and harvesting the crop. 'The different stages of labor he went through, instead of being laborious, irksome and unpleasant were done by him with a cheerfulness and earnestness and watchfulness which could produce none other than an appreciation by his employer, and which would create a lasting impression on his part.

The bracing climate of Makawao, and his care of his person, combined to ensure him good health, and he grew robust and tough in all his muscles. Frequent long and hard rides made him a good horseman, and every opportunity was taken by him to learn the geography of the island as far into the Koolau country as the district of Hana. Situated at such an elevation as he was, he had a continual view of West Maui and the beautiful villages along that range of mountains, together with their whitewashed mills and churches. It truly was one of the most beautiful landscapes to be found in any part of the world, with its variegated colors, the sea and the land, the light and shade, and the view into the great valleys.

"Kansas" was not always confined to the plantation, and on more than one occasion had been detailed to travel with a party to Ulupalakua, a fine plantation owned by Capt. Makee, situated 
on the other shoulder of the great mountain. This was at an elevation from I 800 to 2500 feet above sea level, and where they were entirely dependent on the rainfall for their crop and for living purposes. The owner was truly one of nature's noblemen, and delighted in entertaining his neighbors or strangers from all parts of the world. He was very broad in his views and liberal to a degree. He was always pleased to have an opportunity to converse with men from whom he might possibly learn something, and was no respecter of men's clothing.

The first time "Kansas" was there the Captain noticed with what assiduity he cared for the horses, apparently being as solicitous for their welfare as for himself. He, although anxious that the stock should have water, saw that they did not get much until they were cool enough from their journey, that it would not injure them. Then he took care that they had plenty of rich cane tops, and fed them himself.

These little matters attracted the Captain's attention, and he took the first opportunity to get into conversation with our hero. Like all the old sea-dogs, he was addicted to an early cup of coffee, and seeking out "Kansas" he invited him to partake of coffee and johnny-cake with him.

"Kansas" had climbed to Prospect Hill, a knoll planted to encalyptus by the owner's directions, and from where a good view of Ulupalakua plantation and the vicinity was to be obtained. He was asked as to his opinion of the site for a plantation, and of the soil. The Captain was surprised to note the wealth of knowledge that this hostler had in regard to agricultural matters in general, and of the notice he had taken of the immediate surroundings.

During the three days the party remained there the Captain, without any apparent neglect of his guests, sought as much as possible of "Kansas's" company. At other times, when he visited there, he was made as welcome as if he was one of the nabobs of the islands: and when Capt. Makee visited Makawao, he asked for "Kansas" and showed him every courtesy, to the astonishment of both his empioyer and the mechanics of the place. We will see in later chapters how this acquaintance ripened into friendship, and to the Captain's financial benefit. "Kansas" was frequently at Wailuku and Waihee, and renewed his acquaintance with those whom he had learned to appreciate in those villages. 
At one time he was sent with a party to Haleakala, the huge mountain, I0,000 feet high, at the base of which his plantation was situated. The party consisted of a U. S. Geological Commissioner, two islanders and the guide, a missionary's son, who lived well up the mountain and was familiar with the intricacies of the numerous trails which crossed and recrossed each other in a thousand directions. They started early in the day and at evening were at the summit.

From this point the view is grand, all the islands of the group being in sight, the overhanging cloud effect entrancing the tourist and chaining him to the spot. The horses were quickly tethered, and a large lot of firewood collected from the scrubby growth of brittle shrubs which covers the surrounding country. After the sunlight had diminished the cold was intense, and the party bivouacked in a cave at a little distance below the summit. Having disposed of supper, the party grouped themselves about the fire at the entrance to the cave, when "volcanoes and their causes" were disctissed.

The Commissioner had traveled over Yucatan, Mexico and the southwestern States and Territories of the Union; had visited and followed the wonderful Colorado river from its source to its mouth in the Gulf of California, and had formed his theories of subterranean forces.

He had visited Kilatiea, Mauna Loa, Hualalai and Mauna Kea on the island of Hawaii, and remarked on the peculiar absence of many of the volcanic products found in other parts of the world. He reasoned on the difference between $a a$ and pahochoc, formations in the flows on Hawaii. Spoke of the rapidity with which these corroded, disintegrated and dissolved, and of their forming soil of the finest character in so short a period.

Our hero was entranced with the conversation, and although it was his duty to "fire up" and care for the trembling horses, he was loth to leave the circle of discerning educated gentlemen long enough to preperly attend to these. The Commissioner noted with what interest he listened to the conversation, and, as the fleas drove sleep from the eyes of the weary party, he continued the conversation on through the night. It was "a feast of reason and flow of soul" which needed no artificial stimulant to sustain.

At dawn they were on top of the mountain watching for the coming of the glorious orb of day. This is one of the grandest sights it is in the power of man to obtain. The face of the earth 
was buried in cloud, excepting the pinnacle upon which the party stood. Presently the bright rays of the rising sun pierced the eastern horizon sufficiently to lighten up the whole upper surface of the downy strata which covered mother earth, and then the brilliant disc seemed to burst from the shroud which enfolded it, and Sol, in all his glory, began his diurnal journey. Rising majestically, he appeared to draw up with him a large part of the downy strata he had cleft, which presently appeared to fall back to its place, as a saucer might adhere to a cup. The upper surfaces of the clouds are by no means level, in fact present the appearance of an undulating country covered with snow.

A slight breeze occurring cleared away the portion of clouds which covered the immense crater of Haleakala, and exposed to view what the Commissioner denominated the largest caldera known. He used this term in contradistinction to volcano, in that a caldera may be described as a pit in which numerous volcanic cones have been formed.

The Commissioner purposed visiting the floor of the caldera, from which journey some of the party excused themselves, as the ascent therefrom would be more of a task than their weak lungs could stand. The atmosphere, at this elevation, is exceedingly rare, and some complained of nausea.

It was arranged that our hero should accompany the Commissioner and another member of the party, the guide offering to take charge of the horses. The balance of the party proposed securing some specimens of the silver sword (argyroxiphinm Sandwicense), which is found only at this elevation. Flocks of wild goats also attracted their attention, and promised some good shooting.

The party began the descent into the crater, and went witl such Titan strides down the black scoriæ of which the sides were composed, that they were soon on the floor. Many of what appeared to be sand-dunes from the top of the mountain were found to be craters, some of which were 500 feet in height. They wandered around some, and the feasibility of riding into the crater was discovered and the Commissioner determined to send for the horses and ride out on the Koolau side.

Our hero proffered to go and bring the party, and leaving one canteen of water he commenced the ascent. He found that what took but a few minutes to descend required much longer time to ascend. The rarity of the atmosphere, which made exertion 
difficult, the great heat of the sun, from which there was no shelter, and the ever-moving scorix, made his task a hard one. However, Yankee grit "will get there," as the boys say, and he was soon on the summit. The party refused to go farther with the Commissioner, and taking the guide with them left our hero, with the water, provisions, and three horses.

Riding round to the entrance of the opening, and leading the other horses and baggage, he finally reached the party on the floor.

They now started for the windward side of the island, through the crater, and having reached the Kaupo gap at an elevation of 7600 feet, were forced to camp. The lack of water for the horses was the only drawback. There is a hole where water may be found at most seasons, but they were unable to discover it. Bright and early in the following morning they hegan the descent, and after riding through a most precipitous country arrived at the sea. Turning easterly they arrived at Hana long after nightfall, the whole party badly used up.

The Commissioner kept up the interest in the ride by calling attention to the peculiar formation of the innumerable precipitous gulches which they crossed, the great tree-ferns with their weird and wonderful fronds. The sides of these gulches or ravines were densely covered with vegetation, over which climbed the ieie, wiîd nasturtiums, and convolvulus vines. Many mountain-apple trees were seen, peculiar in that their magenta blossoms grew immerliately from the trunk or large limbs rather than from the ends of branches. The small valleys in those ravines all appeared to have more or less signs of cultivation or of having been cultivated. Several native houses were passed, the inhabitants invariably inviting the travellers to rest and eat. At one house, newer than the others, they took lunch, the native preparing chicken in a marvelously short time. Here the gentlemen submitted themselves to the operation of lomilomi, which they admitted was very restful. It is merely a kneading of the muscles by hands which are accustomed to the operation.

At Hana the gentleman with the Commissioner decided that he could not undertake a return journey, and they agreed to return in a boat to Haiku. They directed "Kansas" to lead the horses back to Makawao, and he started away by the lower road through the Koolau country, arriving at Makawao after a two days' journey of danger and difficulty. Crossing many of the streams was very risky at times, as those streams were subject to sudden rises 
of water, and there were no bridges. He felt thankful for a safe return, and vet amply repaid for all his care and anxiety by the store of knowledge he had acquired, not only from the Commissioner and his companion, but from the knowledge of that well watered country, the sources of whose streams he had witnessed. He hari also made the acquaintance of the Commissioner, which was not only renewed in a few days, but which in after years in Washington proved mutually agreeable. 


\title{
CHAPTER XIV
}

\author{
PHASES OF PLANTATION LIFE-NATIVE LANGUAGE AND LORE-
}

NATIVE DIVISIONS OF LAND-DYESTUFFS USED

BY THE HAWAIIANS.

$\mathrm{O}$

UR man was sent, the boiling season being over for a time, into the fields with a gang of men to clear away the fields and prepare the rattoon or volunteer crop. The fields were run over with fire and all the superfluous leaves and weeds destroyed and the cane given a chance to again sprout. As this plantation was not under irrigation, and the cane was planted at different elevations, some of it was ripe whilst other parts were just being planted. With a gang he undertook stripping, which is one of the hardest jobs on the plantation, not only on account of the extreme heat in the center of a field, but from the sharp serrated leaves of the cane whose edges cut like a saw and knife combined, when by accident the leaves are not properly grasped, or a jerk of the arm throws the back of the hand against a projecting leaf. He worked as faithfully at this stripping as at any other work he had been set at, and soon found that by attacking a stalk systematically and grasping the leaves firmly from the base upward, they all came away freely.

He saw the utility of the work, for the eggs of the borer could be seen in many a leaf stalk ready to be hatched and get in its deadly work on the cane. Also, the cane appeared to thrive better when the effete leaves were removed and the wind had an opportunity to clear away the hairlike fungus which covered the stalk at the base of the leaves. The natives jeered him, and challenged him to race across the field. He found that he could not compete with some of the older hands, who were adepts at the work, and with one sweep could clean a stalk. Still he persevered and soon became quite quick at the work. The leaves, being stripped, were thrown in between the rows, and after the cane was cut fire was allowed to run over the field, cleaning it of all trash and vermin. In this our agriculturist felt that a great waste was committed, 
for although the ashes was a very good complement to the soil and the fire a grand vermin exterminator, he contended that it would pay well to carry all to a small valley and there make a great pile of compost against planting time.

It was noticeable the rankness with which the cane grew in certain valleys where the rains were slow in percolating the soil, also on some slopes where the actinic rays of the sun could operate to best advantage. He frequently studied out what would be the difference in the total crop of this plantation if water could be obtained to put it all under irrigation. He had made frequent Sunday excursions into the woods, or wet country, on the windward side of the island, and had crossed the innumerable valleys, both above and below, which lay between the plantation and the Hana district, and had noticed the loss of water in those ravines by percolation. He came to the conclusion that by tapping those streams at a good elevation water could be brought round to the leeward in supply only limited by the aqueduct, and probably sufficient to irrigate ten times the land under cultivation, and make the aggregate product four times what it was. He kept his counsel against the future, but his Yankee brain was at work.

He had now worked ten months on the plantation, and felt competent to fill any position. He had very little company on the ranch among the employees, as the hands cared very little for the work or improvements in it. Still, some of them passed their evenings at his cottage, and made use of his numerous papers and magazines. Whenever any fancied improvement could be made he had made note of it in a memorandum book carried for that purpose, a custom which he had pursued for many years. He believed in nailing a passing thought, and in enlarging upon it when writing up his daily journal. When he heard a new word amongst the native hands he invariably looked it up in his dictionary, and this course improved his knowledge of the vernacular in a remarkable degree, and in after years proved of great value to him.

The native language was the medium of conversation between the Chinese and other laborers, and a perfect knowledge of it was necessary. He had systematically and diligently studied it from the time he first met the preacher at Wailuku. He had procured a phrase book, a grammar, and a Hawaiian-English EnglishHawaiian dictionary, and being acquainted with the Spanish and French languages he easily acquired the proper pronunciation. 
Still he always felt that he had learned more from the New Testament, which was printed in parallel columns of Hawaiian and English. It had been translated from the Greek direct, with which he was also familiar, by a master hand, and by the time he had read it through he was spoken of by the natives as one who spoke their language as fluently as they did.

He often surprised the younger generation by using words with which they were not familiar. He learned many of the meles, or chants, from the elder Hawaiians, who had received them from those whose duty it was to learn and pass down the genealogies and history of chiefs by song and saga. $\mathrm{He}$ was surprised at the extent of the vocabularies of some of even the common laborers who went with him to the woods. They could tell the name of every tree, plant or weed that grew there. They could enumerate hundreds of kinds of fishes, some of which had different names at different ages.

When it became bruited abroad that "Kansas" was a Hawaiian scholar, his company was sought by some of the chiefs and kahunas, or doctor priests. At the house of a chief named Hikiau, who had been a warrior and favorite of Kamehameha, he frequently met some of the old-time people who freely discussed with him the arts and sciences of the ancient Hawaiians. They described their weapons of war, and from what woods made, and where those woods were obtained. Also the woods best adapted to the manufacture of culinary vessels and for the few agricultural implements required.

Their knowledge of the medicinal properties of certain herbs, and of the vegetable poisons, was quite extensive, of which he invariably made note. He was much surprised to note their knowledge of dyes and pigments used in dying their cloth and in painting their canoes, etc. To illustrate their knowledge of paints, his notes show that to make oil they expressed the kernels of the kukui nut by means of a lever. The residue was burned and the dense smoke arising therefrom was caught in an inverted calabash, from which came their fine lamp-black. In tatooing they used the green juice of the covering of the kukui, mixed with the pulverized carbonized shell of the same. This made an indelible black. For a yellow dye the turmeric root was used. Certain flowers were used to obtain the bright pinks and reds, although by no means lasting. Sepia from the squid was also used as a 
dye. To dye black they frequently steeped the kapa* (made from the wauke) in taro patches, the oxide of iron therein contained giving them a permanent color.

These discussions with the natives were exceedingly interesting, and he seldom passed a Sunday afternoon without learning something of the wisdom of the natives. Their divisions of land were so peculiar that he made diligent study into the origin of title to real property, and even took the trouble to visit, in company with one acquainted, the crater of Haleakala to see what was the matrix from which the boundary lines of all the divisions of East Mani were obtained. It was a large flat stone, called Pohakupalahalaha, the cracks, natural or artificial, radiating from the center of which, on being extended, were held to be boundary lines for the different ahupuaas, as the divisions were called. It was a remarkably simple division, and as it had supernatural authority for its embellishment, was respected by all. Thus germinating at a single point in the center of the island, and widening out at the sea, there was given to each chice and his tribe a land which would supply all the simple necessaries of life. At the seafront he had his fishing rights; a little above land suitable for cultivating taro and sweet potatoes; then the woods for his yams, canoes and fuel; farther up his indispensible ti land; then his hardwood land for weapons and domestic and asricultural implements: then his wrass lanel for thatching his house; and finally the land of the fractrant sandal-wood for barter. In the bordering ravines grew the bamboc, so useful for house building and for fishing purposes, as well as the watuke and olona, $\dagger$ from which he made his cloth, twine and nets.

The ancient tentre of real property was very insecure and depended largely on the whim of the chiefs who, with their satellites, rode rough-shod over the commom people. "Hemo ne." (you are out) if said by a chief would throw a man and his family onto the world from lands they harl occupied for generations. The feudal system prevailed in all its severity

\footnotetext{
* Kapa, a cloth (sometimes called tapa) made generally, from the inner bark of the wauke, a species of the mulberry.

+Olona. a shrub, the bark of which when dressed resembles bleached hemp or flax, and is made into small cords. Olona is also the name of the cord itself. The name is also given to animal tendons or ligaments.
} 
and absoluteness. Of course all this was now changed since the Great Mahele, or division of lands under Kamehameha III. He called on all chiefs and commoners to bring in their proofs of ownership or of residence and cultivation, and give them up to him; he then issued Royal Patents to such as made satisfactory proofs of title by prescription, they paying into the treasury a commutation and the cost of surveying. 


\section{CHAPTER XV}

MORE HAWAIIAN LORE: LAND TENURE-TABU SYSTEM-PRIMITIVE TOOLS AND PATIENT LABOR-WHERE FELL THE

CHIVALRY OF HAWAII.

$\mathrm{T}$

HE titles given at the Great Division of lands were allodial, that is, free from military burden and other service to an overlord or chief, excepting such taxes as the regular legislature might impose, the government, however, reserving any minerals which might be discovered. To the chiefs were granted such ahupuaas or large divisions as they had inherited or possessed, excepting such lands as had or would be awarded to the common people within the peripheries thereof.

Many chiefs induced their people to refrain from applying for lands, promising to allow them to live on them for ever. At the same time a law was passed that in event of the grantee and his heirs dying out, the small lands should not escheat to the government but to the owner of the ahupuaa in which they were situated.

Islands were divided into districts, mokus, ahupuaas, ilis, kalanas, kuleanas and leles, and in Honolulu into house lots.

Fishing rights were another peculiar feature of the ancient government, and many such remain to this day. A chief would claim a certain fish amongst all which frequented the waters opposite his land, and when the fisherman brought in his catch the konohiki, or agent of the chief, would insist on that one kind of fish as his perquisite. Otherwise the sea was open to all.

Again the king took all the flotsam and jetsam which came to the coasts of any part, and whale bone or teeth was his especial perquisite.

The tabu system was very onerous and burdensome on the people. A particular bird would be ordered to be tabued to the king, or a chief, and woe betide the bird-catcher who did not make returns of all such as was caught by the bird-lime 
smeared on the trees by him. Women were not permitted to eat many things that it was proper for men-as pork, fish of some kinds, bananas, cocoanuts, etc. Of course, they did do so, but had to do it surreptitiously, and many were put to death when informed on by enemies.

The men did most of the work of cultivating and preparing the food, and in this respect differed from the Indians of North America. In fact, women, amongst the Hawailans, stood on a higher plane than among other races.

The origin of a distinction between chiefs and commoners was told to "Kansas" in this way, viz.: that originally all men were chiefs and some fell from their high estate and became vagabonds and servants or slaves amongst strangers, and multiplied. This is the opposite of the white man's theory, viz.: that all were commoners, but by physical superiority some succeeded in getting their fellows down or to cause themselves to be looked up to.

The konoliki of the chief would ruthlessly take the poor man's pig or fowls without any thought of remuneration, and his taro would be sequestered whenever it pleased the chief or his satellites to take it. A man could never know what was his own, whether it was his wife or daughter, animal or product of his labor. Notwithstanding all the hardship which the people endured and the absolutism under which they lived, they throve and multiplied and probably would have kept on doing so but for the advent of the white man and the introduction by him of disease, rum, a superficial demand for luxuries, and the breaking up of their homes.

When first the white man came he found the natives a hospitable, friendly race, willing to be led to the right and respecting the superior wisdom of the stranger. They are still a hospitable, kindly people, who are in no ways malicious or vindictive.

One of the phases of life amongst the ancient Hawaiians was their indefatigable perseverance and application in working up tools, weapons, and culinary vessels from the hardest of woods with the simple instruments of stone which they had. A certain quality of flint was found on the higher elevations on the mountains of Hawaii and Maui, which they deftly split and tied to the fork of a small branch of a tree and used as an adze. This was their main tool, and with it was. fashioned the remarkably symmetrical calabashes and canoes so largely used by them. In cutting down the im- 
mense trees from which their canoes were made, the labor, with such instruments, was enormous. Stone axes and poipestles were, by these flint adzes, fashioned from hard volcanic stones, as well as maika * stones, which they used in a favorite game.

When an enemy conquered a part of an island and felt they could not hold it, they ruthlessly destroyed any fruit trees, as the cocoanut or breadfruit. This was an enormous task, but they would sit around the bole of the tree, as many as could get near it, and the incessant tunking at it with their blunt instruments would bring the monarch to the ground. As a sample of rude barbarism this is only excelled by the modern bombarding of cities and the destruction of the homes of noncombatants of our day.

The canoes and calabashes, having been shaped by the rude tool, were finished by hand. Pumice stone from the volcano was used to rub down the inequalities left by the tool, and shark skin, and breadfruit leaves were used for the final polish. These calabashes were so symmetrically made, that although round bottomed they could be filled with water without tilting. Better work cannot be done on a lathe by an experienced turner.

Printing by moveable blocks was well understood by old Hawaiians. That is, innumerable blocks with exceedingly beattiful designs, were kept by experts by which they applied rare patterns to the quilts and cloaks or capes of the chiefs. Our hero has seen hundreds of these printing blocks, and learned from the natives the pigments used by them in making the colored inks which they applied in making the beautiful patterns on those garments. Some were oil colors and others water-colors, both of which were prepared by rubbing up the pigment between smooth stones, and then, mixing with either water or oil, they were applied in the same manner as we have seen wallpaper manufacturers apply their designs by hand. A native friend of "Kansas" had a large collection of these beautiful designs, which evidently had been made not only by natural artists but by an infinitude of labor from bamboo or hard woods.

* Maika, was a name given by arcient Hawaiians to a round, smooth stone, and to the game in which it was played. The stone was also called ulu or olohu. The game required much muscular exertion, and the result was wagered upon. 
Those skilled in carving or sculpture were much respected by the masses, and had the appellation "kahuna kalaiwaa," or one skilled in canoe making or other such work, and were supposed to have occult powers.

Our hero asked such a one if he made gods. He replied that formerly he did so but now he could not do it. On being asked if there was no more demand for such, he answered that some people still came to him, men who were kahunas and lived on the superstitions of the credulous.

He said "that all the gods of the ancient times, whether made of wood or feathers, or of stone, were ugly and fiercelooking gods, and their power lay in the teachings of the priests, who said they were angry or would be if any taboos were broken or if they were opposed by any one. Our God, said he, cannot be angry, he is a God of love. It is therefore impossible to make a god which will be angry, as there is no such thing. God made us all and he loves us the same as we love and admire anything that we make with much labor, and it would be only laughable to try to impersonate a being so pleasant and who dwelt in the hearts of all his creatures."

"Kansas" was surprised to hear such expressions from a kanaka, probably a grandson of a veritable pagan, but as he came nearer in thought to the people he found that the teachings of the missionaries had taken a deeper hold on them than many gave credit for. Having been brought up a Puritan, he had been taught to fear God, and the threat of hell had been constantly held up before him, and lo! and behold, arvay out in the Pacific he was learning a broader religion.

To revert to canoe making, which was the largest industry among the ancients: When it was determined to make a canoe a skilled man was brought into the woods to select a tree. Naturally he used a certain amount of incantation to impress upon the people his supernatural powers, but in reality he was shrewd in many ways. He would select a tree suitable, first in being capable of being removed when the work was complete. Secondly, one which was sound and of the proper length in the main trunk; and of several would take the one which was the easiest to work at.

In the tropical forests all large trees are covered with parasitical climbers, the cutting away of which with the rude intruments they had was almost as much labor as to fell the mammoth. This done, while as many as could get near the 
base hewed at it with their stone axes, others were above working on the immense limbs. They made it fall in the proper direction by hauling on it with ropes made of the ieie vine -and then the real work began.

Only on some kinds of wood was fire used to gouge out the interior; the main work was done with the flint adzes both within and without. When finished and painted and to celebrate the great work, a feast followed, as we celebrate a birthday.

If we can imagine the immense fleet of canoes which Kalaniopuu brought from Hawaii in his attempted conquering of Maui, and which was said to be so enormous that the fourmile beach between Makena and Kalepolepo was not long enough for each canoe to put its prow on shore, and the men had to climb over the canoes which could touch, we can have some idea of the huge canoe-building enterprise which preceded the formation of this armada. Singularly, this armada was even more disastrous to its promoters than the fate which met the Spaniard in his attempt to subjugate the Anglo-Saxon, for here fell the chivalry of Hawaii, from which shock it never recovered. Six hundred chiefs fell in one battle, and with them perished much of the learning and glory of the ancients.*

* Kalaniopun, King of Western Hawaii, was born in 1752. In 1778 he waged a disastrous war against Kahehili, King of Maui, and Kamehameha then fought as a soldier under his banner. Kalaniopuu died in April, 1782, leaving his kingdom to his son, Kiwalao. About three months later, in a battle between Kamehameha and Kiwalao and his party at Keomo, Hawaii, Kamehameha triumphed, Kiwalao was slain, and Keona became King of Kau and Puna. 


\section{CHAPTER XVI}

THE HAWAIIANS: WHENCE CAME THEY AND THE FLORA OF THEIR ISLANDS?-THEIR KNOWLEDGE OF MEDICINE AND SURGERY.

"VANSAS" having studied botany in connection with his

business of gardening and nursery keeping, was probably more interested in the flora of the islands than the ordinary visitor. He noted the great number of trees and plants found on the islands which were similar to those growing on islands at great distances toward the South and West. This group was isolated by nearly 2000 miles from the nearest islands of the Pacific and from which these fiora must have come. They had evidently been carried by the people in olden times in their migrations, as otherwise their presence could not be accounted for.

He had learned from the song and saga of the natives that the first immigrants had come up from the Southern seas. They had evidently brought with them such seeds or cuttings of useful trees as they had been accustomed to, and whose qualities, medicinal or otherwise, were requisite in their domestic economy. The cocoa-nut, probably the most useful to all savage races of all the fruit trees, could by no possible current have been carried to these islands.* The same could

* This positive statement is open to criticism. It may be a fact that cocoanuts were brought to these islands by people in boats, and that none ever drifted here in ocean currents; still there seems to be authority for the statement that boats adrift at sea have been brought to these shores, by wind and currents, and if boats why not cocoanuts, or any other flotsam? There is a legend that in early days a Japanese junk drifted ashore at Waialua, on Oahu; and so late as 1898 a little schooner from Tahiti, the "Tetautua," which tried to make Penrhyn from Seilly island, lost its course and reckoning, if it ever had any, and landed at Hookena, Hawaii-more than 2,000 miles away-a strange land to the people abroad. (Vide twelfth report of the Hawaiian Historical Society). Information obtained from a legendary source may be taken with a "pinch of salt" "; this applies to the junkstory, of course, but it also has relevancy to the flora, and people, that were on these islands when written history commenced. In other words, legends stand as we receive them, often, only because we are unable to disprove them. 
be said of the bread-fruit, a seedless tree, only propagated from shoots from the roots.

The dissemination of plants and trees amongst the various atols, islands and archipelagoes of the P'acific is accounted for in many ways, principally by currents, winds, birds, and lastly and perhaps greatest, by human means. Very favorite trees as the kou, milo, hau, kamani, kukui, ti, wauke, ohia, ai; and amongst plants the sugar cane, yam, pia, awapuhi, olona, banana, taro, ape, uala, calabash, bottle-gourd, and awa or piper methy'sticum, are such as have no doubt been brought by the original inhabitants.

The study of botany and the affinity of those on the Hawaiian Islands to similar growths found elsewhere, may be of some aid in tracing the origin of this peculiar people. Others have endeavored to trace their origin by studying and comparing their language, manners and customs, religion, and similarity of habits with peoples of continents or other groups of islands, and have concluded that their ancestors came from Asia through the chain of islands running southeast from India to Australia.

The discovery of the Hawaiian archipelago and the migrations which have followed would conclusively prove that a greater knowledge of navigation and astronomy was possessed by the ancients than we have given them credit for. All immigrants have named new localities in accordance with names in the beloved land from which they emigrated. In America we find Plymouth, New Bedford, New Orleans, Nuevo Leon, etc., and by this means it is possible to trace the origin of the early settlers of those places, even should literature be utterly destroyed. We find in Hawaii names of districts similar to those in the older islands of Java and Sumatra, such as Hawaii (Java-iki), Hamakua, Koolan, Waimea, etc. The fact of finding so many trees and plants similar to those of the East Indies, which by no natural means could have been carried to this distant, isolated group, would confirm the impression that the Hawaiians emigrated from that part of the world.

"Kansas" delighted to make use of his Yankee inquisitiveness, and make inquiry as to the names and various uses each plant or tree was put to by the natives, and was continually surprised to note the great knowledge they had of the flora 
of the islands. Naturally, amongst a people so circumscribed as the Hawaiians, and whose horizon was so limited, their attention would be turned to the resources of their own country.

Every thing that was edible was known to them, many of which without the action of fire or condiments would be deleterious. Emergencies had caused them to use plants that otherwise would not be eaten. Thus we find that the root of the tree-fern was in times of famine resorted to to sustain life. From the fronds of some fern a succulent greens was made. Taro, itself, without cooking is extremely acrid and poisonous. In a raw state, when grated, they used it as a medicine. Vessels of clay they had not, and the only thing that would stand fire was the cocoanut shell, wherein by dropping hot stones into the water, boiling water was obtained. Baking in ti-leaves and the large leaves of other plants was admirably conducted. Salt was made by evaporating sea water, and sometimes this was done by carrying the water in calabashes to great distances and there evaporating it.

Clay (Hawaiian equivalent, "palolo," sticky mud, adhesive dirt) was much used in surgery in putting the broken limb in a case and wrapping the whole in leaves. They boasted of their great success in this line. It certainly is a great antiphlogistic, and their action has been followed by our own surgeons. The juices of some fruits, as the noni, were used as remedies to prevent the falling of the hair.

The astringent and laxative qualities of many roots and herbs were well known, and the kahunas practiced medicine successfully, although such practice was accompanied with considerable humbuggery and many incantations. Like Christian Science believers, they considered it necessary to first obtain the confidence of the patient and then treat his malady, although, unfortunately, some of the believers in Christian Science would attempt to cure without using the remedies which the Creator has placed in their hands.

It would not be wise to attempt, in a book of this nature, to recite all that "Kansas" learned of the medicinal virtues of herbs and plants known to the Hawaiians, hundreds of which he made note of. They were frequently inclined to invent stories for his edification, and it was thought great fun to give false information in the matter of the uses of vegetable products. 
Life, to a native, appeared to be one round of frivolity, and it was rarely that one was met who gave a thought to the future or to laying up a contingency against a rainy day or old age. Life in the tropics is notorionsly easy, and in the old times, when wants had not multiplied, the cultivation of a small tract was sufficient to supply food for a large number when eked ont with the products of the sea, in the taking of which the natives were adepts.

In another chapter a somewhat lengthy account will be given of the food stuffs of the islanders and of the manner of preparing them. "Kansas," for his own amusement, edification and pastime made a study of the prime necessaries of life among the people, as well as of their knowledge of the arts and sciences prior to the advent of the foreigner. To this he had added the acquired knowledge of the working of the feudal system, and of the origin of the titles to real property. The study of these matters brought him into close relations with some of the most advanced of the natives, and a great increase of his knowledge of the vernacular, all of which proved of much value to him, as we will notice in future chapters. 


\section{CHAPTER XVII}

HAWAIIAN HOSPITALITY AND CUSTOMS-PAGEANTRY OF A ROYAL TOUR AROUND THE ISLAND OF OAHU.

H ERE the author takes the liberty of inserting a chapter which has appeared in the Commercial Advertiser, and which, although written by himself, was said to be the best pen picture of Hawaiian hospitality and customs which has appeared in print. The edition was soon exhausted, there being many demands for it to send abroad.

Editor Advertiser:-I hand you herewith a description of a tour around the Island of Oahu as told to me by my friend, the Hon. John A. Cummins (one of the last of the Hawaiian Chiefs), which I am sure will be of interest to many of your old-time subseribers, and also will show the malihinis how the Hawainan entertained.

Yours truly,

JAs. W. Girvin.

On October 10th, 1875, I received a letter from Her Majesty Queen Emma, stating that she wished to see me. As I had opposed her election and she knew I had been very instrumental in securing the election of H. M. Kalakaua, on calling at her house I was agreeably surprised at the pleasant reception she gave me. However, her husband, the late King Kamehameha IV, and I had been schoolmates and intimate friends, and during his reign I frequently entertained him at Waimanalo, and on more than one occasion I had the opportunity of doing some kindness for Her Majesty. She made no mention of the past opposition to her, but asked me to accompany her on a tour around the Island of Oahu.

I had always honored and respected Her Majesty above all the Princes it had been my fortune to meet, and I have known all from the days of Kamehameha III to the present time, and I resolved to make her tour of the island one of great pleasure and comfort to her as well as one of note in Hawaiian history. I am also a chief, descended on my mother's side from 
the same line of chicfs in Puna, Hawaii, from which sprang Kamehameha I, and Kalakaua.

Being familiar with the sports of the Hawaiians and somewhat posted in Ilawaiian mythology and occult mysteries, as well as being an adept at fishing and the preparation of the foods of the people, I knew I could make her tour a pleasant one. At that time I had considerable resources at command, being the konohiki, or lord of Waimanalo, and owner of hundreds of horses and cattle.

The Queen asked me to fix a date convenient to me for the beginning of the grand tour, and requested me to take charge of all the details of the procession.

I decided that Guy Farves' Day, the 5th of November, should be the day of leaving Honolulu. Notices were put in the papers and also posters sent to prominent parties in different parts of the island, fixing dates at which the cavalcade would arrive, and I endeavored to meet all those arrangements.

On that day, in riding down Nutanu avenue from Waimanalo at $6: 30$ a. m., I saw a great many men, women and children carrying baskets and bundles of leis, some of ilima, some of marigolds, some of lehua blossoms and of ahilni done up in wrappers of ti-leaf and banana; lei lehua ahihi woven with maile, hala fruit leis done up in solid bundles as pai-ai or hard poi is put up, all being carried to their gracious Queen Emma.

I had breakfast with Her Majesty and her mother, at which were present Peter Kaeo, Kunuiakea, and other high chiefs, at 7 a. m. At this hour the city and surrounding country were cosered with mist and a light rain was falling in the valleys, and as the sun shone on them innumerable rainbows and in some instances double rainbows were produced, which some prognosticated to indicate an auspicious commencement of our pageant.

I had brought in some of my best horses, and gave Her Majesty an animal of fine pedigree named "Kekonikauaikanahele" for her sole use, and which she rode throughout the journey. He appeared to realize that he was carrying royalty, and, although cavorting from side to side and making as much of an exhibition as a good horse can do, he was as gentle as any lady could wish. 


\section{Kulionou and Makapuu.}

After breakfast the cavalcade was put in order. It consisted of one hundred and forty women, riding astride, dressed in the brightest colors the stores of Honolulu afforded. The pa-u or riding habit of the women consists of a long piece of bright print wrapped around the hips and extending down to the stirrup, from whence it flares out behind when the horse is in motion.

The impression as we swept through the streets on our dashing horses must have been gorgeous. Her Majesty and myself led the procession, followed by her mother and other chiefs. The streets of Honolulu were thronged with people to witness the grand sight, and it would appear that the whole city and many from the country had turned out to see the departure. We rode down Nuuanu street and along King and up into Beretania and thence out towards Kamoiliili. At Kulionou we were entertained at luncheon by Mr. and Mrs. Pico. They had provided all the luxuries to which foreigners are accustomed, and also a magnificent native luau. The food was exceedingly plentiful and much more than was necessary, even for so large a number. We got away from there at 1 p. m. and rode down across the plains of Kaea, Kamehame, and along the paved way to the foot of Makapuu.

On Makapun point stood the hula god Malei,* which was duly saluted, and we descended the precipice. Here the royal party saw a sight such as they had not expected, and such as will never be seen in Hawaii again. Six mounted knights in red costume and red visors, carrying torches, presented arms to the Queen. As the procession wended its way onward every three hundred yards an arch bearing a motto in the Hawaiian language presented itself, welcoming Her Majesty to the Koolaus. No two of these mottos were alike, and some were from the ancient hidden tongue known only to the chiefs. These letters were constructed of combustibles and burned until the whole cavalcade reached my home-place, "Matına Rose," a distance of four miles.

\section{Waimanalo.}

All the arrangements for welcoming the Queen had been made by me or through my orders. Her arrival was welcomed by a

\footnotetext{
* A modern, powerful United States lighthouse stands there now.
} 
corps of men blowing horns made from lauhala leaves. All the residents of the neighborhood had assembled to see their beloved Queen, and as she passed lay prone on the ground out of deference to old Hawaiian customs, although such usage had passed and was not expected of them by Her Majesty.

I had erected two very large lanais which were covered with cocoa palm leaves, either one of which would have seated 200 guests. At 5:30 p. m. Her Majesty, the chiefs, and the whole party sat down to a feast of all the good things of which the Hawaiians are so fond. At $8: 30 \mathrm{p}$. $\mathrm{m}$. the luau was over and the hula began. I had made arrangements for illuminations and fireworks, and rockets were fired from the precipitous mountains in the rear. Blue lights and other pyrotechnics enlightened the heavens and made the night brilliant, and three hundred torches burned throughout the night. Three sets of hula dancers and singers relieved each other through the night, and daylight found the hula still fresh. This entertainment lasted three whole days and nights. At $\&$ a. $m$. two tables sufficient to accommodate two hundred guests were spread for breakfast. The preparation of poi, fish of many kinds and served in many forms, as dried, lawalued, fried, boiled, etc., had occupied the services of several good stewards, and good stewards among the Hawaiians are adepts at such luaus.

Among the good things Hawaiians relish most is limu, or sea-weed, and at this luau a great many kinds were served, to mention the names of which would only be confusing. Naturally foreign delicacies were not neglected, and tea, coffee, chocolate, cake, bread and butter, meats of all kinds were served in profusion as called for at each feast, for it was a round of feasts. After breakfast, on the first day, all parties proceeded to amuse themselves in such manner as life in the country afforded. Probably half of the party went to the mountains to gather maile, awapuhi, ohawai, palapalai and hala fruit to make leis for the afternoon. The other half remained at home; and I prepared some rare fishing sports. It was a great day with the fishermen, who excel in that part of the island.

Quantities of fish of many kinds were caught. Amongst these were honu or turtle, ula, opihi, okala, uhu, palani, hee, ohua, manini, kumu and others. Fisherman Malokea, and his large gang of men and women with sweeping nets caught lots of moi, sandfish, akule, and others, the sweepers covering a distance of 
five miles of beach from Muliwaiolena to Putkiloia. Her Majesty and most of the party had a sea-bath and witnessed sports on the water before returning to Mauna Rose.

\section{Puewai of Puha.}

In the meantime I had a gang of men at work preparing to open the bar at the mouth of Pula river. This bar or dam had accumulated for some years and much water was backed up. I had seen this opened on a former occasion, and the sports of the natives in swimming the raging waters, and determined to give Her Majesty and party a view of this ancient sport. To this end I had a gang of men cut and carry away much of the embankment so that but little would be required to bring down the flood. An opening of 20 feet or more having been made in the dam the water rushed out at the rate of 30 knots or more. The bore or surge caused was very high, and only two men and two women dared to play on this water-surf, called Pue-wai. One strong man of fine form went across and back holding up the tip end of his malo. This was the grand sport of the day and was the subject of comment by all who witnessed it. Her Majesty presented each of these four with \$IOO and four pair of red blankets. "Hee-Pue-Wai" was a bye-word for several days thereafter.

At 4 o'clock p. m. the whole party, augmented by many from the Koolau district, sat down to a bountiful and elaborate dinner. Four chief stewards looked after the welfare of the guests and two chefs de cuisine took charge of the foreign part of the entertainment. Amongst the provisions prepared were ten hogs, one whole bullock cooked in different styles, ducks and turkeys in quantity, also fish of all descriptions served in as many imaginable ways. During the night one table was kept supplied with food and drinkables. On the second night the bonfires on the mountains were kept up all night.

The second breakfast was not so well attended, many of the guests having indulged too freely in fresh pork.

On the 7 th I decided to give an exhibition of my trained horses, and other sports were also introduced at Hunananiho. I had then eleven horses under training, all of which were thoroughbreds; and four jockeys. The races were very good, and as Hawaiians are lovers of the sport the whole party had a rare treat. 
Every day while the Queen was at Waimanalo large quantities of fish of all descriptions were brought in. Her Mlajesty was in good health and entered into the joys of the people, riding and driving around the country. I tanght her to use the ritle, and she did some excellent shooting, on several occasions smashing a bottle at ifo yards, and conld cut a twine with a rifle ball at a long distance.

The people from all parts of the Koolaus kept arriving and bringing in their hookupus, or gifts, of foodstuffs. New hula dancers also presented themselves as the reputation for the distribution of prizes spread throughout the island. I had to send much of the eatables away to Judge Pii's house at Kaneohe, where the next station of the procession was to be. Notwithstanding the great concotirse of people to be entertained, my work was made comparatively easy by the genial disposition of the people and the faculty Hawaiians have of caring for themselves. The presence of the Queen forbade any rudeness or undue existence of spirit, or quarreling, amongst this large number of guests.

\section{Kaneohe.}

After another grand breakfast on the eighth, the whole party being ready, we made a start for Kaneohe by way of Alele. It was a great crowd, all on horseback and all dressed in bright colors, with heautiful leis. The cavalcarle was led by six mounted knights in red with burning torches. Many people stood on the Pali to witness the course of the procession.

At the boundary of Wailea I had an immense bonfire. Here I had erected an immense arch of fire fifteen feet high through which each member of the party was compelled to ride. The arch was covered with gunny sacks saturated with kerosene and then covered with ieie vine. At high moon Her Majesty and I rode through this hoop of fire followed by the balance of the procession. We thus left the boundary of my land, and were in Kailua, from where we had a view of our own party on the plain of Alele.

At Judge Pii's house at Kaneohe great preparations for entertaining on a grand scale had been made. I had two men in charge of the three hundred torches and pack horses for the same. Two more cared for the eatables and drinkables, and four 
more bringing horses and a Concord buggy and double team of black horses. Here the hula kept up all night, and no sleep could be had.

\section{Waikane.}

After breakfast the next morning the procession took up its way to Waikane, to Mr. Kamealoha's place. I drove the Queen behind my black span and her mother followed in her carry-all. Good humor and joviality sat on every feature, and with oli and mele the procession made its way to its destination at the next station. Her Majesty appeared very much gratified at the numerous expressions of good will, and once remarked to me that if I had caused her to be elected she assuredly would have appointed me one of her ministers. I replied that although my father was an Englishman, he believed it was for the best interests of the country that there should be a king at the head of the nation rather than a Queen, and that it was preferable that American infuence should sway the throne rather than English, as we feared it would be if we elected Her Majesty. Also that I had asked her what her wishes were on a former occasion, and she had assured me that she did not contemplate being a candidate for election to the throne. Arriving at Kamealoha's place, through six magnificent arches of evergreen, we found preparations to entertain a thousand people. Her Majesty and party were here assured of a most hearty welcome. Without being tautological, I can say that the immensity of leis of hala-fruit and others that were prepared for our adornment was stupendous. To describe the great fish prepared in many styles, both raw, dried and cooked, the hogs, poultry and delicious comestibles would take more space than I can afford, although not more than the love displayed by her people deserves. Notwithstanding the immense number to be fed, the hookupus, or gifts of food, had increased the store of provisions to such an extent that from there I was compelled to send by the schooner "Rob Roy," to Her Majesty's residence in Honolulu, nine live hogs, eight bundles of dried mullet, six barrels poi, two dozen fowls, etc. Kamealoha had two large thatch houses and a large school house at his command for sleeping quarters, and had erected an immense lanai for the luau. He was a well-to-do citizen, and as gen- 
erous and hospitable as any whom we met on the grand tour. At night the torches burned and the hula went on, and joviality and free intercourse was the rule.

\section{Kahana.}

After breakfast the next day, all feeling refreshed, the procession proceeded on its way, to Kahana. Before arriving there the cavalcade passed through a region where melons grew profusely, and the residents passed to those of the party who would accept, goblets of fermented melon juice and tiroot cider, which both refreshed and inspirited them.

Here a Chinese, Apakana, and his Hawaiian wife, Mary, a sister of Kamakini, received us all very warmly and had made great preparations for our entertainment. To see two hundred horses tied out in the grounds and their accoutrements on fences and trees, alone was a novelty. This foreigner, Apakana, seemed to vie with the Hawaiians in his endeavor to entertain Her Majesty and suite in form commensurate with her rank. The feast he and his wife spread out was ample for twice the number of our party, although our numbers appeared to steadily increase. There was a plethora of poi, sweet potatoes, rice, hogs, fish, raw and cooked; more than enough for five huncled people for four days. Ifere we saw the larest oios, a most delicious fish, which we had on the grand tour. Crowds of people joined us here, some leading pack-horses loaded with melons, sugar cane, bananas, cocoanuts, dried fish, etc. Excepting Her Majesty and a few others, all went in bathing in the large river there.

\section{Punaluu.}

After a late breakfast the procession took up its journey to Punaluu. Here were three very large thatch houses. The natives there had a hui, or cwnership in common, and we remained with them two days, but were no burden to them as we carried so large a store of provisions. The hula and speech-making was kept going continually, and it was the noisiest place we found in the grand tour, eren the Chinese adding to the din with their firecrackers. The feasting appeared to be continuous. The provisions multiplied to such an extent that I was compelled to send a schooner from there 
to Honolulu with ten bags rice, ten barrels poi, ten bags sweet potatoes, ten hogs and pigs and two dozen fowls.

We left there on Wednesday morning, intending to make Lane's place at Hauula that night, and had forwarded much of our provisions and paraphernalia there. When about to start from Punaluu one of the principal natives, Keaunui, invited the Queen to take a surf-ride in his two and one-half fathom canoe. He was a very large and fine-looking man, and had a great local reputation. He had about fifty fathoms of small line and two horses, the intention being to pull the canoe just inside the breakers, parallel with the beach for a distance of four miles. The beach terminated at his house, where he had prepared a fine luau for the Queen and party. Her Majesty declined to go in the canoe with Keaunui, but said she would go with me, having more confidence in my care of her. We got out of the buggy and I purchased 125 fathoms of line at a Chinese store, and one of my boys took the kinks out of it. I had it made fast close to the fore out-rigger of the canoe so that it forced the canoe out about 100 fathoms. I had nothing on but a malo and broad-brimmed straw hat. The Queen left her shoes and stockings and got into the canoe and sat down, holding firmly by the out-rigger. The beach was crowded with people to witness the great sight of a Queen taking a perilous ride in the surf. I had two good horses at the end of the long rope and gave the canoe a strong shove cut to sea and jumped in at the same time. The horses went full speed along the beach. I turned my paddle up and kept the canoe out the full length of the rope, and the speed must have been thirty knots. Then I played with the Queen, dipping the out-rigger into the sea, which threw the spray over us, causing a rainbow to those on the beach. The Chinese left their rice fields to see this great surf-riding. In the canoe the Queen only was visible. We had the rushing of the surf and the speed of the horses to propel us, and flew through the water. Her Majesty enjoyed the perilous surf ride, although she was wet through and through when we landed at Keaunui's house. Eight strapping kanakas lifted the canoe and both of us out of the sea and carried us up to the house at Kapaka, Koolauloa. Although Keaunui had his feast ready, we had to go up to Kaliuwaa waterfalls to bathe and get the brine off and change our clothing. The natives carried both the Queen and myself to Kaliuwaa. Kekela, the Queen's 
mother, remained at Kapaka until our return. This waterfall is also one of the historical points on the Island of Oahu, about which many legends are told. After swimming, high jumping, diving and other sports in which the large crowd joined in the beautiful pool there, refreshing drinks were passed around amidst great hilarity. The pool is about fifty feet across, very cold and quite deep.

\section{Haunla and Laicmaloo.}

On our return to Keaunui's we enjoyed the great feast he had prepared. He had every Hawaiian luxury that could be desired. We left there quite late, but many of our party had gone ahead to Hauula, Mr. Lane's place. We did not arrive until 10 p. m., and the whole party were tired. I stirred them all up and got the hula people to make a noise. Mr. Lane and wife were very much annoyed at us for being so slow in arriving, as the luau had been ready some hours before. However, they got up a nice breakfast for all the next morning and we got the procession started for Laiemaloo. Here J. W. Kupau entertained us. He had eight large houses and one large lanai. At this place was the great hula man, Kapuaokahala, and his three daughters. He had the reputation of being the best hula player in Hawaii-nei. We remained here two nights and had a grand time. All the residents of the neighborhood flocked to see the royal train, and they camped out under the hau and hala trees. There was an abundance of fat hogs and pigs, beef, poultry and fish. There was much steam consumed by the camp-followers, so as to keep everything going lively. The different kinds of hula, as puniu, alaa, papa, ulinti, paili, paiumauma, etc., were witnessed as performed by this old-time hula master.

I had to take this crowd of hula singers to Honolulu with us to keep up the merriment of the party, and sent the old crowd back to their homes in Kaneohe, Mokapu, Kailua and Kaaava. This new party of hula singers and performers got the whole procession in good humor. Here the Queen bought lots of blankets and calico for the poor people, and many shirts called newahine, and gave to them after breakfast on the second day. We got away for Kahuku, where Judge Kaluhi entertained 11s. This is the land of the hala tree. We had four very large houses, and all the walks around and from 
house to house were covered with matting called ue. Every one took care of his own horse and all were welcome. The viands were most abundant. At night I had all the torches burning, which lighted up all Kahuku. Our party by this time had increased to over three hundred, and the number of visitors and friends from the neighborhood was very large.

At the midnight luau I sent word around among the people that there should be no one leaving here for Waimea or Waialua who had not a wreath of hala-fruit, and that we would leave after breakfast on the morrow. This caused a scramble to the woods in the dark to gather the fruit for the leis. By daybreak every one had a hala lei on and we got away for Waialua. Her Majesty, her mother, and I drove in carriages, but the hundreds were on horseback. In all our traveling we had had no rain, but now we struck a heavy shower near Judge Kalanipoo's house at Waimea, where we stopped and enjoyed his hospitality. He had more than sufficient food prepared for all our 300 and odd people. The weather cleared up and we got off to Waialua. Judge Kalanipoo sent two ox-carts loaded with provisions on ahead, which were left at Ukoa-makaha, Waialua, at Kaleikini's place. Her Majesty and I led the procession, but I had two of my best horsemen as out-riders, who maintained discipline. Great preparations had been made by Kaleikini, assisted by Mrs. Apakana, for entertaining the great party.

\section{Waialua, Waipo and Moanalua.}

We remained at Waialua four days. No sooner had we arrived than the natives, men, women and children, and loaded ox-carts from all directions began to arrive with their hookupus. I had more provisions than I knew what to do with. Some of these were for myself, but I passed them all over to the Queen. Amongst the hookupus was a box of white geese, marked on the outside "Keoni Kamaki." Taking it for granted it was for me, I gave it to the Queen. It developed afterwards that the case was for John Dominis, whose native name was similar to mine. I had many of my own people with me and made them care for the goods. At 8 p. m. all sat down to one of the best dinners I ever saw. After the Oueen's table was over another was set, and so on all through the night. Of course the hula kept up and was as noisy as 
it could be. Owen and John and James Holt, who owned a large ranch in the vicinity, helped very mach in arranging for the comfort of this great crowd.

The Queen had a head steward who had twenty men under him, ten of whom guarded by day and ten by night. My torch bearers renewed their stock of kerosene at every Chinese store throughout the route and looked after their work well. From Waialua I took the opportunity to ship by the schooner "Luka" ten barrels poi, ten sacks sweet potatoes, eight bundles dried anae, three dozen turkeys, four dozen fowls, eleven large hogs, eleven small pigs, four sheep and one dozen white geese to be delivered at Her Majesty's house in Honolulu, directing that there should be given from these to the King and each of the chiefs a share of each commodity shipped. The hookupus kept on coming in during each day of our stay.

The inhabitants of Waialua district were exceedingly kind to the Queen and her party. Bundle after bundle of maile leis and leis of maile laulii o koiahi. Natives from distant Waianae brought to Her Majesty quantities of their famous fine-flavored cocoanuts, called poka-i. Four days in Waialua seemed to me to be too much, but it did not seem that way to the people, as they appeared to enjoy themselves very much. Every meal was crowded with them. Bathing parties were in the sea at all times, as were fishing coteries, while others were visiting the uplands. It was curious to me to note that I had no trouble with this army of friends, but they were well disciplined and polite. Assuredly Waialua never saw such a sight before and never will again. Every surfboard in the vicinity was in use, and there were some rare actors amongst this mass of people, who hailed from all parts of the island.

On the morning of the fourth day, after another great breakfast, the cavalcade was formed for the ride towards Honolulu. It was one of the most beautiful sights ever seen, to look back on the procession from the uplands; and Her Majesty was continually looking back at the bright colored procession which followed us, four abreast. There were three hundred women with gaudy leis of bright flowers and maile wreaths, their horses also being decked out with evergreens. The horses pranced and looked well, the women looked fat and smiling and every face was wreathed in smiles. 
Only the Hawaiian language can describe the joy of the return pilgrimage. It was a long ride to Waipio, but we got there safely and put up at the house of one of the Queen's retainers. He also had a sufficiency to eat, but there was no rest, as the quarters were limited and the noise fearful. After breakfast the cavalcade pushed on to Moanalua to Her Highness Keelikolani's house, where great preparations had been made to entertain so vast a multitude which had still farther swollen by numbers who had come out from Honolulu to escort us home. An immense lanai had been constructed of cocoanut leaves, a beautiful structure. Here all the Hawaiian luxuries were ready for a final luau on an exceedingly grand scale. I never saw such an abundance of leis made of lehua blossoms, and cannot imagine where they came from. Just as the party were ready to partake of the viands a very heavy shower of rain, accompanied with thunder and lightning, fell, which drenched every one to the skin. Still we determined to sit through it. I should state that we were here joined by about two hundred people on horseback from town.

After the luau we resumed our march towards town, the Queen on "Kekonikauaikanahele" and I on "Taiehu," which was a most beautiful white horse with red spots the size of a dime. Her Majesty and the horse were covered with leis of lehua and pikaki, and every one of the seven or eight hundred were likewise bedecked with leis. We led the procession, followed by the whole cavalcade, along King street, up Richards and along Beretania to Her Majesty's house. All dismounted and bade Her Majesty farewell, and I took my men home to Waimanalo, having been fifteen days on the merriest, wildest jaunt of my life.

I am sure I have neglected to tell much of the fun that went on at each resting place, but the whole was an Hawaiian holiday according to the ancient custom of enjoyment, and it is unlikely that such could ever be repeated. 


\title{
CHAPTER XVIII
}

\author{
THE TRANSFORMATION OF "KANSAS"-FROM "SHIPPED MAN" TO \\ PLANTATION MANAGER IN ELEVEN MONTHS.
}

$\mathrm{O}$

$\mathrm{NE}$ evening, as he sat reading, the Chinese steward from the house rushed in, and in a very excited manner told him, "Mamma (the planter's wife) wanted him to go there quick, bossy he fall down dead." Our hero felt that something very serious had happened at the house, and in a few strides he was there. Here he found everything in confusion, the ladies wringing their hands and crying, excepting mamma, and she was on the floor chafing her husband's hands, bathing his face and calling for remedies, and especially urging them to send for "Kansas." When he appeared she appealed to him to save her husband.

"Oh, you can do it," she said, "he had such confidence in you and said that when anything went wrong to call on you."

"Kansas" found that the planter had fallen from his chair while sitting quietly amidst his family, in what appeared to be an apoplectic fit, and was dead from heart failure. He quickly stripped the clothing from the prostrate man's chest and anplicel his ear to endeavor to learn any signs of life. He fancied he detected a slight murmur of the heart, and some pulsation at the wrist. He used cold water copionsly, and finding life not extinct took out his knife and opened a vein in the man's arm and bled him quite freely. His patient immediately began to show signs of life, and very soon they were enabled to get him into bed.

One of the servants had gone for the doctor, who lived at a distance of about four miles. When the doctor arrived, he approved all that our hero had done, and freely commended him for his prompt action. The doctor said it was a fit of apoplexy, and it was extremely fortunate that there was some one on the spot who had the nerve and knowledge to act as "Kansas" had done, as it had undoubtedly saved the planter's life. 
Mamma said openly, "Yes, papa said that if any kind of trouble came to call on 'Kansas'; he thinks 'Kansas' knows more about anything than anybody."

Our hero felt flattered; but he had had some experience in accidents, and had read of similar cases. The ladies made remarks which showed that they had taken notice of him, although he had not had the honor of an introduction, nor of conversing with them. Mamma could not refrain from expressing her joy at the restoration of her husband from apparent death, and from her language he knew that he had often been the theme of conversation in the home.

After a few days the planter was able to be out on the veranda, but the doctor ordered that he should leave the plantation and go abroad for a year at least, saying that a recurrence of the fit would probably prove fatal. His wife abetted the doctor and pleaded with her husband to take her East, which he had promised to do at many times, although each succeeding year found him no better prepared to leave the islands than the former one. He said he would go but had no one to leave in charge of the plantation. He had depended so much on himself, that now in his emergency, there was no one whom he could leave in charge.

His wife said, "There is 'Kansas,' you say he knows everything, and you owe your life to him."

"Yes," he replied, "Kansas' would do, but it looks so absurd to put a contract laborer in charge of a plantation."

It was Hobson's choice, however. He sent for "Kansas" and made him the proposition that he take the managership of the plantation. What was his surprise when the man firmly replied that he could not do it, that he had other plans in view when his year was out.

"But we will cancel the contract now, and I will pay you one hundred dollars per month from this on," said the planter.

"Still I could not do it," said "Kansas," "I have other views and plans, and time is passing. I really came to you on an apprenticeship, and not for pay. My wife and family are looking forward to our reunion, and I have by your assistance made a thorough study of the sugar industry, and now that my apprenticeship draws to a close I feel that I must go into the business on my own account."

Here was a revelation.

"Why, where is your wife?" said mamma. 
"With our children in Honolulu, and they can hardly wait until my time is up," replied "Kansas."

"You are an enigma," said mamma; "if I had known you were a married man and that your family was in this country, I should certainly have insisted on bringing them here.

"We could not well live on eight dollars a month," said "Kansas," "and like Abraham of old, I was afraid to admit that I had a wife, for fear I would get no employment; I had tried that too often before."

"I knew you had a wife," said the planter, "for my captain told me that he had talked with her about you in Honolulu, but I did not give the matter any weight."

"Kansas," said the planter, "I will make you a fair proposition. Now bring your family here, take the home and all as it stands, carriages and all, manage the plantation, and I will pay you three thousand dollars per year for three years."

"Well, Mr. - your proposition appears to be fair, and it certainly is as good as forty-five hundred dollars a year, but it is your proposition. Here is mine: You are content with your present receipts, are you not?"

"Yes," said the planter.

"Now," said "Kansas," "I propose to accept your offer, with the addition that you give me, besides, fifty per cent. of all I shall raise in excess of what you have done during the past season."

"I accept the terms," said the planter, feeling that he was dealing with a stronger mind than his own.

A lawyer was sent for and a contract, embodying the specified terms, was drawn up and executed in duplicate. First the original contract was produced and cancelled. The planter's wife begged "Kansas" to give her the contract, as she wanted to have it framed. "Oh, no," said our hero, "that represents eleven months of servitude, and my wife will prize it more than you."

He then went to Honolulu to get his wife and family, and he could not help feeling the vast difference between the cabin fare and comfort as compared with the trip of misery he had on deck a year ago. The meeting with his wife will not be described. She could hardly realize that this sunburned, swarthy man was the same individual she had taken for better or for worse so many years ago.

She was now to rank as a planter's wife, and his draft was 
to be honored to the extent of thousands. How did it all come about? She felt that all their cares were ended, and that he only received a just reward of merit. He knew that they were only at the foot of the ladder, and that years of labor and care were ahead of him.

After a week's stay in Honolulu, where they purchased such necessaries as would be needed, and where he presented his letters of introduction to the agents, they took passage for $\mathrm{Ka}$ hului. They were met by the planter with carriages and driven up to the ranch. They were the cynosure of all the beach-combers of Kahului.

"Wall, I swow," said one old blatherskite, "if that ain't H's bullock driver."

"I'll be jiggered," said another, "if you couldn't knock me down with a feather."

All united in saying that he was a hard-working man, and as smart as a steel trap; but they seemed to think it could not be right for a bullock driver and a "shipped hand" to be elevated to the position of manager of a plantation. One said he was a millionaire in disguise, and had merely played it on the old man to acquire a knowledge of the extent of the resources of the plantation. Another said that he had bought the plantation, and that Farwell, who made out the papers, had said as much as that.

The planter and his wife welcomed "Kansas" and his wife and the two families became quite intimate during the interval prior to the departure of the old planter and his household on their long journey. 


\title{
CHAPTER XIX
}

HAWAII LEADS THE WORLD IN SCIENTIFIC SUGAR CANE CULTI-

\author{
VATION.
}

$\mathrm{M}$ ARY, the old parson's danghter, came to bid the planter and his family a loving farewell, and met "Kansas's" wife and little ones.

"Oh, Mrs. H., said she, "I knew all about 'Kansas's' wife and family, and it was a mutual understanding that I should say nothing about them to any one."

"Well, Mary," said Mrs. H., "you are the one waman of my acquaintance who can keep a secret."

Mrs. H. emphatically asserted what she would have done if she had known that "Kansas" had a wife and little ones in Honolulu, and from her well-known friendly, hospitable character we can readily believe she would have taken radical measures to bring this pair together long ere this. However, they admitted that after the experience he had had he was justified in pursuing the course he did, until such times as he could have a chance of making his value known.

Many of the neighboring planters came to bid adieu to their old friends, and on being introduced to his successor they extended the right hand of fellowship and welcomed him to the society of the community. "Kansas" could not help recalling the expression of the old missionary in Lahaina, "Hawaii-nei is a country where a man finds his level sooner than in any other." The past year had been of inestimable value to him in so many more ways than if he had come in at the top instead of working his way up. Not only had his knowledge of the cultivation of sugar been thoroughly acquired, but being unharassed by the necessary interruptions of the care of a family, his general knowledge harl been sreatly expanded through his studies and observation. His acquaintance with the language of the people and the geography of the surrounding country must inure to his benefit in the coming years of his management. 
After the planter and his family had left, our hero got down to business in earnest, and the following chapters will show how he succeeded under his second contract. He knew that sugar was made in the field and that the technicalities of the mill and office were secondary. With maps before him of the fine estate of which he was the manager, and with the payroil and estimates which he had at hand, he proceeded to plan a campaign as scientifically as though it were a game of chess. He did not intend to let things go at haphazard.

That labor was becoming scarcer he knew from the conversation overheard between visiting planters, and that its price would go up was a certainty. There was therefore a necessity of meeting this dilemma. He must make the land yield more, and he must save a larger percentage of the crop. The estate was a very large one, and the question presented was whether it was not better to confine the cultivation to a smaller tract, thereby producing a larger yield, or to go on as it had been and scatter his hands over the great acreage with no larger returns.

Had the lands been under irrigation, where the rattoons, when well cultivated, are almost equal to first crop, he would have decided to put in as much as he could get water for. As the main standby of this plantation must be the first planting, he decided to merely put in the acreage that he could cultivate well, and to waste no labor on rattoons unless in certain localities where the lay of the land warranted an outlay. He knew from what he had gathered from the Commissioner's conversation on Haleakala that the whole soil was alluvion, and that the leaf mould from decayed ferns, and decomposed lava were continually being washed down by the tropical rains and would enrich the lower lands forever.

He knew of the dearth of the rains for surface moisture, but felt that he could partially correct that by adding to the soil its complement, at but a slight expense. His decision was made that he would aid nature by correcting the soil. His agents were overwhelmingly surprised to receive from him an order for a thousand tons of gypsum, to be procured at Los Angeles, at a figure not to exceed $\$ 3.50$ per ton, f. o. b. As his letter was explicit and definite, they obeyed his instructions, and in a short time his carts were carrying from Kahului gypsum to be ground and spread along in the trenches when planting. He bought a pair of French burs, formerly used in 
a flour-mill at Wailuku, and having power to spare, he set them up at the mill to grind the gypsum. Gypsum, you know, is $46 \%$ sulphuric acid, $33 \%$ lime, and $21 \%$ water, in round numbers. To a soil that was largely alluvion, made up of leaf mould and decomposed lava, lime was a complement. The action of the sulphuric acid tended to retain water that the rootlets might take up the plant food necessary for the growth of the cane.

Our readers will recall the anecdote of Franklin's endeavors to persuade his neighbors to use Plaster of Paris on their lands. Plaster of Paris is merely calcined gypsum. They ridiculed him, but one of them granted his permission to try it on a certain field of wheat. The wily old gentleman sprinkled it freely along the field near the road, and long before harvest passers could read in letters in the higher grain,

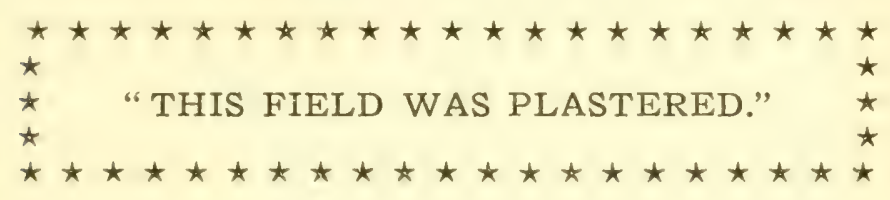

To this day every farmer in Pennsylvania uses plaster from some mine in the vicinity, and many have learned that its effect is just as good on the soil when not calcined as when it has been subjected to the action of fire and the water driven out of it.

But to the soil of this Makawao plantation the lime was exactly what was wanted. To fertilize a crop extending over so much acreage as was under cultivation on this estate would require an immensity of capital, but our hero believed it would some day be done, and in the meanwhile he determined to correct the acidity of the soil in some localities, to manure as much as possible, and to fertilize as far as he could. Towards manuring he collected all the effete leaves and hauled them to a mulch hole into which triturated the surplus water from the mill, which had been led in pipes from Kaluanui for the house and mill, to which he added whatever other waste material he could collect; and succeeded in preparing quite a pile of compost against the next season. To this he added the droppings from the cattle and sheep, collected from the fields.

After the soil had been plowed and cross-furrowed, and 
trenched by a mould-board, he spread the manure in the trenches immediately previous to planting. The seed of cane, so-called, is really a piece of the cane, and is a foot or more in length. Probably the best seed is the part nearest the ground, and like any other plants, vegetables or fruits, the best results are to be obtained from the best selected seed. The richness of the lower or butt end of the stalk in saccharine matter caused the planters to use the upper or valueless part. In the matter of seed he also knew that it is nature's law that seed from a distant field produced better cane than the replanting of a space with seed which had grown on the spot, and the attempt was made by him to import seed from Lahaina and elsewhere, and his theory proved correct.

Although much of the land on this estate was virgin soil, he knew that to make it produce to its highest capacity it was as necessary to fertilize the plant on it as it was in older cultivated lands. After the cane was up he supplied each hill with a fertilizer, a composition of apatite, guano and potash salts, although he did not fail to first correct and manure the soil.

At the stage when the cane is about six inches above ground such a fertilizer had a marvellous effect. It appears to compel the cane to grow. The great liar of Lahaina said "that he was unable to sleep at nights from the noise made by the crackling of the joints of the cane in its growth in the field adjoining his house."

Rats are a great enemy of the cane, and their gnawings cause much loss directly and indirectly on a large plantation. If the rat would confine its attention to a particular stalk until that was eaten and then attack others, the attention of the planter would not be so much diverted to him, but they do not so confine their attacks, and apparently nibble at several before the appetite is satisfied. "Kansas" felt that it paid to keep a Chinaman or two continually employed with a score of rat terriers, who reported daily to the bookkeeper, showing the tails of his captures each day. Cane thus rat-eaten does not fall as a rule, but continues to grow. One-half of the stalk would sour, from the admission of air where the rind or skin was broken and the other half be sweet. To correct this acidity at the mill required the use of lime, an over-use of which has the effect of preventing proper crystallization and of converting grape sugar into glucose. Cane soured by the borer is sim- 
ilar to that which is rat-eaten, and the expense of frequently stripping the older leaves at the base is very great.

Some planters argued that it were cheaper to stand the loss from the action of the borer than to pursue expensive stripping. Such a line of conduct can only result in giving the borer the opportunity to multiply immeasurably, and would not only be injurious to any particular plantation, but also to those in the vicinity. It is the same principle on which municipal governments demand of all inhabitants a cleanliness in their surroundings for sanitary reasons. The good agriculturist will not only keep his fields free from weeds, but will also persevere in his endeavors to exterminate such pests of insect or animal life as militate against the welfare of his crops for his own sake.

Different planters have varied opinions in regard to the details of cultivation of cane. One for instance, whose lands were under irrigation, insisted that it was unnecessary to plow the whole land and that to trench across the plain merely where the cane was to be planted was sufficient. He held that such procedure involved the use of less water, holding that disturbed soil would by capillary attraction absorb more water. He was unacquainted with the action of the air and its beneficent effect on plant life. The skin formed on lands, during non-use, largely prevents the circulation of the life-giving air to the rootlets, which aids much in causing the fermentation necessary for the production of plant-food found in the soil.

In studying animal economy it is discovered that the animal is merely different from the plant in that its rootlets (the villi of the intestines) are on the inside instead of outside. That the food masticated, digested, and converted into life-sustaining matter must by fermentation (which is life forming) be in a proper state for absorption, or such absorption by the villi will be abortive. Should the food which is taken into the animal system be mixed with certain chemicals, salicylic acid for instance, which is destructive to the animalculae produced during fermentation, no benefit will accrue to the animal.

The whole theory of life is that one life lives on another. In plant life it is similar, and the food to be properly digested or assimilated must be in the right stage. The action of air and water on soils has the peculiar tendency of promoting the very life-giving food upon which the plant depends. To contend, therefore, that the prevention of the undergronnd cir- 
culation of the air is as beneficial as the promotion of such circulation, betrays an ignorance unaccountable in the farmer of the nineteenth century.

Our agricultural colleges teach these matters, and farmers' sons on returning from school find their parents practicing them, although unable to give reasons for such methods, farther than "custom has shown it to be the most advantageous." Lazy, or pseudo-economical farmers, who know that nature's laws require that land must lie idle at least one year in seven, who fail to plow up such land prior to giving it the requisite rest, never realize the crops that the intelligent cultivator does.

Some fearful mistakes have been made by parvenu, or parties who have acquired large capital in other walks in life, who have gone into sugar culture and attempted to direct the cultivation their way. However, they received their lessons, and with burnt fingers have retired. There is probably no business wherein the losses occasioned by mistakes or ignorance are greater than that of sugar culture, and few agricultural pursuits which reward the educated farmer to the extent that it does. To know the nature of this grass, for it belongs to the grass family, the soil best adapted to the different varieties of it, to properly cultivate and nurse the soil by adding its complement, manure and fertilizer, and finally to preserve the whole juice of the plant in its crystallized form and then to obtain the highest market price for the product, might well engage the study of the thoughtful man. Every boor is not cut out for a planter, although many have made miserable attempts.

Probably in no part of the tropical world has so much scientific study been given to sugar as in the Hawaiian Islands, and the success attained has warranted the time and expense devoted to it. Cane grows well at all elevations below 2000 feet, but at the higher altitudes it takes longer to bring to maturity. The raising of sugar has been conducive to making landings on precipitous coasts where in former days it was not thought to be practicable to land, and therefore has done much toward developing the whole islands. 


\title{
CHAPTER XX
}

THE NEW MANAGER MAKES INNOVATIONS THAT STARTLE THE

\author{
"SILURIANS."
}

0

UR hero methodically and systematically arranged the gangs of men under the different lunas or overseers, each luna knowing the previous evening what his particular line of work was to be on the following day. By this system no time was lost. He also found it economical to carry the men on carts to the fields when working at a distance, rather than have them straggling along to the place of work, arriving more or less tired. He became acquainted with cach man in his employ, and they all knew that he was interested in them and their families. It paid in other ways than pecuniarily to be acquainted with them. His wife visited the quarters and encouraged the wives in many little ways in which a whole-hearted woman can well do, and they grew to love her. A little care in regard to the homes of the men returned fourfold the expense put out on them. Instead of the long series of rooms, separated by rough board partitions, where no privacy could be had and which could never be made to feel like home, there soon grew up little villages of cheap homes. Soon each of these cottages had its little garden, for which seed was freely provided. In after pages we will show a further improvement in these homes.

Fruits grow very freely in the tropics where any shelter can be obtained. The papaia, one of the most healthful of the tropical fruits, produces luxuriously, and within one year from planting the seed the gardener may expect a crop, and one which will be continuous for some years to come. When the fruit has reached its growth, and just before ripening, it makes one of the most wholesome vegetables. When ripe, its daily use contributes towards digestion, and is very much sought after by those who know its value. On the sheltered side of house or high stone walls it produces the best results. Chickens and pigs are very fond of it, and it is very fatten- 
ing to the latter, while its seed appears to cause the former to lay eggs abundantly. Its cultivation has been neglected, but on this plantation each laborer had a few trees in his little garden.

The Chinese are great consumers of vegetables, and were delighted at having a little patch of garden given them wherein they could raise their greens, melons, cucumbers, squash, etc. Without water it was difficult to do much, but they readily accustomed themselves to the climate and such as proved best were cultivated. There was nothing on the ranch that "Kansas" thought beneath him, and that he did not try to improve.

It had a fine herd of cattle, but like other places, the singular anomaly existed that milk and butter were scarce on the planter's table. He speedily rectified this, and in a few months his agents were selling Makawao butter at fifty cents a pound. Also, every family had a quart of milk delivered at its door. This was a small affair compared to the innumerable herd of hand-fed calves he was raising for work cattle and for beef. One of the treats to a visitor was to be taken to the milking paddock and see the breaking in of cows which had never been hand-milked, and the feeding of the calves. The natives made very good dairymen, and after being instructed by "Kansas" as to the manner in which he wished the stock to be cared for, were able to conduct this part of the estate without much direct supervision. When a cow was to be milked, she found it was useless to make any objections. The native would fasten her head securely and then, having pushed her up against a wall, he would thrust his head into her side, and then resistance was useless on her part. In two or three days the most obstreperous animal would submit willingly to be milked. The calves were kept in a field apart from their mothers, and when the cow was milked as much as was considered sufficient the milker would call the name of the calf, and to note how quickly "Pain-Killer," "Nigger," "Puakea," "Rose," or whatever its appellation was, would separate itself from the herd of calves and come to the gate, was surprising and instructive. The facility with which calves learned the names given them was always as much of a marvel as the ingenuity of the natives in naming them. These names stuck to them through life, and a tourist would be amused to note a team of three yoke of cattle denominated, perhaps "Abraham" and "Lincoln" and "Nigger" or "Puakea" and "Rose" and "Mo- 
lasses," until the combinations conld but arouse the risibilities of the observer.

Plowing by means of cattle was not to "Kansas's" liking, and he was the first on the islands to change the system to horse and mule work, firstly because the latter were so much easier fed, and secondly because the latter were so much more tractable and quicker in the work. Still all these changes took time, and eventually both cattle and horses were dispensed with, except in parts where it was most convenient to use horses.

He established a nursery shortly after taking charge, and from this was enabled to set out thousands of trees along the miles of stone fences. These soon began to attract attention, some old silurians predicting that he would bring the plantation to grief through the amount of money and time spent on tree-planting. The little church, the school house, the neat laborers' cottages, all kept well whitewashed, presented from a distance a beautiful picture against the green slope whereon the plantation was situated.

During his management he took the different overseers into his confidence, and in a nice way inculcated ideas in the matter of handling men. All the laborers were under contract and their work was compulsory to a degree, but he tried to eliminate any show of force and would have his officers lead rather than coerce them. This contract system had arisen under the laws regulating the whaling business, which were no doubt very applicable to the merchant marine, but "Kansas" felt that it was not quite the thing for agricultural service.

Theoretically it is right that men should fulfill their agreements when they go into them voluntarily, and civilly we compel men to do so under penalty of pecuniary loss or sometimes by injunctions of court. Still, there was in this system much that smacked of slavery, and gave critics of the system a handle for condemning the products of the islands on account of their being produced under it. Sometimes the "shipping" was not wholly volunteer and coercion was used to make men "ship" or renew their articles of agreement. And again the very character of the natives was such that they lived without any foresight, and when difficulties overtook them they did not hesitate to "ship" for a long term to get an advance to assist a relative or friend-and the individual was seldom benefited by the sum of money he obtained. 


\section{CHAPTER XXI}

TREATING OF THE ONE-TIME CONTRACT LABOR CONDITIONS ON THE SUGAR PLANTATIONS.

$T^{0}$

our hero the contract which he signed had been, as it was to many others, merely an imaginary line, as we speak of the equator, and which in no way interfered with his liberties. It did, however, bring him within the class dominated "contracted men," and amongst the free mechanics he was looked down upon; although "Kansas" had not felt the weight of his "contract" in any manner, farther than the possession of a feeling that he was legally bound and could not wriggle out from under it if he was so inclined. As a matter of fact it was to him, and to $95 /$ roo of the men, and women too, an imaginary line which bounded his liberties. To those who entered into the contract without compulsion, either moral or physical, it was no mental burden.

The native population, knowing they always had the dernier ressort of "shipping," as signing a contract was called, when they got into difficulties flew to the sugar planter for an "advance" to pay off some pressing debt, or the burial expenses of a relative or friend. This was the planter's opportunity, and he invariably secured himself by taking an acknowledged obligation that the party would agree to work a certain length of time at a definite rate. The majority of planters treated their men well, and seldom had occasion to quote to them the penalty prescribed by law in cases where there was a refusal to perform duty.

Planters, however, are human, and amongst them and their overseers there was a variety. Some parvenu would "ride at every opportunity," as the boys say, i. e., he would seldom miss the chance of nagging his men and telling them what he would do with them in case they were not on hand in the morning, or if the slightest lapse from the full quota of their duties was discernible. Planters frequently put men in as lunas, or overseers, who had been sailors, and of all the men to "ride," a man who 
has heen before the mast for years and whose head has daily been shampooed with a belaying pin in the hands of a brutal mate, such a one will take the prize.

The native is a good-natured, willing and apt laborer, and a man of a very forgiving or forgetting disposition. Rarely one is found who is revengeful or malicions. Constant nagging will even spoil such dispositions. Frequently on plantations, when a man was haled to court and inquiry made into the catsse of the desertion of labor, it developed that the perpetual "driving" of the luna had resulted in the man becoming uninterested in his work, and a temptation offering, he had failed to put in an appearance in the morning. In the first instance the judge would remand the culprit to his work, (costs payable by the delinquent). On a repetition of the offense the penalty would be a fine of five dollars, in either instance the culprit to be imprisoned until such times as he was willing to obey. In a third repetition the fine would be ten dollars.

A local resiclent could not contract for a longer term than five years, but a contract made abroad could be made for ten years, to date from the day of his arrival in the country. On the death of the employer, the contract was cancelled by operation of law, but this was avoided by the employer having a partner (real or fictitious), in which case the contract was not affected by the death. Many plantations kept stores, and, while making a profit on gomls iumished to laborers, manage! to keep them in debt, and at the end of one contract a man would be induced to "ship" again to get an advance to square the clebt. By this process the continuance $n$ f the contract would be interminable,

Frequently a native would contract to get the means to buy a horse, and the uncontrollable desire to possess a horse and gratify his desire for riding would entail many years of servitude. Planters, like the rest of humanity, were not all martinets, and generally speaking were kind to their men.

Occasionally a planter would forget himself so far as to expose his innate contemptible clisposition ly an act or language which brought obloquy on the whole contract system. One, for instance, who was enraged at a Norweigian contract laborer, for some infaction of dity, peremptorily orflerel him "to roll a large rock up a hill and chwn again" until it pleased the planter to order him to desist.

This exhibition of power over a man had a far-reaching infu- 
ence in bringing the whole system into disrepute. White men did not like to work on a plantation where they would be even suspected of being "shipped." Our hero knew that he was despised by men inferior to him in education, the only standard he would use in gauging men, and whose private lives were far from being such as should be held up as ideals for the young to follow. Probably had they known his intention in assuming the "yoke of servitude" they might have been more tolerant, but to him it had been a mere incident. He and his employer had been on sociable terms almost from his initiation, and he had often been consulted by him on matters pertaining to cultivation and to the best adapted form of agricultural implements.

"Slaves will talk," is an old Roman saying, and is as true in modern times. The different plantations were canvassed by the mechanics at the meal hours, and the rumors of their respective good or ill-management was discussed. Some of the men had worked on other plantations, and depicted the miserable quarters provicled for the laborers, some holding that the work cattle and mules had better quarters. The houses were mere shells, shelters from the sun, wind and rain, put up without the slightest regard for sanitation or privacy. Naturally, men could never be brought to look on them as homes or take an interest in improving their surroundings.

Our hero found that a slight outlay for cheap, pretty wall paper was much appreciated. That a little investment in climbing vine seeds soon spoke for itself in the manner in which outhouses were covered. Natives and Chinese alike vied with each other in making pretty arches and ornamentations for their verandas.

The native women, proverbially noted for their love of flowers, were easily induced to plant little parterres of phlox, carnations, crocus, tuberose, fuchsias, and others for which the elevation and climate were admirably adapted. He showed them many little tricks in gardening, and their appreciation of such interest in them was shown by their adapting tubs and cans of infinite variety as flower pots wherein little palms and vines garnished their homes within and without. Some natives who had been acquainted with the woods brought therefrom peculiar ferns and rare vines which had never been cultivated in the gardens of the rich.

To recite the numerous minor and greater improvements which he instituted would take more space than necessary. Many of 
them were subjects of comment by his neighbors, and the factors in Honolulu were kept duly posted of "infringenents" on what they considered the correct method of managing such an estate. The owner in the East was written to, and many times he was on the point of writing and insisting on a resumption of the former psendo-economical management, but his wife intervened and reminded him of his obligation to "Kansas" and of his perfect confidence in him when on Maui. As yet he had not assailed the mill, but he purposed putting in such lahor-saving machincry as would be up-to-date in economy as he considered necessary.

Finally he wrote the owner of his intentions, and the reasons therefor, and received a prompt reply "to touch nothing in the mill, as it pleased the owner to carry that as it had been." Now our hero felt that he had run against a stone wall, and he must wade through another grinding season and see at least a third of his crop go up the chimney or into the molasses drain, or be lost through lack of complete expressing. It was a very sad state of affairs, and he felt peculiarly handicapped as he could not, by the appliances they had, make a showing of what his ingenuity had done in the way of better cultivation, etc. He itched to be the owner and have unlimited capital to do with as his experience warranted. 


\section{CHAPTER XXII}

OUR HERO HAS A NAME AT LAST-AND AN OLD-TIME FRIEND AP-

PEARS IVITH ABUNDANT CAPITAL.

$\mathrm{T}^{\mathrm{H}}$

HE new manager retired to his office evening by evening and planned the work of this estate, and was gradually getting every part of it into producing as it should; and now he must stop building castles in the air and, metaphorically, put a ball and chain on his leg. A trip to Honolulu and a consultation with his agents availed him nothing. They had not approved of many of his improvements, and would not on their own responsibility follow him into new furnaces and machinery for the mill as well as an extra set of rollers. It was not the first time agents had set up their knowledge of the managementship of a plantation in opposition to the views of a practical man, to the ultimate loss of the plantation.

They had met the wrong man this time. When "Kansas" parted with the chief of the agency he remarked, "You will be sorry in the near future for not making the improvements I suggest." The agent answered, "We can afford to stand it." To which "Kansas" replied that they would admit their error when it was too late, as he was very much interested in the matter and his reputation was at stake.

If we go back a little to a period a few weeks earlier we will find the reason our hero had so much confidence in himself, and also of his ability to carry out any scheme he should project.

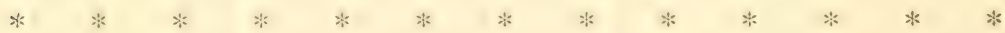

One evening, while he was dressing for dinner, the jingling of spurs was heard, and he judged that some travelers had stopped over for a meal and probably for a night's lodging. This was so common an occurrence that an extra chair was always placed at the table. The servants conducted the strangers to rooms, and when dinner was ready they were informed of the fact. Two gentlemen came into the dining room, one of whom proved to be the U. S. Geological Commissioner, the other a 
stranger. Our hero was delighted to meet the Commissioner and foresaw another evening or two of good company. The Captain had heard of our hero's changed circumstances while at Ulupalakua, and was not surprised. His companion was introduced, and they sat down to dinner.

The stranger looked intently at "Kansas" and his wife, and finally ejaculated, "Eab." The lady immediately arose, and walking around placed her hands on the stranger's shoulders, saying, "Charley Collins, I know you." Then a handshaking took place such as only long parted friends can appreciate. This was the friend they had followed to Grass Valley from Wichita, and he was overjoyed to meet them.

"What did you mean by saying 'Eab," " asked the Captain?

"That is merely the initials of his name," answered Collins. "He always called me 'Colly' and I dubbed him 'Eab.' His name is Ethan Allen Breed, and we thought there was too much of it."

"Are you any connection of the Breeds of Boston, of Breed's Hill?" asked the Captain.

"Yes, I have the honor of being descended from them, and from the family of Ethan Allen," answered our hero.

"My dear sir, if you had let it be known you were from Boston, and especially a descendant of Revolutionary sires, the Americans of Honolulu would have worshipped you as the natives did Captain Cook," said the Commissioner.

"But he is not that kind of a Breed," remarked Collins; "and when you know him as well as I do you will find that he depends on his own head and hands, and not on any accidental ancestry."

The story of the acquaintance between Collins and Breed (for our hero now has a name) was soon told. They were schoolmates and grew up together on neighboring farms. Both had courted the same girl, and Breed won her. Their friendship continued, and they moved west together and battled for the right in Kansas. Collins, having no home, had caught the California fever; and this was their first meeting since the Kansas days. After dinner came the pleasant chit-chat on the veranda until Mrs. Breed took the children to bed, when they retired to the office. Here Breed ran over his experience and anticipations, and the gonlogist gave considerable arlvice which was eagerly absorbed by Breed.

After the Captain had retired, Collins told of his ups and downs. He had mined in all the different parts of California, 
Mexico, Colorado and Arizona, in which latter place he had met the Commissioner. He had made and sunk fortunes, and had discovered that there was more gold to be made in "milking the market" in San Francisco than in any mining operation; and in teaching the "mud hens" to lay golden eggs in the stock exchange there was more profitable amusement than in putting up grub stakes for miners or prospectors. He had amassed a large fortune and still felt a thrill of pleasure in adding to it. His chair in the Stock Exchange brought him a very fair income, and he was director in various companies, many of which brought him more than $100 \%$ per annum. He had not married, as he had led a nomadic life, and now that he had acquired more than a competency had no inclination that way, partly because those whom he would have would not have him, and those who sought him he would not have. He had long desired to visit the $\mathrm{Ha}$ waiian Islands, and knowing his friend, the Commissioner, was here, he tore himself away from his business for a pleasure trip. He was overjoyed to meet his old-time friends, and remarked to Breed that if he had any schemes in which capital could be invested that he would furnish it to any reasonable amount.

"Eab," said he, "you were always a schemer from away back, and if the lines had fallen on you in pleasant places you would have been a millionaire many times over; are you not even now planning some great scheme?"

"Well, Charley," answered Breed, "no one of brains can climb to the village of Makawao and look abroad on this grand vista and not allow his imagination to run riot with the possibilities of the great expansion of sugar culture which capital could effect. I have dreamed of it, and figured it out on paper, and can lay before you such a plan that if put in operation will lay in the shade the production of any gold mine in California, and the best of it is that the returns will be interminable and it is honest. No heart aches come from the possession of wealth acquired from the cultivation of the soil, as must come to a sensitive mind who has profited by the 'salting of a mine,' 'furnishing untrue reports of the prospects,' and thereby causing widows and orphans to invest their whole to their certain loss, etc. Even booming townsites as was done in Kansas was a very questionable manner of making profits."

"Eab," said Collins, "I always knew what you were thinking of, for you had imbibed from your mother the fundamental prin- 
ciple of honesty. When we carried guns together in Kansas I felt that you were the kind of man to tie to. Tell me your scheme, Lab, and I will furnish the money, should it require $\$ 10$,০০০,০০০."

Breed then produced the maps of the estate of which he was manager, and also a large one of the whole island. "Now Charley," said he, "if I had control of $\$ 10,000,000$ I would buy up the plantations of Haiku, Hamakua-poko, I'aia, Grove Ranch, East Maui, Wailıce, Wailuku, and WVaikapu, giving the owners their own prices. The whole plains below here can be leased for a very long term at a low rental, as it is and has been nonproductive. I would thus have control of all the surplus water of both ranges of mountains. In two years I can have 40,000 acres of land in cane, and I will guarantee to produce three tons per acre at a cost not to exceed thirty dollars per ton. This will amount to $\mathrm{I} 2 \mathrm{O}, 000$ tons of sugar, on which we can safely estimate a profit of five and one-half cents per pound, or \$I3,000,000. Granted that prices may fall from seven cents per pound, is there not still a very large profit?

"It is costing now seventy-five dollars per ton to produce sugar, but eventually I will produce it for thirty dollars. At present No. I sugar is selling at eleven cents per pound, but the crop does not average over seven cents. I have still left an enormous margin of which I have not spoken, viz: that I know I can make these lands yield from four to six tons per acre. The management, under one head, will be true economy, and the ownership of the entire water system will ensure good crops."

Collins followed his friend through the proposed details of the division of labor, planting, fertilizing, irrigating, manufacturing, shipping and marketing.

"Yes, Eab," said he, "I knew that Yankee brain of yours could not be idle, and with the exception that you may have over-estimated the number of acres you could get into cane in the given time, I believe you. Why, Eab, with such a Machiavellian scheme as that I could float a joint-stock company and milk the market not only of San Francisco, but of Wall Street."

"There you go again, Charley," said Breed, "always scheming to get the better of the masses of unsophisticated people who haunt your stock market. If you will not abet my plan of bringing wealth from the soil, and furnishing living for thousands of 
employees and their families, please forget the scheme I have unfolded."

Collins now remarks, "Eab, if you were not the man you are I should put you down as a lunatic, but knowing you as I do, I will give you credit for being an honest man. I will form a jointstock company, and, relying on you, shall depend on the profits from the cultivation of the soil. I will carry more than one-half of the stock, so that I can ensure you the managementship and will aid the enterprise in every way possible."

The morning star was shining brightly when these two schemers retired. Visions of untold wealth floated before one, whereas the immensity of the labor to be undertaken did not drive sleep from the eyes of the other.

The assurances of his friend made Breed somewhat independent in his dealings with the agents, and in after chapters will be unfolded the extent to which this scheme was put into operation. 


\section{CHAPTER XXIII}

MADAMT TAKES A NATIVE MIAIDEN INTO HER HOUSEHOLD, AND

HAS AN INTERESTING CHARACTER STUDY.

T

T would be wrong to omit somewhat of the part which Mrs. Breed took in the home-life, as a good woman is not entirely lost in the life of her husband. When they first came to the plantation Mary, the old parson's daughter, had volunteered to bring a servant girl whom she could recommend. The next day she brought a bright, healthy girl of pure Hawaiian stock, one of the original and unsophisticated country girls. She was about ten years of age and was as large as an Eastern maiden of fifteen. She had all the awkwardness and apparent bashfulness of the rustic, but Kamaka's history would make a most interesting chapter. She had beautiful limpid brown eyes, a head of hair that was a dream, in that from its fineness and luxuriance it would be the envy of many an Eastern belle. She wore a mammoth native-made hat, on which, according to Hawaiian custom, was a wreath made fresh that morning from the beautiful ohia blossoms, of a shade between pink and red, probably magenta. Her dress consisted of a holoku, nearly like a "Mother Hubbard," made of two shades of pink and trimmed with blue. The tout enscmble, from the crown of her head to the soles of her feet, which unfortunately were marred by Eastern shoes three sizes too large, produced the most charming impression, and captivated Mrs. Breed immediately. Her name was Kamakauilani, but Mary said it was customary to call her Kamaka, that being a favorite name for a child which from its intelligent face gave promise of a bright future. Kamaka could ride horseback like a rough rider, and conld hitch up the team and drive through the plantation roads and those of the surrounding country as well as the most experienced postillion.

Mary said she had been accustomed, like the rest of the natives, to horses from the time she was tall enough to grasp the mane, and by placing her right foot against the horse's knee to 
spring up and hook her left foot over the animal's back. Once seated, with or without saddle, no horse could throw her off. She always rode astride, catching the iron stirrup between the great and next toes, and with the peculiar riding dress of the natives made a most handsome appearance as she dashed at full speed across the plain or up or down the country roads. Kamaka soon shed her shoes and learned her duties in the household, and became really one of the family. Like the rest of the natives she was very free in her ways, and soon knew every bullock and mule driver on the plantation, many of whom remembered her sweet tooth and threw her pieces of cane in passing. At times Madam would attempt to check her in her freedom, but she could not be made to comprehend that to swing on the gate and swap badinage with the plantation hands was unbecoming. A child of nature she was, and like all the natives, could not brook being confined to foreign manners and deportment. She apparently had many parents, as on being asked who this or that person was she would reply that it was her father or her mother, as the case might be. All the brothers and cousins of a man in Hawaii are parents to his children, and also all the brothers, cousins and sisters of a woman are parents of her children. So also all of their children would be denominated either brothers or younger or older sisters.

Evidently Kamaka was a great favorite with her people, as it was rarely that any of them, coming out of the wooded country and passing the plantation, failed to bring her a wreath or lei of flowers, or of the fragrant glossy leaves of the maile vine, or perhaps of the golden fruit of the hala. This last, while not hav. ing a pleasing smell to foreigners, made a beautiful and becoming wreath when worn on the bronze skin of the native.

She spoke English very nicely, and her vocabulary steadily increased from her association with Americans. She was very fond of the children, who soon learned to love her and confide in her their many little secrets. As she proceeded about her duties she sang her sweet native airs, of which she seemed to have a large repertoire. All Hawaiians are exceedingly fond of music, either vocal or instrumental, and learn very quickly anything that strikes their fancy. Madam, being a good pianist, was pleased to give Kamaka some instruction, for which she was amply repaid in the rapid proficiency of her pupil. After she had acquired command of the instrument she readily played accompaniments 
to her native airs, and visitors at the plantation were often afforded the treat of hearing in the parlor songs they had heard on the streets of Honolulu, or from sailors or guides around the islands. Not only was she good and entertaining company for the family, but she had many little accomplishments, the practice of which made her a useful member of the household. She could make fans from grasses or leaves of the lauhala or palm; mats fine or coarse from the lauhala, for the floor or table; hats from a variety of materials, and also feather kahili ornaments. Also at making toothsome native dishes she was an adept. Some of these will be described in a future chapter. 


\section{CHAPTER XXIV}

MADAM INTERESTS HERSELF IN THE NATIVES, AND LEARNS MANY OF THEIR PECULIARITIES.

$\mathrm{M}$

ADAM visited the native quarters frequently, taking $\mathrm{Ka}$ maka along as interpreter, and was the means of ameliorating the condition of many women and children. She was acquainted with remedies for simple troubles of women and children, and distributed medicine amongst them as required. She also instructed them in sewing and making garments, and encouraged them in the manufacture of every description of goods from the products of the country.

She was surprised at the indomitable perseverance of the women in working up beautiful patterns from hard vari-colored seeds of trees and shrubs. Also at the great patience displayed by them in weaving or plaiting hats and mats from leaves of palms and grasses, and the ingenuity displayed in weaving therein colored patterns made from stems of maiden-hair ferns or other colored material. Many of them were quite apt seamstresses, and all seemed pleased at the Madam's interest in them and thein work, showing their appreciation of her by adopting her suggestions in making trimming for their dresses and admiring the styles or modes invented by her. Also when she suggested that by uniting their efforts they could work somewhat effectively in causing a social reform in the morals of the community, they cuickly followed her and got up huis or societies wherein this or that class of work could be undertaken with great promise of success.

The native women had much force with their husbands politically, and with few exceptions the men were guided by their wives' advice in voting for candidates for the local legislature. So that really Madam was a power in the little community to a greater extent than she had any conception of. Kamaka proved to be the connecting link between the manager and the native people. 
Breed told in after years of the number of her fathers he had assisted in burying, and their names were legion. Then occasionally a mother or father would be captured and deported for the crime of having leprosy. Sometimes a parent or two would be arrested for manufacturing "okolehao," a spirit made from the fermented syrup obtained by crushing the cooked ti-root. Now and then one of her parents would be in pilikia from lifting cattle, or subscribing some planter's name to the foot of a draft on the agents, or some other of the numerous ways foreigners have invented of getting the unsophisticated native into trouble.

Poor Kamaka took all their cares into her own bosom and wept and sympathized with all who were in distress, expatiating most earnestly to her mistress on the naughtiness of some one in being the means of getting her parent into pilikia.

At times a wail would be heard from the back yard, and Madam knew that she would soon hear of another death in Kamaka's family. It is the custom amongst this people that when relatives meet after a death has occurred in the family, that a wail shall be made. So at times a crying could be heard before the rider came in sight, and Kamaka knew that another mother or father had gone to her or his last bourne, and would rush out prepared to make the obligation to the approaching mourner. These sorrows, however, did not appear to make a lasting impression, as Kamaka would soon be found building block houses with the children or throwing bouquets to passing bullock drivers, at which she appeared to excel, or with a face as joyous as a summen day hitching up the fractious horses to take the children for a drive. The world to Kamaka was like the surface of a fish pond, usually placid, but occasionally disturbed by a ripple caused by some extrancous cause. Possessing an exuberance of health, without a care for tomorrow, she was truly happy and her happiness was contagious. None but a bilious disposition could fail to be enlivened by her pleasant face and jocular sayings and actions. 


\section{CHAPTER XXV}

THE HAPPY MARRIAGE OF KAMAKA IS FOLLOWED BY, ALAS, A TOO FREQUENT SEQUEL-PIQUANCY OF NATIVE COOKING.

A AVING introduced Kamaka, who proved so much of a connecting link between Breed and his family and the native population, it would be interesting to tell more of her, as it affords an opportunity to further study the manners and customs of the natives.

During the years that had passed Kamaka had blossomed into a very fine young lady. Her manners, in the presence of foreigners, were as refined as should be expected from her continuous association with Mrs. Breed. She had been sought in marriage by several of the natives, and her father had engaged her in more than one instance to persons who were very eligible partis, but Kamaka scorned them.

Finally she accepted the proposal of the plantation carpenter, and a great marriage feast was prepared to which all her kindred were invited. Of course, being the belle of the neighborhood and having so large a connection amongst the natives, this feast or luau must be the greatest event that had yet taken place on Maui. A great lanai, or shelter, was erected by her friends, the sides and roof of which was made from thatched cane leaves, and within this the feast was to be held. From far and near relatives and friends came, bringing their hookupu, as presents to a chief or great personage are called. Native manufacturers of kapa, kou calabashes, Niihau mats, feather kahilis, emblems from ancient times in the form of idols in wood, feather and stone, in fact everything mentionable dear to the heart of the Hawaiian was brought as tributes to the love of the people for Kamakauilani.

Horses, cattle, turkeys, chickens, pigs, fish, limu or sea-weed, kukui-nuts, cocoanuts, fish-nets, etc., etc., were driven or carried to the plantation house as wedding presents. Three bullocks, twenty hogs or pigs, innumerable fish, and fowl, and last, but not 
least, three $\log$ were slaughtered to furnish food for the multitude.

The quantity of poi, sweet potatoes, cocoanuts, kukui-nuts, limu, and raw fish which was prepared cannot be reckoned.

The making of native puddings from taro and cocoanut, sweet potatoes and cocoanut, and arrow root and cocoanut, kept many native stewards busy for some days. Several imus or native baking ovens were occupicd in cooking the assorted beef, pork, fowl and fish.

The manner of native cooking is most interesting, and it has frequently been asserted by epicures that food prepared in Hawaiian fashion has a piquancy about it that is very satisfying.

A large hole is dug into which wood is piled and covered with stones. The bullock, hog or fowl having been cut up into pieces to which salt is added, is wrapped in bundles in ti-leaves. After the fire has burned out the hot stones are leveled off and quickly covered with banana leaves and all these bundles piled up into a pyramid and the whole covered with leaves and finally heavily topped with sods and is allowed to stand for several hours.

On opening such an oven the different food-stuffs are usually found to be thoroughly and appetizingly cooked.

Mention must not be forgotten of the luau or taro leaves, from which the feast takes its name. These are done up in bundles and either wrapped with the beef, pork, etc., or cooked in separate packages. This is one of the most delicious and succulent of "greens."

It is said that large quantities of "okolehao" found its way (unknown to the planter) to the vicinity of where the feast was to take place.

The poi for the feast was served in home-made bowls or containers which are fashioned most ingeniously and quickly by the expert natives. They take a five-pound lard tin and fold over it ti-leaves, around which a cord of woven leaf is fastened. Then by folding back the ends of the leaves and wrapping the woven ferms around it, and slipping the whole off the mold, a cleanly cheap bowl is provided. Our reader will note that no washing of dishes would follow a native luau, as it was merely necessary to throw the lot of bowls away and they are quickly eaten by cattle or hogs.

The natives dearly love a luau, and the story of its arrangements and success or failure constitute the theme of conversa- 
tion in many homes in the vicinity for a long time, or until it is eclipsed by a greater affair of the kind.

The parlors of the planter's house were thrown open for the occasion, and Kamaka, dressed in white with a beautiful wreath of natural orange blossoms interwoven with the dark glossy leaves of the fragrant maile, attended by a bevy of native girls similarly dressed, marched up to the old parson at the end of the room where she was met by the brave carpenter. The marriage service in English was gone through, and innumerable friends came forward to congratulate the handsome couple. Felicitations being over, the bridal pair led the way to the lanai, where the feast was spread. Hundreds of guests sat down on the rushes which covered the ground, men and women alternately around the immense spread.

As they came from the wedding each guest was decorated with a wreath of flowers and maile, and the whole made a very beautiful scene. At each plate, or rather place, for leaves of the ti were used in lieu of plates and banana leaves in lieu of table damask, the stewards had placed bundles each of fish, fowl and flesh, as well as a green bowl of poi together with clam shells filled with inamona.

After the feast, which was accompanied with music from a company of trained singers, all departed to their homes, the majority carrying away bundles of the excess of foodstuffs. In a hundred homes the wedding and the feast was talked of for many days. Kamaka's beauty, and how fortunate that white man was to get such a delicious ripe fruit (hua pala); how much I ate and drank, the songs that had been composed in her honor, were the comment of every guest.

After Kamaka had been married three months she told her husband, one day, that she was going to see her mother. She failed to come back that evening, and the following dav he went to look for her. Her people said that she had been there and had gone off with one of the bullock drivers from the plantation who had met her there.

In a few days it was discovered that she had fled to Hana in company with this paramour, who had "shipped" on the Hana plantation, forgetting the debt he owed to our hero. To "ship" doubly was a serious offense, and it was considered necessary to make examples of such offenders, so a policeman was sent after him. He had expected to be hunted up, and when the 
policeman put in an appearance, of which he was duly warned, he and Kamaka fled to the fastnesses of the mountains, where search would be difficult and probably dangerous.

The carpenter made no effort to pursue her, but his life was broken up and he took to drink and was discharged.

Kamaka and her lover got away to Honolulu, where in a few months he shipped as a sailor on a whaleship and was heard of no more. She with her little half-white son was a figure on the streets for some years, and finally perished in an epidemic of smallpox. On account of her education and accomplishments she was the belle of her class, and many stories are told of the wrecks she left behind her in the metropolis. She retained her beauty and innocent expression of features and charming manners until the last. 


\section{CHAPTER XXVI}

MRS. BREED LEARNS HOW TO PREPARE AND PRESERVE THE MANY

DELICIOUS NATIVE FRUITS.

$\mathrm{M}^{\mathrm{R}}$ RS. Breed found that housekeeping on the islands was a much more difficult proposition than in the East and in California. To add to the cares, it was necessary to entertain much company, as there were no hotels to which a stranger could go, and it had been the custom all over the islands to receive any tourists or travelers who might come along. She had been brought up in all the little arts which make towards the comfort of home, but it was not possible to do with her own hands as she had been accustomed. The climate was somewhat trying, and with her growing family and the multiplicity of visitors she found her time taxed to the uttermost. It frequently happened that every bed in the house would be required, and the table had its quota filled. With a good supply of eggs, butter and milk, and a well filled pantry of canned goods, it merely required a little more work on her part to enable her to set such a table as she liked. Sometimes it was felt burdensome to entertain strangers whom there was no likelihood of ever meeting again, and who left without apparently being grateful for the hospitality extended. Then again "angels in disguise" were met, the pleasure of whose acquaintance amply repaid her for any extra trouble.

In the East she had learned the culinary accomplishments of making jellies, drying fruits, and making preserves, as well as of canning fruits; and in Hawaii, as far as she was able, she added to her stores any island fruits which she thought would be nice to have between seasons.

She found that mango sauce, made from mangoes which had attained full size, was equally as nice as green apple sauce. Also the mangoes when cut up and dried were much preferable to dried apples for pies.

She always kept a few jars of tamarinds, laid down in layers of sugar, which made a pleasant, subacid and wholesome drink. 
From the mountain the natives brought her ohelos, akalas, and pohas in season, and she soon learned to treat them in such manner that they were very palatable. Ohelos ( $r$. reticulatum) are extremely abundant at the higher altitudes of Haleakala. They are insipid of themselves, but, when combined with sugar and a little juice of lemons made a very agreeable addition to the dessert. The akala ( $R$. Macraei) grows to an immense size in the ravines on the mountain. It is a reddish purple raspberry which is, unprepared, of an unpleasant bitter taste. When allowed to stand over night in sugar the bitter principle is eliminated and it makes a most delicious short-cake, preferred by many to strawberry. Some of the akala are an inch and one-half in diameter.

The best of all the island fruits is probably the poha (Cape gooseberry). It makes a very piquant stew, and for making jam or jelly cannot be excelled. It has a peculiar flavor which cannot be described, but one which the stranger soon becomes very fond of.

The large purple figs of Makawao, to be most enjoyed should be eaten direct from the tree, as when fully ripe they are a lobe of pure jelly. When peeled and cut up with cream and sugar they make a most luscious dish.

Guavas, of several varieties, were very plentiful along the hedges and covering the whole stretch of the mountain side. A lemon guava made an excellent jelly, but the large Hawaiian red guava when either stewed or sliced made a very appetizing adjunct to the dinner table.

A fruit called hualilikoi, a passion fruit, the vines of which covered old fences like a pall, when served as a custard, barring the cooking, was also much appreciated.

The banana is, however, par excellence the staple dish of the islands, and Madam had a great varicty of ways of preparing it. Always bunches hung on the verandas for every one to help themselves to, but when cut up and served with cream and sugar they were preferred by many to strawberries. Fried in butter, or made into fritters, or boiled in water, or baked in their jackets or dried and made into a fragrant sweet flour which can be used for many purposes, the banana is the saviour of the housekeeper. Bananas and oranges thinly sliced and in alternate layers with sugar, and well cooled before serving, was described by many as simply delicious. 
Mrs. Breed found that making hash from a mixture of fruit with the addition of juice of lemon was also a way of pleasing the palate.

In making marmalade and using ripe papaia as stock she invented something as good as apple-butter made at home. Papaia, itself, when fully ripe and just off the tree, served with snow or ice, also was delicious and made a gratifying breakfast dish.

She early learned to select and cook breadfruit in a manner that made it possible to use it either as a vegetable or as a dessert. It certainly was a toothsome pudding when prepared for that purpose, i. e., when fully soft-ripe and cooked with a lump of butter injected in the part from which the stem had been extracted. When cooked before reaching the soft-ripe stage it made a vegetable not to be despised.

Madam had eaten inamona, roast kukui-nut crushed with salt and pepper, and felt certain from its richness that it would be a condiment that would please an epicure, and tried her hand at making it in different ways. After roasting the nut and discarding the shell she crushed the kernel into a paste and added salt and a taste of red pepper in the natural state. This made a healthful and appetizing condiment and her recipe for its manufacture was sought by many of the island ladies. Her husband remarked to her on one occasion that with advertising sufficient and putting it up in marketable form she might make a fortune. It is also very nice when the kernel is merely broken into grains and eaten dry with baked fish or pig.

In her preparation of chutney was probably where Madam excelled. There are many kinds of mangoes on the islands, all of which have been imported. One especially is denominated the chutney mango on account of its freedom from the stringyness common to most of them. Like anything else in this life, if we would have anything good we must put labor and value in it. So to prepare chutney, as we find it best from India, we must have mangoes, orange peel, spices, and vanilla, and raisins, as well as the knowledge of the proportions of each necessary for success.

The Chinese cook whom Madam found on the plantation, and who had been so long there that he was considered a fixture, was decidedly averse to any innovations in his manner of cooking, and resented any interference in his kitchen. He soon found 
that Mrs. Breed was going to control her household and grarlually learned from her many little improvements in preparing dishes. He called her "Mamma" and was as much interested in the housekeeping as she herself. He would keep her informed of what was to be had in the way of fruits, and would saddle a horse and ride for miles to procure a roaster, or to order fruits from those who were accustomed to collect such on the mountain.

The cook had learned the art of making delicious cakes from taro, both fried and baked, and kept up the reputation of the ranch as a place where a traveller was sure of a good meal. Some of those good old Chinese cooks can be compared favorably with many of the old mammys of the South.

While we are not writing a cook-book, nor compiling a lot of recipes for the preparation of Hawaiian dishes, yet we feel that it would be interesting to many readers to show somewhat the part which the lady of the house took in aiding her husband and making life in the tropics more pleasant. 


\section{CHAPTER XXVII}

MADAM EMBELLISHES HER HOME WITH NATIVE CURIOS THAT ATTRACT THE CHARMED ATTENTION OF VISITORS.

I N the embellishing of her house with curios collected throughout the islands, giving it a unique appearance as compared with homes in other lands, Madam was indefatigable in her pursuit of every thing Hawaiian. Some of her chairs, for instance, were covered with lauhala leaves woven in such manner as to cover the backs, rounds and legs, and were quite odd. A cane tete-a-tete similarly covered, whercin the stripes were made of flattened maiden-hair fern stalks, as it stood in the middle of the parlor, attracted the attention of the stranger, and was favorably commented upon. The pictures of island scenery which embellisherl all the rooms, together with the large collection of copies of island fruits and flowers which adorned her diningroom, were as beautiful as pictures of foreign scenes; and it was a patronizing of home industry which encouraged the local artists.

In another chapter we will tell of the education of her children, which absorbed so much solicitude on the part of Breed and his wife, the supervision of which naturally fell to the mother.

In working with the women, Mrs. Breed knew that the only way she could make her efforts effective was to provide employment for them. Prayer meetings and temperance meetings for discussion of methods for ameliorating the condition of certain families and individuals were well and had a certain effect in making the women feel that they were influential members of society, but in the tropics where idleness was a condition, she knew that there must be some incentive for profitable employment. Some of them worked in the fields and were under contract the same as the men, although this had to be with the consent of the husband, but these were looked down upon by their free sisters.

Of the ingenuity and application of the women in making 
many articles from the seeds, grasses, palms, and fibers, she knew, and endeavored to direct their industry into lucrative channels. She offered to make a market for all the articles they could manufacture, and induced many of them to braid cane stalk into hat braid which readily found a market among the straw hat manufacturers of the East. Also braid from the loulu palm and lauhala, which they made so prettily by blending these with natural colored fern stalks properly ironed out. From the squash vine they made an exceedingly light and handsome braid applicable to the manufacture of ladies' hats. Also they made artificial flowers from the same, and were quite adept at using aniline dyes for coloring.

From a fine rush or grass some of them made hats which were tough and strong and resembled the Panama of commerce. Others again made a variety of articles from the hard and brilliant seeds of the koa, nawiliwili. and other trees.

From the fiber of the olona others twisted fishline, which found a ready market in Honolulu for both fish-nets and line. All of these were from native growth, but many of the women became quite adept at machine and hand-sewing and made up the cotton garments of both sexes for store orders and for family use. Many of them made patchwork quilts of unique designs, inventing their own patterns from leaves of ferns or bread-fruit or other trees. Still others worked incessantly at crochetting and tatting, and made very pretty designs which readily sold in town. They kept their children's clothes well washed and ironed, if they were made of cheap material, and were very particular to have them punctual at school.

They were always pleased to have madam visit their homes, and it is surprising to note the improvements which took place, noticed principally in the little embellishments which adorned the walls. All the native women called her their aikane (friend), and while not bold or impertinent, did not appear shame-faced in her presence, and she always showed that respect for them which they merited.

How much even one good woman can do by giving countenance to her fellow-women! How they will rise to the occasion, if we may use the expression. To preach to them only, had the effect of making hypocrites of them, as they were as apt as other people in presenting their best side to the preacher; but to recognize them and visit them in a friendly way brought out all that was best in them. 
Mrs. Breed was perhaps peculiar, for she had the happy faculty of remembering names and could ask a native mother how Keoni, Pulehu or Maila was, and how they were getting on at school. She also had learned considerable of the language and gradually acquired more of it; certainly she could talk enough to please them, and the natives are naturally too polite to laugh at a foreigner who makes errors in attempting to speak their language. They knew they had her sympathy in their afflictions, which went further than anything else, and there is nothing they would not do or promise to do for her if they thought it would please her. 


\section{CHAPTER XXVIII}

THE ONCE OBSCURE "KANSAS" BECOMES OWNER AND MANAGER OF AN IMMENSE SUGAR ESTATE.

$\mathrm{B}^{\mathrm{r}}$ REED wrote the owner in the East, offering him for his plantation a sum of money, which if invested at 5 per cent., would realize annually as much as the receipts of the plantation had been during the last year of the owner's management. Acting on the advice of friends, the owner accepted the proposal. Breed now proceeded to purchase Haiku, Hamakuapoko, Paia, East Maui, and Waihee, Wailuku, and IVaikapu Plantations, giving the owners their own prices for them. Some of them willingly took stock in the new company in part payment.

A line of steamers was placed on the route between San Francisco and Kahului, touching at Honolulu. Immense quantities of machinery and pipe were landed and hundreds of men employed in ditching between the valleys on the Koolau side of Haleakala, the valleys being crossed by immense wrought iron pipes which were true siphons.

A permanent railroad was laid to Waihee and to Waikapu connecting at Wailuku, from whence the cane was carried to a mill above Kahului. Another permanent line connected the other plantations. From these portable lines were laid into the fields, and it was thus possible to dispense with hundreds of mules and cattle and drivers heretofore used.

A large mill was built above the site of the old one, to which all the cane accessible thereto was havled.

He acquired a long lease of the Wailuku plains and converted the thousands of acres there into cane-producing lands.

Without depriving the taro lands of water, he had a sufficiency to supply more than sixty thousand acres. Having run his water ditches in Koolau at a good elevation he was enabled to throw the lands near Kalepolepo under cultivation, and at the same time save what had been wasted in all the valleys in that country by percolation. He built a few reservoirs where the contour of the land made it safe and cheap to do so, and the life-giving fluid 
flowed where it had never before, except as rain. Gradually he substituted steam plows for mules and cattle wherever possible, and these did better work both at subsoiling and cross-plowing than it was the custom.

Breed assumed the management of the whole estate, keeping four sub-managers. From the overseers on the different plantations he selected the best, retaining only men who had the reputation of living moral lives and whose industry and sobriety could be depended ipon.

The natives flocked to him from all parts of the islands on account of the kind treatment they received. They are much like children in their dispositions, and thrive best when under a chief or one who will manage for them. Still he was obliged to bring large numbers of Chinese, as laborers became scarcer. Towards this end he sent one of his managers to China with instructions to select healthy men from the rural districts and as far as possible to obtain those who had wives and families.

Homes were provided for each of these, with a reservation for a small garden where each might raise his modicum of vegetables. In building these homes he adopted a method long in vogue in the south of France and in Italy, of building from material on the ground, which was much cheaper than from imported lumber. By using the soil combined with a certain amount of small stone or gravel and using molds, he built such solid structures as would last for centuries, and yet had a very pleasing appearance from a distance, and were much more comfortable and homelike than the long rows of shanties formerly used. As these were crected in little villages and some of the cottages two stories in height, they reminded one of similar villages in Europe.

The common laborers dirl all the work of making these houses excepting the fittings of doors and windows and roofing. They cost but little more, if any, than the burlesques formerly called makahiki houses, or laborers' quarters.

By a libera! policy of paying fair salaries to his managers, overscers and laborers, and taking an active interest in their welfare, he was enabled to obtain not only the best muscle, but the best brain work, and this great estate was never, in a manner, dependent on the life of one man. He allowed nothing to go to waste and made all parts productive, importing as little as possible of what could be raised on the estate.

On the upper lands he produced all the wheat and oats neces- 
sary for hay and grain for his animals. Work cattle he discarded entirely, and the number of horses and mules used for plowing corners and small fields where the steam plows could not do effective work was very much reduced.

In every way that ingenuity could be applied to the planting, cultivation, and manufacture of sugar he led the way, and the estate was visited by sugar planters from many parts of the world.

One part of the estate was invariably visited by all, and as it was Breed's own idea, well carried out, it is worth mentioning. He had frequently noticed the greenness of the grass in a small canyon and observed that the verdure there lasted much longer than on neighboring lands. He surmised that it was caused by an underground seepage from the mountain. Acting on this presumption, he excavated a tunnel into the side of a ravine above and was repaid in securing quite a flow of water. He prosecuted the work at some expense of labor and powder and was amply rewarded.

He then erected a dam in the ravine below, having first built a very large cistern, to preserve the overflow. This seepage, thus conserved, was ample to supply the mill and all the houses of the manager and men in the vicinity, and afforded enough for the little gardens. Probably this little invention of his made him more talked of than any other.

It had long been known that the water stood in cavities in the rocks for some time after other sources were dried up, and wild cattle frequently resorted there. Native cattlemen had been accustomed to expect to find water in that place, a point which he had learned from some of his people, and he had merely followed a course which he had frequently seen pursued in California. In a dry land, or one which is dependent on the periodical rainfall, water in pipes is a convenience greatly appre-
ciated. 


\section{CHAPTER XXIX}

CAPITAL AND LABOR AS YOKE FELLOWS-A CO-OPERATIVE SCHEME THAT WORKED-CHRIST QUOTED.

$\mathrm{M}$ ANY incidents could be told of Breed's thoughtfulness in making provision for his men and their families, and as the years rolled around many of those men felt that the houses they had so long occupied and around which small orchards and gardens had grown up were their homes. This was precisely the home feeling he had sought to inculcate amongst his people, and it is pleasant to be able to say that the Hawaiians were not the only nationality who appreciated them. Quite a number of the Chinese had returned to China, but after a year or so had come back to his employ, bringing their wives and little families.

Also many of the white men who worked on the plantation considered it their home, and knew they would be certain of promotion or of having their salaries increased if their industry, sobriety and interest warranted such reward. With new maclinery and railroads, portable and permanent, and the locomotives and steam-plows, there came a large increase in the foreign population on the estate-and this brought its concomitant social functions. Schools, social halls, public reading rooms, and other public institutions sprung up which were arranged for by the ladies and gentlemen who lived on the extended parts of the estate. It did not appear that "to live was all of life," as had been the custom and is still unfortunately the custom on so many plantations.

To encourage thrift amongst the employees they were allowed interest on such moneys as were to their credit, and it would surprise any who have not taken an interest in such matters to note to what an extent the common laborers as well as the better paid men took advantage of this arrangement, and what a large sum it left with the estate.

Breed, while recognizing the enormous profits in sugar culture, felt that it was largely due to the laborer, and began to realize that they were not paid in proportion to the service 
rendered. While the invested capital assumed risks, and the brains of the managers were entitled to the lion's share of the profits, it was apparent that the common laborer was underpaid. He could not remedy this by paying more, as this would materially affect the labor market throughout the group.

Being the largest owner in the estate, he succeeded in inducing the directors and stockholders to adopt a scheme of division of a share of the profits with the men who had so largely aided in producing them. It was decided to set aside a sum equal to 10 per cent. of the net profits and to divide this amongst the laborers. As "Labor A/c" showed exactly the sum paid out to the laboring men in contradistinction to "Mechanics and Overseers," it was quite possible and simple to credit each man with a share of the allotted 10 per cent. of the profits. For instance, where the total of "Labor $\mathrm{A} / \mathrm{c}$ " was $\$ 90,000$ and a man's pay for the year was $\$ 180$, and the allotted sum for division was $\$ 9,000$, he would receive a credit of $\$ 18$. This was very encouraging to all employed, and gradwally the interest taken in the work by the majority of the men was quite apparent.

Strikes were not spoken of on this estate, as all employed knew that the manager, or owner, as he was considered, was in advance in thought for the welfare of all.

Probably the prime cause of all the friction between capital and labor throughout the world is the cupidity of capitalists or employers to screw down the producer to the lowest living share of what he has earned. Of course there are other causes, but this grasping feature of mankind is the mainspring of the friction, and to it can be charged the poverty and crime of the masses.

Five hundred and fifty years before Christ, Confucius taught, "Do not unto others what you would not have them do unto you."

Christ, speaking to a livelier people, taught, "Do unto others as you would have them do unto you."

An obedience to this latter command would remedy all the labor troubles.

But the millennium is not coming in our day.

The cupidity of the capitalist is also the cause of the different Unions which have sprung up. These are right in principle, as single-handed the mechanic or lahorer is helpless to compel recognition of his worth or essentiality to the pros- 
perity of the business in which he is engaged. Unfortunately, these Unions are led into taking part in politics, and matters which were not thought of at the instant of their being formed; and men are easily led by demagogues to do those things which react on themselves to the great distress of their dependent wives and families.

If capitalists would unite and carefully consider and recognize the services of those who have augmented their capital to such an enormous degree, there would be fewer strikes, and the distress of innumerable families would be largely mitigated.

Will this come in our day? It does not appear likely; and on the contrary, some men prognosticate a great war between capital and labor, and which may result in even radical changes in the forms of governments. It is to be hoped that wisdom will prevail, and that these two elements, so essential to each other, will be amalgamated. 



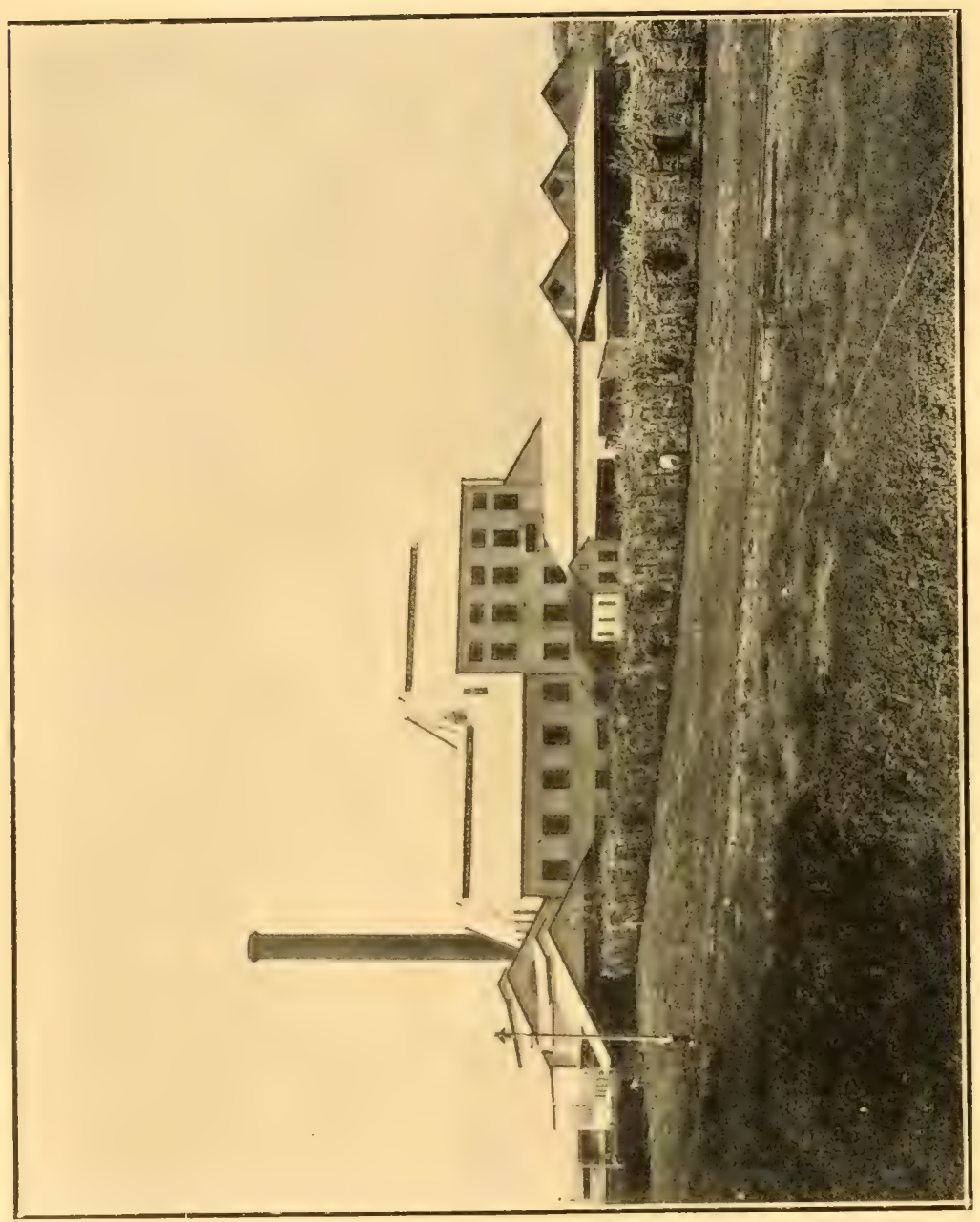

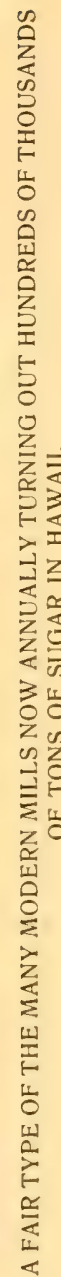




\section{CHAPTER XXX}

FASCiNATING SMALL FARMiNG APPLiEd TO A BIG PLANTATIONWheAt, CORn, POTATOES, BUtTer, Chickens, hoNey.

$\$ \mathrm{~S}$ has been several times remarked in this story of Breed's life in Hawaii, he continually noticed the lack of economy as practised in sugar culture on every plantation he had visited-but he noticed the same thing everywhere. In Honolulu he had seen the dependence of the population on importations of almost all the foodstuffs. With the exception of taro and a limited number of kinds of vegetables, every thing was imported, even to the corn and chicken feed. In the east the farmer raises every thing needed for the house, whereas in the west "ranchers" made specialties of wheat and barley and purchased their potatoes or butter.

The plantations appeared to be restricted to raising cane, and if any one deviated from that he was criticized and his conduct made the theme of letters of neighbors, who prognosticated all manner of ruin that would follow.

Breed's establishment of a nursery from whence he was enabled to transplant thousands of trees, both ornamental and fruit, did not escape the condemnation of carpers. With very little labor he cleared off some of the uplands and raised corn and wheat in sufficient quantities for the use of the management and laborers. It was admitted that it was nice to have fresh cornmeal; and this was appreciated by all the surrounding inhabitants, who, for a slight charge, were able to procure it. His people were easily induced to plant corn and sunflowers in their little gardens, and by this means to have a plentiful supply of food for turkeys and chickens as well as the "gentleman who pays the rent."

A matter that he was very familiar with was the cultivation of bees, and he determined to introduce them. In Kansas he had learned from a German neighbor a practical knowledge of the bee and its value in domestic economy. So much is it appreciated in Germany that no schoolmaster is given his 
diploma without first passing an examination on bee culture. Prizes are given by the government annually to the best apiarian, and every endeavor is made to encourage the art. Bees are one of the most useful and lucrative appendages of the cottager. They produce profitable results at a tritling expense, and in the tropics, where they can work throughout the whole year, a scientific knowledge and management of them should pay a thousand fold on the outlay. They were imported from Europe to America and have now spread over the whole Union. The science of bee culture has had more written about it than probably any other, the habits and nature of the insect having absorbed the attention of many of the greatest philosophers. It is not the intention here to go into a discussion of the history of the bee in Egypt, Greece, Rome or of the Russian or Tartar tribes whose whole dependence is on this insect. Like anything else the American takes hold of, he has invented and taken out patents for the hives, frames, breeding boxes, mailing facilities, guide comb. honey extractors, etc., innumerable, and cultivates the bee better than it is done in any other country.

Breed imported twenty hives and placed them in charge of a Chinaman, who, under his instructions, made a success of the venture from the beginning. In a year he had over a hundred swarms, and he distributed them in small colonies throughout the estate in sheltered places. He soon had more honey than could be consumed on the Islands, but the markets of the world have never been surfeited with this commodity. He found that by a little tact he could keep them producing honey continuously, and deprived them of their entire product. Molasses was of little value and made a good bee food in exchange for which he took their natural store. By artificial feeding and returning the comb from which the honey was extracted, they gave all their attention to the production of honey and none to wax. The hive produced from 200 to 600 pounds per annum, which was mostly shipped to the markets of Europe and the United States. Without enlargement on the many innorations introduced by Breed, the reader can see the extensive field an ideal agriculturist had here for improvement.*

* The Pacific Commercial Advertiser of March 28th, 1908, published the following report, the reading of which will prove interesting and 


\section{CHAPTER XXXI}

"AND OF ALL THAT THOU SHALT GIVE ME I WILL SURELY GIVE THE TENTH UNTO THEE"-GEN. 28:22.

$\mathrm{F}$

ROM his boyhood Breed had been in the habit of giving one-tenth of his receipts to support religious instruction. His parents, old-fashioned Methodists, had always done so, and his mother had impressed on him the value of so doing so strongly that Allen had always given a part of any gifts or presents he might have earned to the Missionary Society or his mother's church. He decided to follow up that principle through life and from his small salary as a teacher in a country school in New York he laid by one-tenth. The particular disposition to be made of this money he retained control of ; that is, he gave to any church he pleased, either the one most in need or the one which appeared to be doing the most good for mankind.

From his tenth year, when he began to keep a diary, he kept a cash account. This was expanded in Kansas into a regular set of books, and amongst other accounts on his ledger he kept "Religion" account and "Charity" account. These

profitable to any one interested in the honey industry in the Hawaiian Islands:

From Aristotle to Honolulu, Dr. E. F. Phillips last evening, at the University Club, rapidly reviewed the history of bees, honey bees, and the speaker, who is one of the big men of the Agricultural Department at Washington, held the close attention of about half a hundred prominent men, a number of whom are interested in bee culture, telling them what he had observed during his stay in these islands and the opportunities afforded here.

It will be remembered that not long ago there was on the mainland an official eriticism of certain Hawaiian honey exports, the declaration being that the honey sent out from these islands was not $\mathrm{A} 1$, the inference being in many minds that it was suggested that Hawaiian honey was adulterated. This was explained by Dr. Phillips as being perhaps on account of the shipment of what is commonly known as honey dew. A declaration of the fact, he thought, would avoid any trouble as far as the food and drug law of 1906 is concerned, and the speaker ad- 
were not blended into one, and he always had a definite distinction in his own mind in regard to them.

One-tenth of his earnings went to "Religion." He did not hesitate to charge up to this account any money paid for subscriptions for religious or non-sectarian periodicals and always endeavored to pass such on to the neighbors for such edification as they might give. However, he considered the fund sacred, and never used it but for the purposes for which it had been set aside, and this, too, as quickly as an opportunity afforded for its distribution.

In after years, when his income had become enormous, his "Religion" account swelled to large proportions. Struggling congregations in the west were frequently in receipt of money assistance whose donor was unknown to them. Missionary Societies in many parts of the States, as well as on the Islands, were assisted. A number of island churches were enabled to make necessary repairs through his help.

His other account, "Charity," had no credit side and was always closed annually into his private account. His attention was frequently called to orphan children or children of poor parents, who, if the opportunity was given, might be made into sood citizens. Many such he was able to clothe and place at boarding schools.

On many occasions where the heads of families were disabled by accident or disease from supporting their families he had paid them regular pensions.

vised, by way of a test case, that someone here send a tin of honey dew to some friend in the mainland States with the explanation that it was honey dew, or what is so-ealled, at the same time advising the authorities of his action.

Just before Dr. Phillips left Washington he had a talk with the solicitors of the department, and the opinion was given him, for he asked the question in anticipation of some such explanation being of advantage here, that as long as the truth was told in regard to the nature of the goods there could be no prosecution under the food and drug act.

Dr. Phillips said that he had risited the islands of Hawaii, Maui and Molokai, besides looking around this island, and everywhere he had been shown, as much as his limited time would allow, what was being done in the bee line. He had observed in every cane field the presence of the leaf-hopper, and he said that the leaf-hopper was known for the sticky secretion deposited on the sugar leaf.

Such secretions, the secretions of the leaf-hopper and other insects, 
So many had thus got on his pension roll either as students or decrepit that he feared in case of his death they would suffer. To avert such a catastrophe he had insured his life in a large sum payable to the executors of his will, in trust to continue these benefactions. Men called Breed "lucky," and asserted that anything which he undertook prospered, some saying they would like to rub their hands on his back to obtain some of his luck. Perhaps proper economy, industry, and a use of the intelligence with which they were endowed would have produced like results in their cases.

Breed never forgot that he was a member of society and that it was his duty in life to be interested in the welfare of his neighbor. The little kindlinesses which a whole-souled man can sprinkle along his path as he goes through life will spring up like flowers by the wayside for the enjoyment of himself and his fellowmen.

To be interested in the maintenance of good schools throughout the islands, knowing the immeasurable influence they have on the coming crop of citizens, was natural to Breed. A kind word to the teacher of a remote school or a little lecture to the scholars was always appreciated. A little spared from his "Religion" account went far towards embellishing country schools with the adjuncts in the way of maps, globes, flags, etc., which make a school attractive. Further than these, however, went the knowledge of each child that

were gathered by the honey bees at times and were responsible for the honey dew product as distinguished from honey proper.

Not that he desired those here interested in bees to become alarmed, but Dr. Phillips wanted particularly to draw attention to the fact that there was a more or less universal bee disease to be warned of. At present, as far as he was able to observe, there was no such disease among Hawaiian bees. The bee plague to be on guard against is what is known as foul brood, a micro-organic affection most disastrous to the culture. It affects the developing bee and is present in nearly all the States. The chief avenues of danger are in the importation of queen bees and their retinues and in imported honey which may be used in assisting local bees.

Dr. Phillips was of the opinion that Hawaiian honey was sold at too low a price. He mentioned that the honey industry, while nothing great, meant a matter of some $\$ 2,000,000$ a year on the mainland. Americans, he said, excel in the matter of practical application of scientific facts to bee culture. Europeans, especially Germans and the French, were away ahead in the science of such, discovering the facts taken advantage of by the Americans. 
a great man was interested in his or her welfare and was always willing to return the salute invariably accorded him by every scholar.

Knowing also of the benefit a community, consisting so largely of laborers, could receive from the services of a good physician, Breed considered it a very proper way of disposing of a part of his "Religion" fund by supplementing the small salary of a country doctor. It gave him some influence with the Board of Health in recommending appointments as government physicians. Their work in ameliorating the condition of the poor cannot be over-estimated. The natives are very amenable to treatment, their diet being simple and their diseases being naturally of a simple character. It was rarely that the islands were visited by any epidemic. The regular visit of the physician to each little village was looked forward to and the mothers presented their clean children for inspection with pride and accepted such advice and remedies as the doctor gave them. 


\section{CHAPTER XXXII}

THE BALEFUL EFFECTS OF ALCOHOL ON THE NATIVE-THE OLLA

A TEMPERANCE AID.

A

NYONE acquainted with the history of the islands knows of the baleful effects of alcohol on the natives, and all who have had to do with the red races know of the uncontrollable desire they have for any drink which will cause intoxication.

Nature seems so prolific in furnishing so many sources for gratifying this desire, that some are free to argue that alcohol is one of the gifts of the Creator and made to be enjoyed. This may be so, so far as enjoyment goes, but the red men, and many whites, having indulged somewhat, are thereafter incapable of restraint and will debase themselves, committing all manner of lewdness and waste their substance to the detriment of their families.

Breed was extremely solicitous that, as far as his influence went, he would endeavor to wean his people from intemperance. For them to merely know that he was set against the use of alcohol would cause them to conceal the use of intoxicants, and the use thereof in a surreptitious manner would be greater than the open obtaining of the wherewithal to make drunk come. He believed in local option, and that if a community wished saloons to be opened that they had the right to have them, and vice versa.

No saloons were permitted on the island, and yet very much alcohol in different forms found its way into the camps and throughout the island.

The women in their huis used their influence against it, but still the use of it increased.

In ancient times natives had made intoxicant drinks from fermented starches, found in any form, principally breadfruit, ti-root, and sweet potatoes. The white man went a step farther and taught them to make alcohol from these fermen- 
tations, and this was a more acceptable and speedy method of causing intoxication.

They used much awa (piper methysticum), which was chewed up and the saliva strained and drank. This was a miserable intoxicant, paralyzing the nerves and rendering the participant utterly helpless for some hours. It was said to be a good remedy for a certain skin disease, but one had to continue the use of it for such a time as to note its constitutional effects; and the stages gone through at times caused a most repulsive appearance in the awa drinker.

The white man's example and influence went far towards leading the red man in either direction, and it is unfortunate that it had largely been used towards their destruction.

When Breed was established as an apprentice on the plantation of which he afterwards became consecutively manager and owner, he frequently yearned for a drink from that old olla which lung on the branch of the live-oak in Grass Valley. They had brought two of these clay ollas amongst their effects when coming to Honolulu, and Mrs. Breed packed one of them very carefully and sent it to him. He hung it in the lanai of his cottage, and it acquired quite a reputation amongst the mechanics at the mill as a well from whence one could always obtain a drink of pure, cold water. In fact, it had the effect of attracting men in the evening to that part of the laborers' quarters, and slowly this grew to be a place where men sought each other's company.

Perhaps they liked to hear our hero expatiate on John Brown's actions in the bloody affrays in Kansas, and which ultimately led to the war of the rebellion.

When the niews arrived of the assassination of Mr. Lincoln, men came in from several of the surrounding plantations, and it appeared as if a great grief had stricken each individual.

Having "Kansas" with them, and having heard so much of John Brown and his martyrdom, "Kansas" appeared to them to be the connecting link between the two great martyrs. With his great reading, his unsophisticated ways, and his fine command of language, "Kansas" was a natural leader, and no one left his little circle without feeling that in his innermost soul he had been benefited by the conversation.

They often joked with each other, "are you going up to the 
Kansas club tonight?" and it eventually grew to be the proper thing to call on "Kansas" on Tuesday and Saturday" evenings. It was beneficial to "Kansas" also, as he felt impelled to keep in advance in his reading in current literature. Afterwards, when he became manager, he provided a large room, which was well supplied with literature, especially in the form of magazines. 


\section{CHAPTER XXXIII}

THE TELEPHONE PUBLICLY USED ON MAUI BEFORE IT BECAME

GENERAL IN THE UNITED STATES.

$\mathrm{W}$

HEN the telephone was introduced, which, by the way, was first publicly used on Maui, having sprung across the continent from New York and was in popular use on this estate before it became general in the United States, this room was called the telephone office. The boys said, because "they tell funny things there."

When the amalgamation of the several plantations was effected, Breed saw the desirability of having many of these offices, as the telephone was a great time-saver and was conducive to economic management. He either improvised an old house or built a cheap one for the telephone office in each of the villages of Mraikapu, Wailuku, Maihee, Kahului, Paia, Hamakuapoko, and Haiku, and in several of the camps.

Here he established a man at a small salary and encouraged him to keep a supply of periodicals and a stock of mineral waters, cigars and light refreshments, not forgetting an olla with its pure, cold water. Each of these was kept in a cleanly, orderly manner, and were places of resort for not only the attaches of the plantation in the ricinity, but were looked upon as public reading rooms in their respective neighborhoods. The men in charge were not only satisfactorily paid, but often made as much more from the profits on temperance drinks, refreshments, etc. These positions were therefore sought after, but were given as rewards to faithful sub-lunas, or as pensions to such as became crippled in the service of the estate.

The congregating of the men in these clubs, if we will use the term. was on the whole beneficial to the management, and the manager was enabled to gather much information from the observation of the men in the fields. It frequently happened that the first information of the ravages of any pest, or the lack of any essential in the soil of a locality, or the discovery of a variety of cane, was first obtained at these places. 
Maui was not an ideal heaven, and crimes were committed there as in other places, but the detection of the perpetrators through the net-work of these telephone offices was much facilitated. It was frequently remarked that East Maui was the easiest policed of any part of the islands, which was largely due to the temperate habits of the inliabitants. "Kansas," or Breed, attributed this state of affairs to the old olla, whose predecessor hung in the evergreen live-oak at Grass Valley.

Breed came to the conclusion that the best way to promote temperance was to educate the children and people in such manner that the habit of using intoxicants would not be acquired. He believed in police restriction, preventing the establishment of saloons, and that they should only be opened where the community allowed them to be.

He saw the futility of attempting the prevention of the manufacture of intoxicants, and recognized that nature had so bountifully supplied the material. Also he admitted that temperate use of wine or beer was the opposite of prejudicial to the health and longevity of the human race.

It is unfortunate that the vast amount of nutritious food contained in grapes and cereals should be destroyed through converting the same into alcohol, which itself is so destructive in its effects on the morals and health of mankind. "The wine of Hymettus was scraped from the bottles" is the record of Homer. Champagne and other wines require no scraping from the bottles. The wine of the ancients was therefore food of the highest quality, and the making of such was merely the preserving of the excess of one season's crop of fruits against the off season, or for portability in transportation.

In converting this food into our modern wines, fortified with alcohol, have we improved on the system?

Chemists assure us that the juice of the grape more nearly approaches the constituency of human blood than any known natural product. It would appear from the facility with which the grape grows in every terrestrial zone, that it is marvelously adapted for food. The grape cure, i. e., the living on grapes alone for a definite period, has the effect of changing the constitution of the individual, producing a clean skin and improving the digestion. 


\section{CHAPTER XXXIV}

THE PRIMAL CURSE APPLIED TO CANE CULTURE-MANUFACTURING

AND MARKETING THE SUGAR.

$\mathrm{B}^{\mathrm{r}}$

RED realized the necessity for economy in every branch

of the business of sugar culture. The great waste he had witnessed on Oahu, at Lahaina, Wailuku, and on this estate had impressed on him the importance of saving his crop and realizing the highest market value for it. Immediately on becoming owner he had severed connection with the Honolulu agents. They were exceedingly suave and endeavored to show him the advisability of maintaining an agency in Honolulu for the convenience of purchasing supplies and as a forwarding factor. He would have none of it, and proposed to ship his crop direct to the coast, and, if possible, sell it direct to the consumer. He made only two classes of sugar, No. 1 and No.2, and molasses.

He did put up an extra quality of No. 1, made by washing the sugar while in the centrifugal, and which was a very simple process. This washed sugar, being sweeter than refined sugar, readily found a market west of the Rockies. He made arrangements with a firm in San Francisco which had an exceedingly extensive connection throughout the States of California, Oregon and the Territories of $\mathrm{IV}$ ashington, Idaho, Montana, and Arizona, who agreed to make a specialty of putting his sugar into every retail store throughout those regions. His kegs were to be found in every mining camp west of the Rockies, and his No. 2 sugar was used in all the fruit canneries.

His molasses, not having been robbed of all saccharine matter, was in extensive demand. Much of the molasses, however, was used on the estate. Cattle and horses were very fond of it, and combined with ordinary cane tops it made a very fattening and strengthening food. It was remarked that his cattle, when turned out after a season's work, were in better condition than when first brought in. He found 
that they became exceedingly fond of the diluted molasses when it arrived at a state of fermentation and would "get drunk as lords." It was necessary, therefore, to keep all the feeding troughs frequently cleansed with pure water.

Molasses was also extensively used in mixing cement, of which great quantities was required in making cement walks, which repaid the outlay as conservators of water. In a dry region it is very essential to catch the frequent showers, and many cisterns were built for this purpose, to which these cement walks led.

As Breed's output reached the 100,000-ton per annum mark, he was considered one of the factors in the world's sugar supply, and he was continually besought, both by correspondence and personal visits of capitalists, to combine with them in erecting refineries and controlling the sugar market, so as to be enabled to milk the market ad libitum. This was contrary to his principles, but they had so much influence with Congress and succeeded in either threatening the repeal of the reciprocity treaty or in putting up the tariff on foreign sugar or in lowering it that he was finally compelled to cooperate with them. This eventually required a change in the manufacture of sugar, in that it was necessary to convert the whole output into as portable a shape as possible. Thus wooden containers were dispensed with and the whole tarry mass was sacked in jute bags and shipped.

The changes which had occurred in the manufacture of sugar from the time when he first witnessed the cultivation on Oahu were something enormous. Lands which had produced a satisfactory crop of two and one-half tons per acre were made to yield six and eight tons. When boiling in open train, as he first found the procedure, it was good boiling to obtain 66 per cent. in weight to the weight of juice. By the latest appliances in cultivation and machinery for extraction and boiling in vacuo as much as 90 per cent. and more was obtained. Not only was a great saving made in this direction, but the matter of fuel and other expenses was largely reduced. Formerly wet trash from the rollers was spread over a large surface on the mill grounds for sun-drying at considerable expense, and which was afterwards stored in immense trash houses to shelter it from the rains. Now it went direct to the furnaces after coming through triple sets of rollers, and being 
merely damp enough to burn better than chemically dry trash would burn. Thus an immense quantity of wood was saved, and the forests to that extent spared.

Thus the enlarged crop was produced at a minimum of cost and was marketed at the maximum prices.

By using judgment in cultivating only such soil as was suitable, by allowing it to lie fallow at regular intervals, by cultivating it with steam machinery, by correcting it, by manuring it, and by selecting good seed from distant lands or other islands, by fertilizing the sprouted cane, by destroying the pests which battened on it, by economy in transporting to the mills, by obtaining the largest possible percentage of crystallized matter from the juice, and by shipping direct and obtaining the highest prices for his output, our hero was beginning to realize his dream of what should be the best mode of sugar culture.

Still he was neither quite satisfied with the latest inventions in sugar making nor with the manner in which the cultivation was done, and indulged in dreams of what electricity might do for the soil and also what it might effect in boiling or inspissating the juice. Truly, he was now supported by a cabinet of thoughtful, discerning men, whom he had selected, and who were all interested in the work, and from whose discoveries and inventions many useful methods and appliances were adopted. One, for instance, invented and patented a mold-board plow, another a trenching plow, and still another invented a cane-leaf stripper, which made play of what had been the most repugnant part of cane cultivation. This latter was a wire with a peculiar twist, which, being inserted and drawn downwards, cleaned the stalk at one dash without injury to the hands.

The primal curse, "thou shalt earn thy bread by the sweat of thy brow," seemed to follow cane culture, for as the extension of the fields progressed so the number of parasites or pests which preyed on the cane multiplied. Whether they were introduced or originated spontaneously, as weevils do in a clean warehouse, was a question.

The planters of the islands formed an association at whose frequent meetings these and everything else pertaining to sugar culture were freely discussed, each gaining something from the observations of others. An entomologist was em- 
ployed and the pests studied scientifically. Enemies of the pests were introduced, some of which, unfortunately, proved enemies to other industries, and some of the parasitic insects were destroyed. Encouragement was given to inventors of labor-saving machines, and amongst other inventions they produced was a cane-loader, which saved much time and expense. On lands where it was impossible to make roads the trolley carrier, so much used in the mining regions of California and Nevada, was introduced, and immense bundles were thus transported across ravines and impassable tracts to the railroad or mills direct. This brought in lands which had heretofore been considered valueless. By the aid of buoys and immense cranes sugar was shipped from what was deemed an inaccessible coast, and the out-put of the islands was increased enormously. The amount invested in the industry was appalling. It was at this stage when the labor question made itself felt, and it will be necessary to add a few political chapters to elucidate the measures taken to overcome the difficulty, and which, while not successful, were the means of subverting the Hawaiian monarchy. 


\section{CHAPTER XXXV}

NATIVE LABOR BECOMING SCARCE, EXPERIMENTS WITH MANY PEOPLES WERE MADE-A POLITICAL REVIEW.

$\mathrm{W}$

HEN the native labor was becoming so scarce as to be perceptible, some Chinese were introduced, who made admirable agricultural laborers. The King had enlarged ideas of increasing the people, and sought to introduce some of a cognate race. The attempt to bring East Indians failed, and attention was turned to the South Seas. Some of these were induced to migrate, but they proved a very inferior stock to the Hawaiians, and very inferior laborers. Portuguese from the Azores were brought in and answered the purpose of laborers well, but the cost per capita was too large to warrant bringing more. A colony from Norway was brought, but they had not been carefully selected from the rural districts, and it proved a failure.

Some Germans were landed and were made to feel as much at home as possible by the establishing of German schools and churches, but they found that labor in the canefields of the tropics was not suitable for them. They could do most of the work, barring stripping cane and irrigating. The former destroyed the hands, and the effect of puddling round in water destroyed the feet, of the heads of families, and slowly they obtained better positions or left the islands for the mainland, or returned whence they came.

A treaty with Japan was made and some laborers brought from there. These answered admirably as workers, but to their introduction has been ascribed the downfall of the monarchy.

The British sovernment had placed a taboo on the departure of any Chinese from the port of Hongkong, or from any Chinese port within two hundred miles thereof in British bottoms under contract-and Chinese laborers were thus unobtainable. This was exceedingly unfortunate, as this people were content to work for low wages and had no political aspirations. 
The King had obtained a treaty of reciprocity with the United States which gave great encouragement to the sugar industry, but which naturally destroyed the commerce between the islands and Europe. This treaty was afterwards emasculated by the admission of sugar from all parts of the world free with a two-cent bounty on home sugar, McKinley tariff. The King visited the States in order to see if the reciprocal nature of the treaty could not be made good either by a bounty or otherwise.

While in San Francisco the King died, and his sister took the oath and became Queen. Although the King was not a model man, as princes ordinarily are not, still at heart he wished the welfare of his country and had advanced views towards that end. He was frequently led astray by following the advice of adventurers, but when cornered he tried to make amends.

His sister* was of quite a different stamp, and, forgetting what century she reigned in, began with her ascension of the throne to dabble in politics, and sought to introduce measures such as licensing lotteries and opium selling, which the better element knew to be subversive of good morals. Having threatened to abrogate the constitution, which she had taken an oath to support, and to promulgate a new constitution, a radical element in the city of Honolulu sent word to her that she was removed from the throne, and established a Provisional Government.

Immediately a Commission was sent on to Washington tendering the annexation of Hawaii to the United States. The naval officers of the great powers of England, France and America had long understood the value of Hawaii as a strategic point in the mid-Pacific, and had urged their governments to secure the possession of the group. England and France had signed a treaty that neither of them would

* Any political bitterness which may have been felt toward Queen Liliuokalani vanished when she made her declaration of loyalty to the United States in the jubilee number of the Advertiser, July 2, 1906. Since then her old foes have been first to wish her well, and they will not withhold their congratulations on this her seventieth birthday. Her Majesty is an influence for peace between the races living in Hawaii and for good Americanism. When she rides through the streets of her former capital today, she will not lack for respectful greetings.-Pacific Commercial Advertiser, Sept. 2, 1908. 
attempt to acquire the Islands, and America had given her assent to the treaty, but refrained from signing.

When the tender of annexation was made, the President signed a treaty of annexation, but it required the approval of the Senate. Before that could be obtained a new President was inaugurated, and he withdrew the treaty from the Senate and sent a Commissioner to Hawaii to learn on the spot the means by which the Queen was removed. Having satisfied himself that it was done by the assistance of the U. S. Minister and U. S. troops, he demanded that the Queen be restored, on condition that the principal citizens who took part in the revolution should be pardoned. To this the Queen refused to give her assent, and the Provisional Government continued.

A year and one-half after the formation of the Provisional Government, a Constitutional Convention was convened and a Republic was formed. Many thought this would continue indefinitely, but some of those largely interested in sugar continually urged the necessity of annexation of the Republic to the United States, giving as a reason that Japan, which had so many subjects residing in Hawaii, might forcibly take the country. On renewing the tender of annexation, the U.S. Government consented, and Hawaii became a part of the Union.

While the Republic was in existence permission was granted to Chinese to emigrate to Hawaii, if not under contract, by the British government. Under this permission over seven thousand laborers were introduced. This relieved the situation and the sugar industry again flourished. It is understood that in the tropics labor nutust be renewed every three or four years, the Chinese especially feeling that three years demands of them a rest.

Annexation knocked out the contract system in toto, and also excluded Chinese labor, and prices for labor soared upwards. Beet sugar was being manufactured in such quantities in Europe and some parts of the States that the price came down very materially, and Hawaii was "up against it," in vulgar parlance. Japanese, having found the road to Hawaii, kept coming in such numbers that it was possible to obtain the complement of laborers necessary, but at an advanced rate. 
It is in place here to tell somewhat to what extent the Islands are indebted to Chinese for the development of the resources of the country, and to speak of the unreasonableness of the U. S. laws in excluding them from a part of the world which needs their services, if on no other grounds. These laws have often been declared by wise and broadminded men iniquitous and un-American and a blemish on the statute books of the great republic. 


\section{CHAPTER XXXVI}

THE CHINESE AND THEIR RELATION TO HAWAII-VICES AND

VIRTUES OF THIS PEOPLE.

$\mathrm{E}$

ARLY in the nineteenth century Chinese began to arrive at the Hawaiian Islands. Kamehameha, the Great, opened a trade with China, sending cargoes of sandalwood to Canton for sale. It is thought that on some of these returning vessels a few came. Gradually the numbers increased until the sugar industry began to be prosecuted in earnest, when they came in large numbers, assisted by the planters.

They are quick at acquiring the native language, and many of them married native women. They made good husbands and fathers. Invariably they sent their children to China to live with the old folks and be educated in the language of the fathers. It is frequently remarked that the Chinese on the Islands are a superior class to those who have gone to California. This is not so, but, by reason of acquiring the native language, which was a medium of conversation with the whites, the distance between master and servant was overcome and we were enabled to discern their lines of thought.

They are exceedingly bright and have some admirable qualities, such as indomitable perseverance and industry and love of home. They are peculiarly a commercial people, although the masses are agriculturists. As merchants they understand thoroughly the benefit of combining their capital and also of maintaining their reputation for square dealing.

After the natives, they are preeminently the most dependable labor which has been introduced into the Islands. Once given to understand what is wanted of them, and they could be depended on to do it without threat or spur. A few of them were admitted to citizenship under the monarchy, principally for the reason that they were desirous of marrying native women, the old law prohibiting the marriage of a na- 
tive to a foreigner who was not a citizen. Many of them became Christians and reared their families in that faith.

A residence on the Islands improves them very much, and on returning to their own land, where the government is so far behind that of the occident, they continually urge reform measures.

The great love of this people for education, and their appreciation of good government, make them model denizens of the country.

The misdemeanors of gambling and opium smoking cover most of the sins of the Chinaman. The latter is abhorred by the majority, and its evil consequences are harped upon by their principal speakers and writers. Their love for children and the self-denial which they practice to send money to the old folks to maintain them and educate the children could be emulated by white men with advantage.

When annexation was being sought the Chinese, although constituting one-third of the population, took no part in the discussion, trusting in the leadership of the foreigner, whose wisdom they had learned to appreciate. They little dreamt of the baleful effect annexation would have on their trade, commerce and opportunities.

The Chinese have been of so much benefit to the Islands in so many ways that they are thoroughly appreciated. In every little valley a Chinese store may be found, which is a great convenience to the neighborhood, and at the same time the trade is insufficient to warrant a white man in opening such markets. In a thousand instances they have leased land which was apparently valueless and by their industry succeeded in reclaiming it and making it tax and rent producing property.

They control the rice industry of the Islands, but the coming of the exclusion laws bids fair to extinguish that resource, for the reason that further laborers are unobtainable, and, as in other fields, the rice cultivator must have a rest. They can not understand why they should be prohibited from coming and going as of yore, especially when the necessity of their labor in this tropical country is so apparent for the sugar and rice industries.

As a matter of fact, they were not taken into consideration by those political leaders who pushed for annexation, and the exclusion laws will not only exclude but will ultimately re- 
duce the Chinese population to a mere handful, there being so many of them dependent one on another. When told that the United States was too great a country to be suspected of intentionally annexing or marrying Hawaii with the ultimate result of destroying any particular industry, the Chinaman remarks that he fails to see the difference between the intentional or accidental when the result is the same.

The immigration laws of the United States may be exactly what is wanted in that country, but when the great republic spreads its wings and covers part of the tropics, it reaches a region where a class of labor is necessary which can not be supplied from the north.

There is no fear that there will ever be an exodus of Chinese from their own country in sufficient numbers to interfere with either the political or commercial prosperity of that great country. As America is looking towards China for a market for her manufactures and products, it would be advisable for her to be liberal with the Chinese to secure their confidence, and not to exclude the few celestials who may wish to visit the United States for a longer or shorter period. It is only with the intention of returning to Cathay that a Chinaman ever leaves his own country, and they will thus never interfere with the politics of America. In the meantime their labor is much needed in developing the resources of the country. 


\section{CHAPTER XXXVII}

A RESUME OF THE HISTORY OF THE HAWAIIAN ISLANDS-FROM

THE RISE TO THE FALL OF THE MONARCHY.

IT IS necessary to give a short resumé of the history of the Islands. The Hawaiian, or Sandwich, Islands were discovered by Captain Cook, the great English circumnavigator, in 1778. He met his death on the Island of Hawaii at the hands of the natives, while he was endeavoring to coerce the King to go on board of his ship. Cook had appeared to the natives as a god, and was called by them Lono, the god whom prophecy had stated would again come to the Islands. He had learned the language of the New Zealanders, which is very similar to that of Hawaii, and also to that of Tahiti, where he had rendezvoused for a period. Consequently he was able to talk to the people, which probably added to their idea that he was the returning Lono. He knew that he was worshiped by them and permitted it for ulterior purposes.

The hospitality lavished upon him was exceedingly onerous on the common people, who had to bear the whole brunt of carrying pigs, taro, and all kinds of food from very long distances to the part of the Islands where the ships were anchored. A boat from one of the ships had been stolen, for the sake of the nails in its composition, and Cook was anxious to get hold of the King as a hostage to secure the return of the boat. He had tried this scheme at some of the South Sea Islands and found it worked well. The Hawaiians were alert and scented danger, and advised the King against going on board.

When Cook attempted to use force, he was bustled by the natives, and one of them hit him with a stone. At this he groaned, and the illusion that he was a god was dispelled. He was quickly killed, but his body was recovered and taken to England. The statement that his body was eaten by the cannibals of the Sandwich Islands is as untrue as it is true 
that from Cook's visit came the seeds of death which have at this day reduced the nation to a tithe of what it was.

Cook's first officer estimated the poptulation at 500,000, and this statement is probably a fair estimate. It is not only so from a census taken at a later date, but from signs of cultivation on now unused lands that we are led to believe such an estimate was approximately correct.

Internecine wars, pestilence, disease, rum and its concomitant evil effects, together with the change from nudity and the enhanced toughness of cuticle engendered thereby to the adoption of clothing and its debilitating effects, have united to cause this serious decimation of the population.

Commerce has always followed closely after new discoveries, and during Kamehameha's reign a trade sprang up with China, which bronght to Hawaii, in exchange for its sandal-wood, some of the manufactures of that country. Furniture, silks, clothing, etc., began to be appreciated by the chiefs; and the common people were coerced by them into denuding the mountains of that commodity to supply their wants. Hawaii had nothing else to export. During his reign horses, cattle and sheep were introduced, and they have multiplied to the vast destruction of the forests which clothed the mountains as with a garment, and undoubtedly to the serious reduction of the rainfall.

By the aid of firearms procured from the traders, Kamehameha was enabled to reduce the whole islands to his sway, although he had formerly been frequently beaten in battle.

Finding his ships were compelled to pay large tonnage dues in China, he established a system of such charges and also began to levy duties on imports. He maintained a good government, where life and property were safe. He died in i1819, and was succeeded by his son Liholiho, who reigned until 1824; he died in England when on a visit there. During his reign the American missionaries arrived and the tabus were broken, the worst of which was the interdict against man and wife eating together.

Liholiho was succeeded by his brother, Kauikeaouli, who as Kamehameha III. reigned from 1825 to 1854 . During his long reign of twenty-nine years Hawaii advanced very rapidly in every way. Old and young were seized with a desire to learn to read and thousands became Christians. In 1852 the first consignment of Chinese coolies arrived to take the place 
of the fast decaying Hawaiians. Smallpox ravaged the islands from Narch to October, 1853, the number of deaths thereby being unobtainable. The first regular census was taken in that year, December 30.

This good king (Kamehameha III.) died December 15, 185t, and was succeeded by his nephew, Alexander Liholiho. He reigned but nine years, and died at the age of twentynine.

The postoffice was established in 1859, and many public improvements were begun during his reign. Alexander Liholiho was succeeded by his brother, Lot, who reigned as $\mathrm{Ka}-$ mehameha $V$. to 1872 . He was a very firm man and made a good sovereign.

King Lot did not appoint a successor, and the people elected his cousin, Lunalilo, who refused to be called a Kamehameha, feeling that he should have been appointed by his uncle, Kamehameha III. He probably would have been appointed but for his having acquired habits of intemperance. He reigned but one year, during which time he had a good cabinet and the country was prosperous.

Lunalilo refused to appoint a successor, and Kalakaua was elected. The people were defrauded of their choice, which was Queen Emma, relict of Kamehameha IV., by open and notorious bribery. On the announcement of the result of the special legislature, the mob assaulted the government building and gutted it. Some of the electors were killed and others injured * and troops were landed from foreign vessels to preserve order. He was in no manner connected with the Kamehameha dynasty, but belonged to a family of chiefs who had been subdued by the conquerer. He reigned eighteen years, during which time the country prospered and the sugar industry rapidly rose to first place. His motto was "hooulu lahui," increase the nation, and efforts were made in many directions to secure immigration, with only partial success. He was urbane, sociable, a pleasant after-dinner speaker, and capable of conversing intelligently on almost any subject. While encouraging instruction and not objecting to religious toleration. Kalakaua encouraged the ancient

* One died afterwards from the injuries he had received.

+ David Kalakaua was descended from Kameeiamoku and Keaweaheulu, aliis and counselors of Kamehameha I. 
practices of superstitious origin, such as kahunaism and the bestial hula. He visited Washington in 1874, and was the means of securing the reciprocity treaty with America. He traveled around the world in 1881 making the journey in nine months, and was royally received everywhere, although the intention had been to travel incognito. During his comparatively long reign many of the public improvements which meet the eye on the islands were inaugurated, such as the telephone system, steam fire engines, the palace, marine railway, Surveyor General's building, Police Station, Postal Savings Bank, and a new currency of the same weight and fineness as the U. S. silver standard. It would be impossible to please all the different factions, and his reign will always be remembered by the solid improvements effected, and forms a distinct epoch in Hawaiian history. Often he was led to do what he afterwards admitted to have been unwise, and when confronted with an aggrieved public he was willing to make admission of his errors and correct them.

David Kalakana diecl in California in 1892, and was followed on the throne by his sister, Queen Liliuokalani, who lacked the tact of her brother, and quickly brought about her downfall and terminated Hawaiian monarchy. 


\section{CHAPTER XXXVIII}

OUR HERO IN REVIEW AGAIN-EXPERIMENTS WITH ELECTRICITYMENTION OF NOBLE MEN AND WOMEN OF HAWAII.

D

URING the years of his management prices for sugar had steadily gone down on account of the great increase of the cultivation of the beet in Germany, France and the several States of the Union, and Breed was forced to study the situation with much solicitude.

In scanning the field, he saw that the land was producing much more than he had anticipated, that the crop was being harvested at a minimum of what the previous cost for cultivation and transportation had been, that the results in the mill were almost up to what he judged should be a proper percentage of crystallized matter to the weight of the extracted juice, and he saw that with the exception of obtaining the full price for his product there were but two ways in which the situation could be improved.

In his experiments with electricity, tried in a small way, he saw that it could be utilized in cultivation with the double advantage of destroying pests and of aiding the rootlets of the cane to form those minute bulbs through which the life of it was secured. Also, the value of electricity in the mill, not in lighting and in running small machinery only, but as an aid in the crystallizing of the sugar, both in time and in quantity, was impressed on him. He knew he had great resources of power for making electricity in the many ravines through which the immense aqueduct passed, and, although the loss in conducting the electricity to the fields and mill from a distance would be considerable, he felt in the future he would endeavor to make use of this power which nature had placed in his hands.

The other exception was in the excessive price he was paying for labor. Knowing so much of the history of China and the Far East, and of the myriads of people there who were barely existing, and of the gladness thousands of them 
would feel at having an opportunity to better their condition, he felt that it would be only right for him to make a strenuous endeavor to assist many of them to come to Hawaii for his own interests and as a humanitarian measure.

He had always followed the principle of employing white men wherever available, and confined the Asiatics to field work. He had practical experience in the field, and, although there were times when he felt that he could stand such work, he knew now that the actinic rays of the sun in the tropics had such an effect on one of northern birth and maturation that no acclimation would prevent the blood from becoming thin and unable to stand field work. He looked over his colony of Chinese and compared their situation to what it had been accustomed to in its native land. Large families of children surrounded every home, enjoying good health and opportunities for education. Largely they had cast aside the peculiarities which had distinguished them from others; and without queues or peculiarities of dress, with their neat homes embellished with foreign furniture, sewing machines, pictures, etc., they were assuredly becoming Christian in belief, as the increasing church membership showed.

It would take a generation to remove many of the superstitions which they had inherited. They had their clubs and debating societies, which they conducted as well and orderly as the best society in any part of the United States, and continually sought to increase their knowledge of the world. Hundreds of them were subscribers for American periodicals, and the parents compelled the children to read and translate then. It is unnecessary to state that many of them had good bank accounts, and were owners in the stock of the estate on which they were living.

No one knew better than Breed of the unreasonable and unnatural objection of the labor element in some parts of the States to the Chinese, and also of its far-reaching effect on Congress. While knowing this, and of the futility of attempting to cducate the masses in those parts, he felt that the circumstances were so different away off in the tropics that the obiections made to Chinese on the mainland would not be applicable. It was contended by the most radical of the leaders of the opposition to Chinese, that the sugar of the Islands was the product of Chinese labor, and therefore the consumption of it in the States was an encouragement to 
the detested Chinaman. The puerility of such an objection, and a more "dog-in-the-manger" attitude, could not be assumed. To those acquainted with the innumerable attempts to secure white labor in raising cane and the utter futility of such attempts, the manufacture of sugar in the tropics without the aid of people of other races seemed impossible. The former objection made to such sugar as being the product of "contract labor" had been done away with on the absorption of Hawaii into the Union.

When Breed had organized this immense estate, a number of his friends had taken shares in the stock, which had yielded them large returns on their investment, amongst whom was the Commissioner whose acquaintance he had made under such peculiar circumstances. They had kept up their friendship through correspondence, and when this climax, of dearth of labor, was reached, the Commissioner advised himi to come to Washington and he would be given an opportunity to explain his views before committees of Congress, and he decided to do so. In his methodical manner he collected all possible useful statistics, the archives of the government and of the Planters' Association affording ample supplies. To these he added views of scenery pertaining to the sugar industry in all its stages, and also interesting slides of prominent personages, trees, plants, etc., by means of which he was enabled to explain the situation.

No story smacking of Hawaiian history could be written without some mention being made of some of the noble men and women of the Islands. Preeminently among the chiefs stands out the name of Mrs. Bernice Pauahi Bishop, a daughter of the high chiefs Paki and Konia, and a direct descendant of Kamehameha I. She inherited almost one-third of the lands of the group. She married a banker, the Honorable Charles R. Bishop, and at her decease left all of her property to a trust, the proceeds and usufruct of it to be used for the education of girls and boys of her race. In this she was nobly aided by her husband, who has contributed from his own estate enormous funds to carry out her expressed desires. Having no children of their own, they can properly be denominated the parents of the race.

Another high chiefess most worthy of note was Queen Emma, relict of Kamehameha IV. She was a daughter of Kekela and a great-granddaughter of Kamehameha I. The 
Queen's Hospital in Honolulu will keep her name alive for generations to come. From her exalted birth, education and virtues, she will always be ranked with Pauahi. She was a friend of Breed, and told him of her travels in Europe and America. In describing her reception by Her Majesty Queen Victoria, and of Her Majesty taking her by both hands and leading her to a sofa, where they sat, he could realize two Queens of the earth sitting together, one the Empress of the world and the other the Queen of the smallest kingdom-two ladies with great thoughts for the betterment of their respective subjects.

We have told of the destruction of so large a number of chiefs at the time of the Hawaiian Armada on Maui, which no doubt militated against the eventual progress of the Islands. There were many, however, who lived in the day of the white man who were nature's noblemen, and whose genius and character were respected by the foreigner. 


\section{CHAPTER XXXIX}

THE SILVER WEDDING OF THE BREEDS WAS CELEBRATED BY A LUAU AND HOOKUPU OF GRAND PROPORTIONS.

$\mathrm{B}^{\mathrm{R}}$

REED'S friend, the preacher of Wailuku, had a golden wedding, the intention of the family being to have a function of a private nature, but at the same time to send cards to all their acquaintances as mementos of the occasion. The whole community would gladly have gotten up a most elaborate reception, as the aged missionary and his wife were dearly beloved by all the natives and foreigners who had met them. He was a man whom to know was to love, largely on account of his own loving, sympathetic nature. It satisfied the old couple to have their whole family around them and to make it an occasion when, probably for the last time on earth, they could consecrate themselves to follow in His footsteps.

It having developed that the twenty-fifth anniversary of Breed's wedding was approaching, the managers of the several plantations comprising the estate got together and made arrangements to give this respected couple a send-off the like of which had never been known on the Islands. The natives take great enojyment in a luau, and do not let the labor or expense in getting up the preparations thwart their intentions, when occasion offers. There were quite a number of sub-lunas on the different plantations who were natives or half-whites. The foreign overseers decided to leave to them the preparations for the luau, while they furnished the money to purchase bullocks, hogs, turkeys, chickens, fish, etc.

It was arranged that there should be a hookupu-i. e., a presentation by each guest of some gift as he or she thought fit or had the means to do. The natives, being lovers of gymnastic sports, it was deemed advisable to make a holiday of the occasion and to initiate horse and foot races, together with an exhibition of the games they delighted in, as boxing, wrestling, vaulting, ball-playing and other sports. 
The $3 \mathrm{rd}$ of July, the date of the silver wedding, coming on Monday that year, the hands were all given a whole holiday on the preceding Saturday, instead of the usual half-holiday instituted by Breed. This gave four holidays in succession, as it had been the custom from time immemorial on the Islands to celebrate the Fourth of July-at least from the advent of Americans. By means of the thorough organization established on each of the plantations and of the whole estate, it was possible to unite every man, woman and child in any undertaking which was popular, and the various committees to whom were assigned different parts of this fiesta did their work well, as the day proved. By means of the telephone, rumors were circulated to the most distant valleys of the island that every inhabitant was invited and welcome, without money and without price, to three days' enjoymentand they came.

Natives never go to a feast without having on "a wedding garment." This means that the women in each village, or hui in a village, shall procure dresses that will be uniform in color, and the men likewise dearly love to wear white pants and red shirt or black pants and white shirt, according as is decided in their meeting. Naturally all this required much preparation, but each felt repaid by the effect produced.

It seems difficult to formulate a description of this great entertainment from the uncertainty of what to begin at, as they say of a "round robin." Probably if we commence at the family to which center all converged it would be more apt to catch the majority of the persons and events taking part.

On Monday morning at ten o'clock, then, we find Mr. and Mrs. Breed surrounded by all their children and two grandchildren in the center of an immense lanai constructed on the lawn in front of the plantation house. The old preacher from Wailuku performs the ceremony of reuniting this happy couple, and offers a prayer that their future may be as much blessed as their past, both to themselves and to those whose lives have been benefited by coming in contact with them.

Then occurred the most remarkable event or incident of the occasion, and one that is peculiarly Hawaiian. Every man, woman and child had brought something as a present, and lines had been formed of this immense throng which pro- 
ceeded toward Mr. Breed, when each of them deposited his makana or gift.

One of Kamaka's fathers, who was an adept at making the feather kahilis, cloaks, and helmets used by the ancient chiefs, had made a mahiele or helmet which he presented to Breed. One in authority had sent from Honolulu a feather cloak. Breed was requested to don the helmet and cloak and thus as an ancient chief he stood to receive the people. Now came each village or society or individual in person in a long procession, and as each man, woman or child deposited his present, which was taken charge of by one of the lieutenants, Mr. Breed shook hands with him or her, until all passed by.

The gifts consisted of every imaginable article of Hawaiian growth or manufacture, and much from foreign lands. One old woman brings a net of hens' eggs, another a net of onions, still another a hand of bananas, a roll of kapa, a fish-net, a roll of dried lauhala leaves, several cocoanuts held together by a strip of the husk, eight men carrying a canoe with its paddles, a fine Niihau mat, a yellow feather necklace, a necklace of polished kukui nuts, an elaborate piece of lace work made from threaded koa seeds, an ancient spear, a pair of maika stones, a pair of stone pestles and a koa board for pounding poi, a baby's crib made from a great variety of Hawaiian woods, a magnificently polished kou calabash, a squealing pig, a turkey, a pair of chickens, a gourd of shell-fish, a span of beautiful horses from California, a handsome carriage, silverware innumerable, etc., etc. From his Chinese friends came boxes of tea, cigars, silk handkerchiefs and other embroidered silken goods, wonderfully carved ivory ornaments, black marble seated furniture. Probably as unique as any of the many presents was a frame made from fronds of the silversword plant, a present from Mary, the old parson of Makawao's daughter, or rather from her school. It encircled a verse. "Seest thou a man cliligent in his business, he shall stand before kings, he shall not stand before mean men." This was highly prized by the recipient.

Ladies from all parts of the Islands who had enjoyed the hospitality of the Breed mansion at different times prepared and sent in work of their own hands, knowing such would be more appreciated than purchased silver articles. 
The feather cloak and helmet have been mentioned, but to understand somewhat of the value of these articles one must know of the labor consumed in their manufacture. Two golden feathers are found beneath each wing of a small bird called the oo. These are assiduously collected until a sufficiency is obtained. The garment is woven of fine olona thread, during which process the feathers are woven in and the work is done in so remarkable a manner that each feather lies in place and as neatly as if carefully preened by the bird itself. Such a garment has such a pecuniary value that if reckoned as to time only it would be worth thousands of dollars.

Whence the Hawaiians obtained the pattern for the helmet, which is exactly similar to that seen in pictures of Alexander the Great, it is not possible to surmise. It may be that some of the shipwrecked Spanish navigators, shipwrecked according to tradition in the year 1527 , and who spent the balance of their lives on the Islands, may have instructed them.

It should be added that each visitor at the luau wore a wreath of flowers-maile, lauhala, or kikania fruit-which made the effect most pleasing. While the hookupu was under way a band of singers and musicians from Lahaina discoursed Hawaiian airs, which added much to the zest of the occasion.

During the hookupu the numerous stewards who had been at work from the previous Friday, were preparing the grand luau beneath an immense lanai erected for that special purpose. At two o'clock the drums beat a signal for the feast, and the assembled guests gathered into a vast audience to enjoy a luau the like of which had not been seen in that generation, and probably the last great feast which is likely to occur on the Islands. The lanai was one hundred feet wide and three hundred feet long, constructed of a wooden framework and thatched with woven cane leaves. The ground was covered with bulrushes from the swampy lands near the sea. There were three spreads in lieu of tables, running from end to end, composed of banana leaves. At each plate or place was set a bowl of poi, a bundle of fish, another of fowl, pig, or beef, together with shells of inamona and salt. At intervals stood dishes loaded with Hawaiian puddings of various kinds, interspersed with cut water- 
melons. Young cocoanuts for drink, as well as mineral waters, were supplied to every guest.

Mr. and Mrs. Breed and their family occupied the head of the center spread, and the foreign element lined either side of it. The Hawaiian men and women, alternately, occupied one spread, while the other was filled with Chinese men and women dressed in the gorgeous colors which the Chinese ladies love to wear. The various societies amongst the natives, in their brilliant colors, made, also, a charming picture.

After all were seated photographs were taken of the beautiful scene from different standpoints. These photographs were afterwards framed and presented to Breed as everlasting mementoes of the occasion, and were freely given to those who wanted them to keep as reminders of the Great Silver Wedding. The old parson said grace and the feast began, the stewards supplying every one with iced drinks and waiting on all. The musicians played many of Hawaii's sweet airs and sang a song prepared for the day, and when all were satisfied, the Kameliameha Hymm was given as a finale.

As the edibles and their preparation have been described in previous chapters, it is unnecessary to recapitulate; on this occasion they were gotten up in such vast quantities that there was enough and to spare, so that each one who wished was enabled to carry away large bundles of foodstuffs. As to the races and games which took place, and the dance in the mill in the evening which was kept up into the Fourth of July, it is unnecessary to enlarge upon them.

Suffice it, young and old had their fill of good things and gayety, and each on departing was the recipient from Breed of a sum of money as a donation with which he or she could procure a memento of this Silver Wedding. These sums of money had been placed in envelopes by members of Breed's family and were of all amounts, from $\$ 20$ down to $\$ 1.00$, and were distributed as addressed. The luan and reunion was a testimony to the appreciation which the people had for Breed, from foreigners and natives alike. He was a great lover of the Hawaiians, their history, manners and customs, and being so familiar with their language and traditions was more of a Hawaiian than the younger elenent amongst them.

The recipients of all this aloha looked back to their advent to the country and to some of the impressions they had formed, especially their feeling that they had made a grave 
mistake in coming to the Islands. Although their lives had not been all smooth sailing, they had weathered the storms and arrived safely in port.

The necessity of acquiring the language, and the language itself having been so frequently spoken of, it may be of interest to add a chapter on it, as philology has been one of the means by which the origin of the Hawaiian race has been traced or conjectured. 


\section{CHAPTER XL}

THE HAWAIIAN LANGUAGE-ITS LACK OF HARSH CONSONANTS

MAKES IT EASILY ADAPTABLE TO MUSIC.

$\mathrm{T}$

HE language of the people of the Hawaiian Islands is a peculiarly soft one, and as written, the vowels have the European pronunciation. Its lack of harsh consonants, or even sibilants, makes it very adaptable to musical expression. Evidently it has a common origin with that of the Maoris of New Zealand, the inhabitants of Tahiti and some other of the groups in the South Seas, although it differs from all of them in certain radical respects.

It is said that the Maoris boast of having gone there from Hawaii, while the traditions of the Hawaiians is that they themselves came up from the south. In comparing the nomenclature of many matters pertaining to all the Pacific islands, we are struck with the uniformity of names, as water, wind, fire, hand, shadow, tree, canoe, and names of parts of islands which face the same direction of the compass. One would say, why doubt that the Polynesians have a common origin? If it were not for the great distances between many of these groups and the fact that in ancient times large vessels or those capable of traversing a stormy ocean were unknown, the migrations of the ancients might be accounted for. While the roots of many words in the languages of the various groups are the same, the prefixes and affixes differ, making the sounds to differentiate.

As has been stated, many of the traditions and genealogies of the Hawaiians were converted to music, and through the canticle or chant more freely committed to memory. The thoughts of the natives run to poetry, and seldom will they engage in conversation without quoting some lines from the ancient meles or chants, probably to better express their ideas.

All speaking is accompanied with gesticulations and perhaps genuflexions of the body. Often the most innocent 
commonplace expressions are given a meaning quite the reverse of the words by a cast of the eye, or a wink, or innuendo, or motion of the hand or body. To say, for instance, that "you have been a great traveler about the islands" would probably be considered a compliment by us, but it would depend on the speaker or the one spoken to and the accompanying look or action. It is said that many of the verses composed and sung in the church were intentionally put before the public for the sake of continuing the double entendre applicable to them, and in derision of the teachings of the early missionaries.

To give an example of a comparatively innocent song, which was very popular in its day and is known to all the Hawaiians, a verse of it is given together with a free translation. The mele is rery long and without any gesticulations or motions is a poem, but amongst the natives the words and motions convey extremely suggestive thoughts. Kilauea was the name of one of the early steamers running between the islands and a very great favorite amongst a people who travel as much as they do.

\section{KILAUEA.}

No Kilauea ke aloha la;

No ka moknahi o ke kaona la.

Nana i ka iue o ka moana la, Ale ku ehu o Pailolo la.

Mea ole ke loaa o Hawaii la, I ke kue no mea ka huila la. $\mathrm{E}$ aho ke hoi i ke keena la, I olu pono iho kaua la. Ko mai lukini onaona la; O Kaleionehu he inoa la.

In memory of Kilauea the beloved;

The steamship of the city.

Hers is the track in the ocean, In the surging billows of Pailolo.

The trip to Hawaii is nothing, On account of the force of her serew, It were better to adjourn to the cabin, Where we will be more comfortable. Pass the fragrant cologne (gin), In memory of Kaleionehu.

At the time of the coronation of Kalakaua, many meles or chants were composed or brought forward from those 
which had become obsolete, some of which were the composition of the King. To all appearances they were innocent poetry. On inquiry from some of the older of the natives their true inwardness was discovered. In fact it would not be polite to use the printer's art preservative in attempting to give the exceedingly filthy meaning of these songs. Suffice it to say that in the old barbaric times Phallic worship was the order of the day, and from young to old sensual delights were the theme of all conversation, and the $\mathrm{Ha}$ waiians will require several generations before they are weaned from the love of dwelling on subjects which to us are so repugnant.

Our hero once questioned an old native as to the meaning of an oli or chant which he was singing, and the old man said it was a description of a beautiful fern-clad precipice so restful to the eye of the weary traveler, the protuberances of which were covered with minute ferns. It would require a stretch of imagination to see in this anything that was suggestive, but the motions of the eyes, the gesticulations of the limbs, and the sinuous contortions of the body spoke volumes. The wild, weird music of the Hawaiian songs has a charm, whether from a chorus of voices or as frequently heard from man or woman in their travels up and down the ravines or mountain sides. Tourists visiting the islands are captivated with it and seek the services of the good quintette clulss so numerous in the capital. They are unaware that many of the novel melodies which are sung with an abandon similar to the bacchanalian orgies of the age of Nero, are replete with the sensual thoughts of the composers.

The love of the Hawaiians for music is proverbial and children at the schools readily learn English songs, from "rag time" to the most solemn of our hymns. A custom has grown up on the Islands similar to the carol singing of Germany and England, and on the evening preceding any holiday many groups of singers go from door to door in the city or country towns singing and playing instruments. They have been much encouraged by foreigners, who invariably go out and give the leader money or wine or foodstuffs, as the case may be. They are very clever in their way, and at a German's residence will sing "Die Wacht am Rhein," or at an Englishman's "God Save the Queen," or at an American's "The Star Spangled Banner" or "Dixie," as they think will 
be most acceptable, after giving a number of their own pretty airs.

The government band is largely composed of natives, and is one of the favored institutions of the country, never failing to get an appropriation from each legislature. It has been under the leadership of a German sent out by the Emperor to the King, for the past thirty years. Having had a military training he is a martinet for discipline, and although the natives can not tolerate discipline as a rule, his men submit willingly, some of them having been in the band from his advent. He has composed many beautiful airs for which words have been supplied by Kalakaua, the late Queen and others of the nobility.

The band has been carried to San Francisco, where at a great conclave of Knights its music was much appreciated. Several of the Hawaiian quintette clubs make tours of the United States, where their services are in demand at some of the large hotels, and their strange music is a novelty.

A knowledge of the language is quickly acquired by the Europeans settled on the Islands, excepting perhaps the English, many of whom have not that quick ear for discerning slight variations in sounds of the rowels. Some rare mistakes have been made by them, but the Hawaiians, who are as polite as the French, refrain from laughing at errors of foreigners. For instance, an English Bishop, who wished to show his application in studying the language, proposed to read the commandments. "Thou shalt not steal" in native is "mai aihue oe," but he said "mai ai hua oe," thou shalt not eat eggs or fruit"; and again, "lay up your treasures," "e waiho ko oukou waiwai," he said "e waiho ko oukou wawae," lay up your feet. The slight distinction made all the difference, but in a foreign congregation such readings would at least have provoked a smile.

The native ear is exceedingly sensitive to vowel sounds. It is more than probable that the original language of all the Polynesians had the vowels separated by consonants, much more so than that of the present, they having been dropped for euphony. Ae, ai, ao, ea, ee, ei, ia, ie, io, for instance, are in some of the dialects, ake, aki, ako, eka, eke, ika, ike, and iko.

The Hawaiians have no word expressing gratitude, no name for son, child, aunt, uncle, and there are many other 
words that might be recalled for which they have no exact expression. Child is little one, and male child is little male; aunt and uncle come under the head of parent.

There are no swear words in the language, an aggravated native being merely able to make some expression pertaining to the body.

Some of their words are very quickly adopted by foreigners, the word tabu, for instance, having been assumed into English. Residents use many of the native words in preference to English, even in conversation amongst themselves. One particular word is "pilikia," whose meaning is so broad that it covers everything. Any difficulty, distress, danger, accident, row, death, breakdown to machinery, sickness, inability to fulfill contract, entanglement, is denominated pilikia. The polite native, instead of laughing at the foreigner, endeavors to meet him half way, and also uses the word, although quite capable of expressing the finest distinction between the above quoted expressions in the vernacular.

A diligent study of the language by one of the earliest missionaries convinced him that it was one of the oldest languages extant, and instead of being a pigeon tongue was very exhaustive in its vocabulary, anything being capable of being expressed in it. One student of philology asserts that it has many words and more root words similar to those of the Sanscrit. Through the language and customs and type of the people he surmised that they originated in Syria, and from there came through Egypt, India, the East Indian islands, from where they branched out into the Pacific, gathering in as they traveled some of the habits and sounds of the races they displaced.

Much as we admire the geniality of the Hawaiians, and their poetic natures, it is prophesied by those who have interested themselves in a study of the race that it is doomed to extinction. Where the red man meets the white the former succumbs, either through the diseases acquired from the latter or from their vicious habits, which the red man adopts so quickly. Their language will probably outlive the race, having been adopted as a medium of conversation between the inhabitants of Asia and the Anglo-Saxons who meet in Hawaii on common ground. 


\section{CHAPTER XLI}

THE EDUCATION OF CHILDREN IN THE HAWAIIAN ISLANDS-AN

ORIGINAL PERPLEXING QUESTION WELL SOLVED.*

$\mathrm{S}$ the years rolled on, Breed's family increased, and he
and his wife began to experience the difficulties of
raising children in a country where educational facilities were comparatively limited. They employed a governess and erected a little school house, to which a few of the neighbors were allowed to send their children. The mother was extremely solicitous that her children should not associate with the natives for several reasons. A people so lately removed from barbarism naturally were too free in their language, and did not hesitate to speak of matters pertaining to the privacies of domestic life which are never uttered by an older civilization, except perhaps to the family physician. For this reason they. were desirous that the little ones should not acquire a knowledge of the Hawaiian language. They were compelled to have some native servants, as the men in charge of the cattle, horses, dairy, house-yard, etc., and it was a continual care to the mother to guard her little ones from the contaminating influences which surrounded them.

* The year 1910 shows Hawaii advanced in educational work to a point that has elicited unstinted praise from many prominent visitors. The public schools have kept mareh with the people, and no rural community is so small that it has no publie school, so few as a half dozen children being sometimes found in these out-lying school houses. In Honolulu are many grand public school buildings, that would do eredit to any eity in the Union. The public schools include the Lahainaluna School for boys, on Maui (formerly a missionary school), and the new College of Hawaii, a high-grade school for both sexes, teaching scientific agriculture and the mechanic arts, and maintained jointly by federal and territorial appropriations.

The private schools, too, are numerous and of high grade. The most prominent are the Kamehameha Schools for both boys and girls, Oahu College, the Mid-Pacific Institute (into which is incorporated the Mills Institute for boys, and the Kawaiahao Seminary for girls, and departments for Koreans, Japanese and Chinese), St. Louis College, Iolani School for boys, St. Andrew's Priory for girls, Aliiolani College for boys, Convent of the Sacred Heart for girls, Hilo Boys' Boarding School, Maunaolu Seminary for girls, and the Koloa Seminary for girls. There are also more than a few select private schools. 
Many of the missionaries had experienced this difficulty, and had striven to prevent their children from learning the native language. It is rarely that a native could be found who did not delight in using expressions which had a double entendre, and their actions and gestures in conversation were more or less rude and suggestive. Some parents amongst the foreign population were not so particular in guarding their children from these contaminations as Mrs. Breed. Hence arose a delicate question of allowing their children the privilege of attending the little private school, which was the cause of some bickering in the society of the neighborhood.

As the children of the missionaries had grown up and were in need of a higher education than the mother could give them, they had established a school in the vicinity of Honolulu, where they could be instructed in the advanced studies and have the comforts of home and its sacred influences. This was in 1841. This school was called Punahou, and in after years incorporated under the name of Oahu College. Here the missionaries endeavored to have their children instructed until they were prepared to matriculate in some of the colleges in the Eastern States.

After the establishment of Oahu College the school authorities were besought to allow children of other than missionaries to participate in the advantages of the college, and the same question arose as to the advisability of admitting children who had not been brought up with the same care that had surrounded those of the mission.

The missionaries were very indifferently paid, some receiving barely enough to supply their material wants, yet they struggled to support the college which was so essential to the future welfare of their children. Probably the extra tuition fees to be received induced the management to accept a limited number of children of residents of the Islands.

Punahou, as the alumni so dearly love to call it, was a success from its inception, and many of those who graduated there have made their mark in the world. Our hero, although a pedagogue in his youth, did not have time to devote to the supervision of the education of his children, consequently on Mamma's shoulders devolved this task. One after another, as the children arrived at an age when they could be carried no farther by the governess or tutor, they were sent to complete their education at Punahou. Breed had resolved that 
no child of his should go out into the world without an education, and that each of them should have a profession or a trade.

As they left home he gave them good advice, amongst which was to refrain from contracting evil habits. "I can not foresee," said he, "the company you will be likely to associate with, nor can I forewarn you as to the insidious manner in which such habits are acquired, but I can warn you against evil company. Should you contract irregular habits you may remember that by controlling your thoughts these can be overcome, and that although scarred by evil contaminations you can come back to that plane from which you have deviated."

The parents parted with their children with deep solicitude, but knowing that they had engrafted on their plastic minds principles of honesty, economy, industry and virtue, they let them go, feeling certain that their future was assured. The mother arranged with each of them to maintain a weekly correspondence, feeling that the contact thereby maintained would repay her tenfold.

In after years we find some of the sons, who elected to follow in the footsteps of their father, in charge of some of the sub-plantations making part of the estate. Others took degrees at Eastern colleges and in various ways made their mark in life. Several of the children intermarried with descendants of the missionaries and thus their lives became interwoven with that honorable body of men and women who, amidst great hardships had devoted their lives to the elevation of the Hawaiian. Singular to say, they, with the descendants of the missionaries, are dubbed as "missionaries," which in some minds is a term of reproach. Happy would the speaker be if he had as little to reproach himself with. On the occasion of the ordination of an English Bishop to the See of Honolulu, he was informed that "you are sent to the Sandwich Islands to preach the gospel to the heathen and the refuse of civilization who mingle with them." Probably this term of reproach, "missionary," originated with this "refuse of civilization," and is still used by them. A man who pays his debts and lives a moral life can stand being dubbed a "missionary," and many such would be proud if the title were true.

The Principal of Oahu College forwarded to Breed one of 
his son's compositions, writing that on seeing the caption he felt inclined to censure the boy, but on reading it carefully he thought it worthy of preservation. We take pleasure in inserting it in this history of our hero life's for the edification of our readers:

\section{"A CHINAMAN AND A MONGOOSE."}

A Chinaman in charge of a floodgate in the irrigation system on one of the plantations was undergoing the operation of having his head shaved at the hands of one of his colaborers. This they do every Sunday in this country; when they do it at home I do not know, as they have no Sundays in their land. I suppose the Chinamen think it queer to have to remain idle one day in seven. I know they are all the better for it.

While in the hands of the barber he saw a mongoose run into the room, and, breaking away from the barber, he closed the door with the intention of capturing the intruder. They had a lively time before they succeeded in covering it with a bucket. The room looked as if there had been "rough house" played in it by a well-drilled company. They were in as much dread of the mongoose as it was of them. Finally the Chinaman made friends with his captive and they became very intimate. One day the following conversation took place between them:

Chinaman-"You long-tailed animal, what did you want to come in here for?"

Mongoose-"Because I was hungry."

C.- "Don't you know there is a reward offered for your capture?"

M.- "Why do you call me long-tail? your tail is longer than mine."

C.- "That is so; but mine is a badge of servitude, which my people are compelled to wear since our country was conquered by the Manchus."

M.- "Mine is a natural appendage and very useful. You say there is a reward offered for my capture; do you not know that the Legislature, while passing the law, neglected to appropriate any money to pay the reward?"

C.- "No. I did not know that; I thought they were wise men and did everything right." 
M. - "Don't you know that there is a reward in the form of a large fee, for the capture of every long-tailed Chinaman illegally in the country?'

C.-."Yes, I know that; but I came here by invitation; how did you come into the country?"

M.- "I was brought here by a big fat man from Jamaica, for the purpose of killing off the rats."

C.- "Well, why do you not stick to that line of business?"

M.- "So I did until the rats became scarce, and I found it was easier to make a living by eating chickens and eggs, and also the eggs and young of pheasants and other birds which are fool enough to make their nests on the ground."

C.- "Well, they will exterminate you because you do not confine yourself to your business."

M.- "That's what they say about you. They will deport you, not because you do not stick to your business, but because you do work that other people cannot do and would not do if they could."

C.-."Well, this is a queer country; if you do what you are sent for they will deport you, and if you don't do what you were sent for, they will exterminate you."

M.- "Yes, but even if you are willing and the work is necessary to be done, they will neither do it themselves nor let others do it."

C.- "Then, indeed, we long-tails should be friends, as we are both hunted down by the man with the gun."

M.- "It is an unpleasant situation. If they had left me in my own country, I would have been better off."

C.- "I came here to better my condition, and now I find I am not wanted. I think I will go back and let them till their own land."

M.- "That reminds me of the mutiny on the ship. All wanted to be officers, and when they got into the boat to go ashore each one sang out, 'Pull away!' but the boat did not move, and all were likely to be dashed onto the rocks."

So the Chinaman and the Mongoose clasped tails, and swore eternal friendship; but the Chinaman lived in hopes that the Legislature would appropriate the money for the reward, and the Mongoose lived in hope of getting into the Chinaman's chicken coop.

George W. Breed. 
Oahu College during the past sixty years has grown very much, and some of the older alumni cannot recognize the institution, as only one of the original buildings now remains. Many of its graduates have kindly remembered alma mater and endowed it, while other parties, who appreciated its usefulness, have donated funds for the erection of buildings which gradually encroach on the campus where so many of the youth of the Islands have passed so many happy days. The original site was granted by a chief, and from the unused part of the grant much land has been sold for building sites and the funds invested for an income for the institution.*

* June 25-26, 1891, Oahu College celebrated the 50th anniversary of its founding. On that occasion Professor W. D. Alexander, the historian, delivered an address from which the following interesting notes are taken:

"The site which was chosen for it (Oahu College) is not without historical associations. It has been observed that springs- the 'eyes' of the land, as the Hebrews called them-have often been the haunts of the Muses, and centres of rising civilization. And we may even venture to hope that not even the spring of Castalia nor that of Vaucluse will, in future ages, be more illustrious than that of Punahou; and that this last may prove to be what its name signifies, a 'new spring' of knowledge and pure religion.

"The ancient legend concerning it was thus told to the writer by the venerable Kauhi and his wife, Martha Pohopu, some thirty years ago. Long ago an aged couple were living near the present spring. It was a time of drought and famine, when the people were obliged to search the mountains for ti-root and wild yams for food, and to trudge to Kamoiliili to fill their calabashes with drinking water. The outer spring seems to have dried up. One night the old lady dreamed that a man appeared to her, to whom she complained bitterly about her having to go so far for water, upon which he said: 'He wai no'(there is water)-and told her that beneath the stump of an old pandanus tree near by there was water. She awoke her husband and told him the dream, but he made light of it. The next night he had a similar dream. The apparition directed him to go to the sea and eatch some red fish, to roast them in ti-leaves, reserving a part as an offering to the family deities, and then to pull up the old tree by the roots. He awoke, and lo! it was a dream. But the impression it made on him was so strong that, in the morning, he hastened to carry out the directions that he had received, and when at last he pulled up the tree, water oozed out from beneath it roots. He dug out the place, and thus was formed the inner spring. A fish-pond was formed below the spring, and a dozen or more taro-patches irrigated from it.

"After the conquest of Oahu by Kamehameha I in 1795, he gave Moanalua, Kapunahou and other lands to Kameeiamoku, one of the four great chiefs who had raised him to the throne, and who had aided him 
Education has been promoted in all parts of the Islands, and there is no small valley where people live which does not have its school house. In centers like Honolulu and Hilo, the school buildings stand out prominently, light houses, as it were, to show the respect for enlightenment by both native and foreign residents. In early days the Board of Education had the foresight to obtain patents for lands for school houses in every district, as well as title to some lands which might produce rentals for the support of education. It would have

in all his wars. The chief was notorious for having eaptured the little schooner Fair American and having massacred the crew with the exception of Isaac Davis, in revenge for an outrage committed by Capt. Metcalf, of the Eleanor, some months before. Kameeiamoku died at Lahaina in 1802, and his lands descended to his son Hoapili, the most intimate friend of Kamehameha $I$., who afterwards became Governor of Maui. Hoapili resided several years at Punahou, near the spring, and during the Conqueror's second residence on Oahu, from 1804 to 1811 , he also and his wives frequently visited this charming retreat. Hoapili gave Punahou to his daughter Liliha, who married Governor Boki, and after their return from England in the Blonde in 1825, they frequently resided here.

"In December, 1829, just before starting on his fatal sandalwood expedition, Boki gave Punahou to Rev. H. Bingham, with the approval of the Queen-Regent, Kaahumanu.

"In 1831 Kaahumanu caused a stone wall to be built, extending from Punchbowl Hill, across Punahou, nearly to Moiliili, in order to protect the cultivated lands above it from the cattle and horses grazing on the Kulaokahuna Plain. Part of this old wall still exists between Punahou and Piikoi streets. A large rock was placed on each side of the Manoa road by Governor Kuakini, to form a gateway, of which the smaller rock on the Erra side still remains. The larger rock on the other side, about ten feet in height and weighing several tons, in spite of its historical associations, was broken in pieces, about 1857 , and used in build. ing the wall enclosing the old 'lower pasture.' The story of the moving of this rock, as told by Dr. Judd, is as follows:

"When Kuakini, alias Gorernor Adams, had called out the people of this district to build the mall, he assigned the section adjoining Punahou to the 'Hulumanu,' or body-guard of the young King, Kamehameha III. The 'big rock' was then exhumed from its bed (on the West side of the road leading to Manoa Valley, opposite the old 'Cow Pen'), and rolled upon a frame-trork of ship's spars. The young King then seated himself unon the apex of the rock, and gave the word of command, when rock, King and all were lifted upon the shoulders of the Hulumanus-numerous as ants tugging at a kernel of corn-and earried down to its place.'

"The advantages of Punahou as a site for a boarding-school were observed as early as 1831, for in that year the Rev. Reuben Tinker, while riding past, remarked to Dr. Baldwin, his companion, 'that, sir, is the 
been well if the natives could have been taught English from the beginning, on account of the facility of obtaining books in that language, but there were not sufficient teachers. The number of books translated into the vernacular is very limited, and the education of the native is therefore very circumscribed, although almost all can read and write, while many of them are very fair English scholars.

site of the future college.' And long before Mr. Bingham's return to the United States in August, 1840, he had offered the land for this purpose.

"In 1831, Mr. Bingham built the 'old house' of adobe, behind the site of the President's house (near a clump of hau trees), where it stood for over thirty years. To this cool and quiet retreat he often retired from the heat and noise of the plain.

"The land lying between the taro patehes and the gate was planted with sugar cane in those days, and the famous 'bathing pond' (afterwards enlarged by Mr. Rice), was first excavated to serve as a storage reservoir for the purpose of irrigation.

"The wall along Punahou street was built in 1836 under the direction of Mr. E. O. Hall, assisted by Mr. H. Dimond, while the remainder of the enclosure was completed by the natives, under Mrs. Bingham's supervision.

"The need of a school for their children had long been felt by the missionaries, who were themselves men of liberal education, and no hardship of their lot was so keenly felt as the heart-breaking separation from their children, sent away from loving bomes at a tender age, to a distant land for their education." * * * 


\section{CHAPTER XLII}

RELIGION OF THE EARLY HAWAIIANS AND WHY THE PEOPLE

WERE READY TO RECEIVE CHRISTIANITY-EVIDENCES

OF EARLY CIVILIZATION.

$\mathrm{S}^{\mathrm{a}}$

OMEWHAT has been written of the sports, the superstitions, the language, the innate hospitality, the knowledge of the sciences and arts prior to the advent of the foreigner; and it might be well to say something of the religion or religious belief of the people. No new land has ever been discovered wherein the aborigines did not have some religious belief-sometimes, as in the case of the Australians, of a very low or indistinct, indefinite type. The Hawaiians, on the contrary, were a people very much addicted to worshiping gods, and amongst them were those to whom were attributed powers greater than others. Like a majority of the human race, it was easier to believe and worship when the god or a representative of him was tangible. It may be that the very lowest of them believed that the carved image had power in itself to bless or blast them, but the masses did not so believe; they worshiped the invisible through the visible type. There was hardly a branch of domestic economy into which the gods did not take part, or in which the aid of a particular god was not solicited. In fishing, in husbandry, in the arts, in the household, particular incantations were made by kahunas, soliciting the success of the undertaking. Naturally a field so replete with superstition was a garden for the strong-minded kahunas, who worked on the credulity of the masses, both for their own benefit and to maintain the power of the chiefs. This, however, is merely a repetition of what history tells us has been the case with all the races of the world.

Amongst a people so circumscribed and isolated, and whose increasing numbers threatened to overpopulate a land as limited as Hawaii, it was necessary to make provision for sustaining life. The sea being replete with food fishes and 
algæ, the Hawaiians became adept fishermen, using many means to capture the denizens of the deep.

In places on the coasts where the shallows ran far out and in inlets of the sea, walls were built and ponds constructed which permitted the ingress of fish and at the same time automatically prevented the egress, large traps as it were. These afforded breeding places and a convenient receptacle from which they could draw at any time. The tabu was effective to prevent the catching of certain fish at times in the year when they were known to spawn. They regularly fed certain fish with squash and other food to entice them to return periodically to the same place.

Their ingenuity in making canoes and fishnets, some of the latter of great dimensions, has been mentioned. In making fish hooks from the limited material of bone, shell, and hard woods they exhibited no mean skill. They studied the habits and habitats of fish, and their skill in taking and preserving them both by drying and salting was remarkable.

Their familiarity with the sea and its inhabitants was universal, it being rare that a native could be found who was not an expert swimmer, many of them being able to remain under water for a long time. They had no fear of any of its denizens and would attack a man-eating shark with the aid of a stick sharpened at both ends and kill it. Their knowledge of the algæ or seaweed was very extensive, many kinds of which were edible, and others used for medicinal purposes.

In agriculture they excelled and were observant of the seasons. They assisted nature in carrying pollen from flower to flower and thereby produced superior species which were assiduously cultivated. They recognized the value of a change in diet and of places of residence for recuperation. They would abandon a diet of taro, for breadfruit or for that of sweet potatoes for the well-known effect on the system. In fact, in so many hundreds of ways were they superior to what the discoverer thought them to be, that the early Hawaiians might be termed a civilized race. 


\section{CHAPTER XLIII}

DEBASEMENT AND DECIMATION OF HAWAIIANS DUE TO IVHITE REFUSE OF CIVILIZATION WHO PRECEDED MISSIONARIES.

$W^{1}$ HEN the first missionaries arrived at the Islands, they were by no means the first white men to settle here; in fact, there was quite a colony scattered throughout the group.

These men were almost all sailors, who had deserted from merchant vessels, although some were from national vessels. None of them were officers or of the educated classes. It was often said that "when a man rounds Cape Horn he leaves conscience behind," and this was true of nearly all of those who settled on the Islands of the Pacific in very early days. There were some few exceptions.

The number of these sailors was continually augmented by arriving vessels, each of which left some behind, and generally the worst men in the crew or ones whom the officers were glad to be rid of.

Many of this white refuse of civilization came up from Australia, from whence they were escaped "lags," or, having learned all the vices of the "lags," were allowed to leave for their country's good.

Others came from Hongkong in the early trading vessels, which was not much to boast of. The very Hawaiian word for Chinaman is a standing monument to the licentiousness and bestiality of that free port.

When a white man falls, he sinks deeper into crime and licentiousness than the barbarians amongst whom he has settled. This is doubly unfortunate, as from their intelligence and skill with tooIs they are naturally looked up to by their barbarian hosts and their example has a most pernicious influence.

They found a people who, with few exceptions, were monogamous in their home life, but they paid no respect to the families of natives and broke into them most ruthlessly. All 
the world over primitive people make some form of intoxcating drink, and the Hawaiian wãs no exception. Theirs, however, went no farther than the fermenting of starchy foods, like sweet potatoes, taro, ti root, etc., and making a narcotic drink from the root of awa or piper methysticum.

The runaway sailor taught them to distil these fermentations and make alcohol. The knowledge of this art quickly spread through the group, the name of the liquor "okole-hao" from its having been made through the use of a musket barrel for condensing the steam, being still the name for this, now surreptitiously made, fire-water.

It might be said that drunkenness was universal, so quickly did the natives take to it and so widespread was its use.

Having thus debased the aborigine with alcohol, disrupted and corrupted his family and dragged him to a lower level than in his barbarism he had ever dreamed of, these white men were naturally the first to resent the moral teachings of the missionaries.

They endeavored to enlist the natives against them and on more than one occasion personally led the lower element in attempts to destroy the homes of and kill the missionaries. Also by assertions and innuendo they endeavored to render nugatory their precepts and teachings.

They manufactured a word for hypocrite, "mikinari," which was applied to those who followed the teachings of the missionaries, as the term Christian was, in derogation, applied to the followers of Christ.

The immorality inculcated by this refuse of civilization was extremely difficult to eradicate, and added tenfold to the labors of the missionaries.

The debasement and decimation of the Hawaiian is due almost wholly to this refuse of civilization and their progeny.

The sterling qualities of the early missionaries and the examples of their moral lives could not be decried, however, and the natives generally learned to love and respect them.

The sons of missionaries, with some noble exceptions, did not follow in the footsteps of their fathers and become teachers of the gospel; but the mass of them would form a community much above the average of any of a similar size in the United States in education and morality.

I have said elsewhere that the epithet "missionary" was an opprobium applied by a certain class when speaking deroga- 
tively of any one. The reader will now understand the origin and meaning of the epithet, and comprehend the standing of the speaker or one applying the term.

Later coming foreigners mingling with the progeny of the "refuse" find the term come trippingly on the tongue, and we even read in the writings of an alleged learned Doctor that the "missionaries introduced gin among the Hawaiians." It merely exhibits the character of his associates here while learning somewhat of the history of the decimation of the natives. 


\section{CHAPTER XLIV}

LIFE IN HAWAII AND WHAT IT STANDS FOR TO PEOPLE WHO CALL THE ISLANDS "HOME."

C OME one has said that "the bronze statue of Kameha$\int$ meha the Great, which ornaments the grounds of the Judiciary Building, in Honolulu, is typical of a trait of the Hawaiian people in welcoming those of other lands." To those who call Hawaii their home and to those who have visited the Islands there is as much truth as poetry in the expression. Standing with his right arm extended, palm upwards, he welcomes all the world. In his left hand he holds a spear, suggestive of protection. From the discovery of the group, in 1778, the reputation of the natives for gentleness and hospitality has been maintained. The unfortunate killing of Captain Cook by the natives should not be wholly chargeable to them, as there was some "contributory negligence" on his part that is not set down in the geographies of our school-boy days, which not only recite part of the story, but add to it that "his body was eaten."

One of the very ancient traditions amongst the Hawaiians was that a Messiah, "Lono," would in due time come back to the Islands and in grander form than that of his departure. So that when the immense vessels (called by the natives "moku," islands) hove in sight and an English captain arrayed in brilliant uniform stepped ashore it is not surprising that they worshiped him, as they did. The surprise is that he permitted it, for, having made considerable stay at New Zealand and Tahiti, where the language is very similar to the Hawaiian, as well as the worship of idols, he not only was capable of talking with them, but permitted them to offer sacrifices to him for some ulterior purpose. One must be very clever who would sustain the reputation of being a god. But he was not, and his death was not wholly due to the treachery of the natives. The long stay of his vessels and the lavish hospitality showered on him and his men by the 
chiefs had become very burdensome on the people, as the foodstuffs had to be carried great distances, over the most rugged roads in the world, to the port where his ships lay sheltered at anchor, and it took very little to snap the cord of reverence and friendship which existed. The Captain, following a course he had successfully adopted in the South Seas, unwittingly took the step and paid the penalty. In no land are the rulers more revered than in Hawaii, and when Captain Cook endeavored to coerce the king into going on board his ship, intending to hold him as a hostage for the recovery of a boat which was stolen, he was hustled and hit with a stone, at which he groaned, thus dissipating the belief that he was a god.

When the great King, Kamehameha, came into power, he yearned to have a "haole," (foreigner) of his.own, and when opportunity offered he cut off John Young from a visiting crew and detained him, 1790. When he saw the anxiety of Mr. Young to return to his own people, Kamehameha did all in his power to assuage his grief at the separation. He gave him a beautiful wife of high lineage, a large retinue, some of his choicest lands, and treated him in the most hospitable manner. Fortunately the king had found a good man, one whose counsel was wise, and in whom he placed the most implicit confidence.

Whether his advice was to be kind to strangers, or more than likely hospitality was an inherent trait in Hawaiian character, foreigners have always been made welcome. So it was on the arrival of the first company of American missionaries in 1820, the chiefs made them as comfortable as their means would permit.

In preparing to write on "Life in Hawaii," the idea was formed of showing in many ways how this admitted hospitality of the aborigines extended in society, commerce, climate, and even the very soil yielded up its wealth to the educated, trained agriculturist from foreign lands. And also how the feeling engendered in the recipients of the kindness of the natives a reciprocal feeling of love and respect for them.

As one leaves the chilly and fog-bound coast of California bound for Hawaii he soon begins to realize a change in the weather and the heavy wraps are laid aside. The sky assumes a bluer tinge, the sea becomes smoother, the trade winds waft the royager towards his goal, and, perchance, if 
at the proper season of the year, the Southern Cross is seen in the heavens. The everchanging sea has its charms, and perhaps schools of flying fish or porpoise engage his attention, while the brilliancy of the sunrise lures him from his couch, and the phosphorescent sea will tempt him to watching it to late hours. One morning the Islands will spring into view, and from that time until he leaves them, be it ever so long, life will take on new charms.

The trade winds, which blow nine months in the year, carry moisture sufficient to furnish a mantle of green to the serrated ranges of mountains on each island. As the voyager sails along the coast the ever-changing scenery engages his attention. The first view which the northerner obtains of the tropics is pleasing and lasting. It would appear that the shores were fringed with palms, while other rioting wealth of verdure extends to the crests of the mountains.

If the coast of Oahu, on which Honolulu is situated, is first sighted, he will notice the peculiarly shaped headlands of Mokapu, Makapuu, and Diamond Head, all of them ancient extinct craters. Rounding the latter, the city of Honolulu springs into view, a city embowered in foliage. A few high buildings are seen, but the inhabitants love to dwell in cottages, cottages with verandas of wide dimensions, where they pass so much of their lives. The city's watering resort, Waikiki, with its cozy hotels, is passed as he makes his way to the entrance to the harbor. Then he sees the bronze-skinned, laughing faces of the boatboys who bring the pilot on board, and is agreeably impressed. Arrived at the wharf, he thinks half of the city has turned out to welcome him, as the arrival of steamers will never cease to be a novelty to the people of Honolulı. He finds himself bound for one of the comfortable hotels in an auto, hack or the street cars, and except for the tropical surroundings would be unaware that he had left the mainland.

The word "aloha" (welcome) is on every lip, and as he becomes better acquainted he will find that this is not superficial. While the natives, from ancient times, always welcomed the alien, they also acquiesced in their innovations and adopted such as were pleasing.

He will rarely see a tree, shrub or vine on the lowlands which was not introduced by the foreigner. While the natural shrubbery was beautiful, still those who had circumnarigated 
the globe knew of rare and charming trees, shrubs and vines in other parts of the tropical world and sought to introduce them into the land they had learned to love. As a consequence we find the macadamized roads lined with hedges of many varieties, and rare ornamental trees and vines embellishing well-kept grounds on every hand. By the way, this keeping up of grounds in the tropics requires much work, as the growth is so luxuriant that the lawns must be frequently mowed and the falling leaves require daily removal.

In place of the thatched hut which housed the aboriginal inhabitant, the native has adopted the frame buildings of the foreigner. Also he has furnished it throughout with furniture and bric-a-brac from across the ocean. In adopting the house and furniture of the alien he also largely adopted his manner of living so far as he believed it was an improvement on that which maintained amongst his forefathers.

The earliest writer who describes the natives speaks of the universal custom of both sexes of wearing wreaths of flowers, ferns or vines. In this respect they differed from the Polynesians of the South Seas, who disfigured their ears, noses and lips by piercing them and inserting ornaments (?) of bone, shell or wood. This pretty custom of wreath-wearing was reciprocally adopted by the foreigner, and those who are to the manor born or who have lived long in the country do not consider it bad taste to wear a "lei" or wreath.

There may be some exceptions, but the courtesy and politeness of the Hawaiians is proverbial, and their geniality is contagions. They appear to take little forethought for the morrow, and do not enter the race for the almighty dollar to the exclusion of enjoyment of the present, as is the custom of the outside world. Who will say they are not as well off when the silver thread breaks as they who have maintained a continuous struggle to the last to acquire "filthy lucre?"

They are fond of good clothes, the women especially always appearing well dressed. They have adopted a custom or fashion which warranted comfort, and in this have been largely followed by foreign ladies.* In their manner of living

* No doubt the holoku, a dress similar to the well-known "Mother Hubbard" of the mainland, is here referred to. This dress, however, is not an invention of the Hawaiians, but was introduced by the first missionary "mothers," who made the first dresses of the kind for some of the Hawaiian women of rank, and then taught them and other Hawaiians, how to make the garment for themselves, and to do other needlework. 
they adopted a happy medium between the extreme punctiliousness of the alien and the crudeness of the aborigine. Their staff of life, instead of bread, is "poi," a dish made either from mashed taro, sweet potatoes or breadfruit, and the old residents and foreigners born on the soil have learned to like it.

In earlier days society was much more mixed than at present, and many felicitous marriages took place between the two races. It wotld appear that in the blending of the two races there has been a certain reciprocity maintaining through which they have approached each other closer than a stranger would expect. From expressions made by them it is noticeable that others than Anglo-Saxons are not considered their social equals. Marriages have occurred between Hawaiians and others than whites, but as a rule these are deprecated. While respecting the learning of the Anglo-Saxon and probably his manner of living, the native has always felt himself the social equal of any.

I have spoken of their innate hospitality and of their custom of entertaining strangers, and must admit they have not always entertained "angels unaware," but have been sadly deceived.

To the visitor, the numerous races met on the streets is always a source of interest. The native has long been outnumbered by the Japanese and Chinese, who have supplanted him in many walks in life. The Japanese apes the foreigner in dress, whilst the Chinese adheres largely to the fashions of Cathay. It is not an uncommon occurrence to see Orientals using the native language as a medium of conversation. The Chinaman is the gardener of the Islands and supplies all the vegetables found in the markets, or rather which he brings to the door of the consumer. Also he has supplanted the native in preparing poi, the Hawaiian staff of life. The Japanese, on the other hand, has supplanted the native in his calling as fisherman, at which the Hawaiian was an adept. Coming from lands where horses were by no means common, we find these Orientals driving and owning hacks and wagons and even automobiles. The Chinese do all the washing for both whites and natives, and it is a very common occurrence to see them delivering the laundered clothes in hacks which have probably outlived their day.

Perhaps of all places of interest to the student of humanity 
is the public schools, out of which pour hundreds of children of every shade of color and of many nationalities. All are learning English, and frequently the Chinese excel on account of their intense application as students. They enter the athletic sports together, talk English, perhaps brokenly, and are becoming Americanized. Thoughtful tourists, seeing the wonderfully cosmopolitan population, wonder what will be the nature of that which will maintain on the Islands in the future. It certainly will be a blending of the occident and orient.

With one or two great exceptions the natives own very little land and are almost all dependent on their daily earnings. The cause of this peculiarity lies in the fact that at the time of the great division of lands in 1847-8 the common people were awarded such small pieces as they or their parents proved up as having been cultivated or resided on by them. The chiefs, on the contrary, were awarded large divisions (excepting the rights or kuleanas of the common people within the borders thereof). Most of the small pieces were adequate for their support prior to their acquirement of artificial wants, learned from the foreigner, but afterwards almost valueless. As nearly all of the lands of the people were taro lands or house-lots, and these were adapted to the cultivation of sugar, they were gradually sold to sugar companies and their owners reduced to plantation laborers or have dropped into the metropolis in search of day labor.

The chiefs, unaccustomed to providing for themselves, gradually disposed of their lands to foreigners, and have become almost extinct. From the well-known character of the natives it is believed that should the remaining government lands be divided amongst them, or should each of the present generation be granted tracts of land, another generation would witness the foreigner in possession of those likewise. Had the land been granted to them in the first instance with a clause prohibiting alienation, they would have leased them or abandoned them on account of their inability to support them for the cause above stated. Free hospitality and their innate generosity unfit them to compete with those of other countries who pursue the almighty dollar to the exclusion of present enjoyment.

Although we do not find that architecture in Hawaii reached the stage which it did in Babylon, still, in spite of 
the limited means, lack of metals, etc., their dwellings were models of neatness and comfort. Some of their irrigating ditches and mountain roads were laid out as skilfully as if done by a modern civil engineer. The chiefs, having unlimited control of the people, compelled them to labor and preserve the banks of streams so that the water might not devastate large tracts. This was sometimes a severe tax on the people, as the necessary stone for embankments might be at great distances and had to be carried or passed from hand to hand, requiring all the available labor in the district. They had no means of breaking up rock and were compelled to use only what was portable.

This building of embankments against the furious tropical freshets involved frequent renewals, and only by the feudal manner of government could it have been maintained.

After the advent of the foreigner and the chiefs lost control of the people, many of these embankments were allowed to dilapidate and much of the anciently cultivated land was overflowed with rocks and debris carried down by the freshets.

Signs of cultivation or residence in remote parts of the islands, in the form of stone enclosures, either used for pens for pigs or the walls of houses, still remain to attest to the dense population which once filled the land. Also embankments of water courses, now covered with alluvion and grown over with wild vines and shrubbery, show to what extremes the native was compelled to go to conserve the lifegiving water.

It is curious that from water, the fluid which is so abundant and never resting until it finds its level, touching alike the rich and the poor, the great and the humble, should come the Hawaiian word for law. It probably arose from the commands of the chief allowing to each division of land its proper share, either in time of flowing or in quantity. From those early divisions, a knowledge of which was transmitted from father to son, men became imbued with a sense of possessing rights which none could trample on with impunity, and in regard to water rights as well as in ownership of any other tangible or intangible affairs, men were ready to defend them against the aggressor.

The innate selfishness of mankind provoked war amongst the Hawaiians as it is doing among nations the world round. Those internecine wars may have been useful as factors in 
political economy, by reducing the superfluous population, or causing the survival of the fittest.

By some means the ancient people arose from a very low estate, denominated by them "po" or night, to the state of civilization they were enjoying at the time of the advent of the white man, and were ready to receive and appreciate the teachings of the gospel. A more fruitful soil for the planting of Christianity was found nowhere on the face of the globe, and probably if it had not been that at the same time some of the same white men planted tares which choked the growth of the high teachings of the missionaries, the Hawaiians would have continued to multiply, and the land would today be filled with a race whose natural characteristics denoted their superiority.

Hawaii, its geography, history, ethnography, philology, botany, and manners, customs and habits of its people, affords an inexhaustible theme for the writer, and one, too, which will have an increasing interest to readers throughout the civilized world. 


\section{CHAPTER XLV}

METAL BEING UNKNOWN TO THE ANCIENT HAWAIIANS, THE ART OF WEAVING ENTERED INTO THEIR EVERY UTILITY.

$\mathrm{T}$

HE ancient Hawaiians belonged to that class of Polynesians which may be called tapa-beaters in contradistinction to weavers, yet the infinitude of uses to which they applied fibrous materials must be considered under the head of weaving. For some occult reason the knowledge of the loom was not brought with them in their migrations from the south or earlier still from India, Persia, Egypt and Syria, whence the study of philology shows them to have originated. In New Zealand we find the natives using the loom for spinning the flax of the country, and their traditions show that they were descended from the Hawaiians. It is more than likely that the loom came in at a later date with a migration from the northwest, which also brought with it a defined change in the language of the New Zealanders.

Weaving covers the minor arts of platting, braiding and netting, and combined we will see they were of prime importance to a people to whom metals were unknown.

The very home of the Hawaiian was a complete conception of the weaving art; apart from the posts of the house, which were embedded in the ground, the whole was woven together with twisted cords of fibrous materials of which the tropical forest afforded an abundance. The plates (lohelau) were fastened to the posts (pou), the rafters (o'a) to the plates, and the battens (aho) to the posts and rafters by these same fibrous materials.

In the better houses the lining was made of dried, smooth banana stalks, rushes or cane leaves woven on to the battens in a very neat manner. Then the work of thatching was begun, which consisted in weaving on the pili grass, which rendered the whole impervious to the elements. Frequently the corners, hips and ridge were bonneted with the durable amaumau fern, which, through its brown color, gave an ar- 
tistic effect to the structure. The lintels and sides of the doors or other openings were platted to better resist the wind and which also added to their neatness and durability.

The earthen floors were covered with mats platted from the leaves of the hala or pandanus, which to the Hawaiians was one of the most useful trees of the forest. Not only were the floors covered, but piles of these mats made the beds of both chiefs and commoners, the former frequently using as many as sixty layers, the upper ten of which being of the finest quality and covered with a counterpane woven from a fine rush called makaloa. These makaloa mats were frequently ornamented (pawehe) with an inwrought pattern of maiden hair fern stalks. The Hawaiians were not much given to ormamentation in matmaking, although frequently their crumb-cloths were platted with serrated edges.

In and about the courts of some chiefs the grounds between the main and outhouses were at times covered with mats made of green lauhala of the natural width.

The sails for canoes were platted from the young leaves of the pandanus, which were much more pliable than the older ones.

All the labor of collecting the leaves devolved on the women, and many good housewives kept rolls of these in store against such time as they were wanted. The men did all the collecting of pili grass, etc., for house building and attended to the agricultural work and fishing,

Among the ancient Hawaiians the art of weaving was employed more in the making of domestic utensils and housefurnishings than of clothing, as the latter was made from the felted bark of the paper-mulberry (wauke) and several other plants and trees. The most important utensils were baskets and containers, of which they had many forms and which were adapted to a great variety of uses. Baskets used as containers were generally braided of lauhala and were more closely woven than fish-traps. Tough, wiry fern growths. or the ieie were generally used in making the latter, some of which were of giant proportions and funnel-shaped.

The fiber of the olona was much prized by the natives and was the material from which all their fish lines and nets were made. Some of the latter were of mammoth size, twenty fathoms in length by two in depth, floats of carved wiliwili (Hawaiian cork), and sinkers of carved stone being 
attached. The labor of making these involved months of application. The work of spinning or twisting this fiber, which was done by rolling or twisting it on the thigh, devolved on the women, and was one of the arts taught from childhood.

In an instlar country like Hawaii the inhabitants were much dependent on the sea and its fauna and flora for a livelihood, and they became adept fishermen. Their baskets for collecting the edible sea-weeds, of which they were acquainted with a great variety, were numerous and woven of many materials.

I have said that but little use was made of the weaver's art for the making of clothing. To this there is an exception, as all the females wore pa-us made of woven leaves, probably an heirloom from Mother Eve. Also the helmets and feather cloaks of the chiefs were made by weaving the feathers of the oo, mamo, and iiwi into a netted base of twisted olona fiber, forming a perfectly smooth surface. This was the acme of the weaver's art and the infinitude of labor in collecting the material and completing the garment caused these articles to be very highly prized. Peatutiful wreaths (leis) were also made of these bright-colored rare feathers, and with amulets and necklaces of shells were the sole ornaments to which the women were addicted.

The only footwear of the Hawaiians were sandals woven of tough grass and leaves, at the making of which they were very adept. In a volcanic country, especially in the regions of aa flows, the necessity for them was apparent. I have been told that after horses began to multiply it was not unusual to see the roads over some of those flows thatched for miles to protect their unshod feet.

Necessity is the mother of invention, and probably the absence of metals compelled the use of the plethora of fibrous materials which the forests afforded. Their stone axes, made of flint or some of the better volcanic rocks, were bound to the handles by tough cords, and there were many forms of slings for carrying heavy weights. An army was always accompanied with a body of men carrying the food supplies, which they did by means of sticks (mamaka) carried on the shoulders. One of the objections to Captain Cook was the great hardship his long stay at Kealakekta imposed on these burden-bearers, who had to carry all the foodstuffs from Waipio and Hamakua, nearly a hundred miles, much of it across aa flows. 


\section{CHAPTER XLVI}

A BRIEF HISTORY OF THE SUGAR INDUSTRY OF THE HAWAIIAN ISLANDS-SUGAR CANE INDIGENOUS TO THE SOIL.

$7 \mathrm{HE}$ author believes that a brief history of the sugar industry on the Hawaiian Islands would be of interest to the reader, and although he dislikes statistics, the exports are quoted, as they show at a glance the steady growth from zero to the immense proportions they have reached at the present writing.

Sugar cane was indigenous to the islands, i. e., as far as traditions reach back, it had been one of the foodstuffs cultivated. It is said to have been brought from the South Seas with the earliest immigrations, although the natives of the Society Islands always have said that their best cane, vaihi, was brought from Hawaii. It is one of the grasses which grows continuously from the same root, tradition in one place reciting that it had been known to grow for a hundred years and gave promise of reproducing itself for another hundred.

The natives were always fond of it, and attribute their good teeth to its cleaning properties. It was one of the herbs administered by their kahunas or doctors in certain complaints. Long before an infant was old enough to masticate the stalk, mothers would crush it for them and feed them from mouth to mouth.

Enough credit has not been given to the aborigines of the islands for their knowledge of horticulture and agriculture by writers or the early missionaries, but the first white men who settled among them did observe that they recognized the difference in a number of kinds of taro, sweet potatoes and sugar canes, which to a casual observer would not be noticed.

Of course, until the white man came with his iron vessels, no use of sugar cane was made farther than as food and medicine. Of late years research has been made as to the earliest 
foreigners who attempted to make a marketable product of the juice of the cane.

Mr. L. L. Torbert, whom the author knew well, read a paper before the Royal Hawaiian Agricultural Society in 1852, in which he stated that the earliest sugar manufactured on the islands was in 1802 by a Chinaman, on the Island of Lanai, who came in one of the sandalwood trading vessels and who brought with him a stone mill and boilers; but having located at what proved to be a place indifferently supplied with water, his venture proved a failure. He returned, taking his apparatus with him. Mr. Torbert gave as his authority for this statement, John White, who was his fatherin-law, and who had landed on the islands in 1797, and who attached himself to Kamehameha I. and traveled over the group in his retinue. The author learned the same facts from another source, and read it also in an English magazine published in 1827.

Don Paulo Marin, who also arrived in the eighteenth century, and lived on the islands for a great many years, states that he made sugar in Honolulu in 1819. It is recorded that an Italian, Lavinia, made sugar in Honolulu in 1823, the cane for which was mashed by stone pestles on koa poi boards, the juice being boiled in copper kettles.

Antone Catalina, a Portuguese, made an excellent syrup at Waikapu, Maui, about the same time; and a Chinaman named Hing Tai also established a sugar mill at Wailuku, which mill, a crude stone affair, the author has often seen. An Englishman, John Williamson, began the cultivation of sugar on a large scale in 1825 , planting 100 acres in Manoa Valley, Oahu, but as he died in 1827, the cultivation was kept up for but one crop thereafter.

The first establishment, however, of sugar cultivation where the parties had ample means and could go into the business systematically, was at Koloa, Kauai, which plantation was begun in 1835. Upright modern rollers, probably home-made, were used, and the cane fed in by hand. The juice was boiled in open pots, and the product was very indifferent.

In several places on the islands small plantations were started with varying success; and probably the whole product was consumed at home, as no mention is made of any being exported until 1837. 
To show the mammoth proportions the industry has reached, the annual exports are guoted:

\begin{tabular}{|c|c|c|c|c|}
\hline Year & $\begin{array}{l}\text { Sugar } \\
\text { lbs. }\end{array}$ & $\begin{array}{c}\text { Molasses } \\
\text { gallons }\end{array}$ & Year & $\begin{array}{l}\text { Sugar } \\
\text { lbs. }\end{array}$ \\
\hline $1837 \ldots \ldots$ & 4,276 & 2,700 & $1874 \ldots \ldots$ & $24,556,611$ \\
\hline $1838 \ldots \ldots$ & 88,543 & 11,500 & 1875. & $25,080,182$ \\
\hline $1839 \ldots \ldots$ & 100,000 & 75,000 & $1876 \ldots \ldots$ & $26,072,429$ \\
\hline $1840 \ldots \ldots$ & 360,000 & 31,739 & $1877 \ldots \ldots$ & $25,575,965$ \\
\hline $1841 \ldots \ldots$ & 60,000 & 6,000 & $1878 \ldots \ldots$ & $38,431,458$ \\
\hline $1842 \ldots \ldots$ & & & $1879 \ldots \ldots$ & $49,020,972$ \\
\hline $1843 \ldots \ldots$ & $1,145,010$ & 64,320 & $1880 \ldots \ldots$ & $63,584,871$ \\
\hline $1844 \ldots \ldots$ & 513,684 & 27,026 & $1881 \ldots \ldots$ & $93,789,483$ \\
\hline $1845 \ldots \ldots$ & 302,114 & 19,353 & $1882 \ldots \ldots$ & $114,177,938$ \\
\hline $1846 \ldots \ldots$ & 300,000 & 16,000 & $1883 \ldots$ & $114,107,155$ \\
\hline $347 \ldots \ldots$ & 594,816 & 17,928 & 1884. & $142,654,923$ \\
\hline $848 \ldots .$. & 499,533 & 28,978 & $1885 \ldots \ldots$ & $171,350,314$ \\
\hline $849 \ldots \ldots$ & 653,820 & 41,235 & $1886 \ldots \ldots$ & $216,223,615$ \\
\hline $50 \ldots \ldots$ & 750,238 & 129,432 & $1887 \ldots \ldots$ & $212,763,647$ \\
\hline $1851 \ldots \ldots$ & 21,030 & 43,742 & $1888 \ldots$ & $235,883,346$ \\
\hline $1852 \ldots \ldots$ & 699,170 & 62,030 & 1889. & $242,165,835$ \\
\hline $53 \ldots \ldots$ & 642,746 & 75,769 & $1890 \ldots \ldots$ & $259,789,462$ \\
\hline $1854 \ldots \ldots$ & 575,777 & 68,372 & 1891. & $274,983,580$ \\
\hline $1855 \ldots \ldots$ & 289,908 & 38,304 & 1892. & $263,636,715$ \\
\hline $1856 \ldots \ldots$ & 554,805 & 58,842 & $1893 \ldots \ldots$ & $330,822,879$ \\
\hline $1857 \ldots \ldots$ & 700,556 & 48,486 & $1894 \ldots$ & $306,684,993$ \\
\hline $1858 \ldots \ldots$ & $1,204,061$ & 75,181 & $1895 \ldots \ldots$ & $294,784,819$ \\
\hline $1859 \ldots \ldots$ & $1,826,620$ & 87,512 & $1896 \ldots \ldots$ & $443,569,282$ \\
\hline $60 \ldots$ & $1,444,271$ & 108,613 & $1897 \ldots$ & $520,158,232$ \\
\hline $1861 \ldots \ldots$ & $2,562,498$ & 128,259 & $1898 \ldots \ldots$ & $444,963,036$ \\
\hline $2 \ldots$ & $3,005,603$ & 130,445 & $1899 \ldots \ldots$ & $545,370,537$ \\
\hline $63 \ldots$ & $5,292,121$ & 114,413 & $1900 \ldots \ldots$ & $344,531,173$ \\
\hline $1864 \ldots$ & $10,414,441$ & 340,436 & $1901 \ldots \ldots$ & $690,822,132$ \\
\hline 8 & $15.318,497$ & 542,819 & $1902 \ldots$ & $720,553,357$ \\
\hline 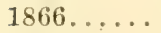 & $17,729,161$ & 851,795 & $1903 \ldots \ldots$ & $774,825,420$ \\
\hline $1867 \ldots$ & $17,127,187$ & 544,994 & $1904 \ldots \ldots$ & $736,491,992$ \\
\hline 3.. & $18,312,926$ & 492,839 & $1905 \ldots$ & $832,721,637$ \\
\hline 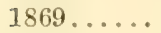 & $18,302,110$ & 338,311 & $1906 \ldots$ & $746,602,637$ \\
\hline $70 .$. & $18,783,639$ & 216,662 & $1907 \ldots \ldots$ & $822,014,811$ \\
\hline$\cdots$ & $21,760,773$ & 271,291 & 1908. & $1,077,570,637$ \\
\hline & $16,995,402$ & 192,105 & $1909 \ldots$ & $1,022,863,927$ \\
\hline & $23,129,101$ & 146,459 & & \\
\hline
\end{tabular}

Molasses gallons 90,060 93,722 130,073 151,462 93,136 87,475 198,355 263,587 221,293 193,997 110,530 57,941 113,137 71,222 47,965 54,612 74,926 55,845 47,988 67,282 72,979 44,970 15,885 33,770 14,537 11,455 120

93,820 48,036 10 11,187 26,777 3,180 6,917 23 728 


\title{
L'ENVOI.
}

\author{
By Leverett H. Mesick.
}

All things must come to a halt-it were well they did not overstay their time. The hero of "The Master Planter" has now little need of further chronicling here. He has become so firmly established in the life of Hawaii, socially and industrially, that the daily history of the Island Territory is but a recount, in some phase, of him and his. For decades sugar-producing has been the industrial life-blood of the Islands, and, while other industries have come to the fore of late that may create "The Pineapple King," or "The Sisal Sovereign," or "The Tobacco Plutocrat," or "The Coffee Captain" in some of the nearby days, still the sugar cane fields are the mainstay, directly or indirectly, of a majority of the people here.

And still other great things are in store for Hawaii. After many years of talk and argument and citation by keenvisioned individuals, the United States Government has become convinced that Hawaii can and must be made the most strategic military post in the world. And acting upon this conviction, at this writing, fall of 1910, work is well under way for the impregnable fortification of the Island of Oahu, and the building at Pearl Lochs of an immense drydock and naval works, which will be the largest plant of the kind in the world. The Island of Oahu will be a great naval and military base, for, besides ships of war and defensive forts, there will be an acclimatization station here, where many thousands of soldiers will be seasoned for work in any part of the tropics to which United States troops may be sent. And then the opening of the great Panama Canal will bring $\mathrm{Ha}$ waii into focus as an indispensable rest and supply station for the ever-increasing trans-Pacific travel and traffic

And now, dear reader, have you guessed who Breed, alias "Kansas," really is? for you must be aware that the name Breed does not occur in the Directory of the Hawaiian Islands, much less in the list of men who have been prominent in the development of the sugar industry. No keener, broaderminded, more honorable or helpful men have ever favored any community than the cane planters and sugar makers and 
their scientific aides of Hawaii. At first thought some prominent plantation manager may be selected as the hero of this story, and again another individual, and yet another may be suggested. And these suggestions are all correct, for the man who did so much for the development of Hawaii is a composite character.

FINIS. 





\section{LIBRARY OF CONGRESS

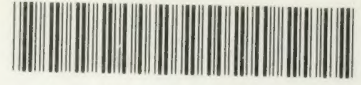 00027740601}

